\title{
Advanced glycation endproducts in multiple sclerosis
}

Citation for published version (APA):

Wetzels, S. M. W. (2019). Advanced glycation endproducts in multiple sclerosis. [Doctoral Thesis, Maastricht University, Universiteit Hasselt]. Maastricht University. https://doi.org/10.26481/dis.20190221sw

Document status and date:

Published: 01/01/2019

DOI:

10.26481/dis.20190221sw

Document Version:

Publisher's PDF, also known as Version of record

\section{Please check the document version of this publication:}

- A submitted manuscript is the version of the article upon submission and before peer-review. There can be important differences between the submitted version and the official published version of record.

People interested in the research are advised to contact the author for the final version of the publication, or visit the DOI to the publisher's website.

- The final author version and the galley proof are versions of the publication after peer review.

- The final published version features the final layout of the paper including the volume, issue and page numbers.

Link to publication

\footnotetext{
General rights rights.

- You may freely distribute the URL identifying the publication in the public portal. please follow below link for the End User Agreement:

www.umlib.nl/taverne-license

Take down policy

If you believe that this document breaches copyright please contact us at:

repository@maastrichtuniversity.nl

providing details and we will investigate your claim.
}

Copyright and moral rights for the publications made accessible in the public portal are retained by the authors and/or other copyright owners and it is a condition of accessing publications that users recognise and abide by the legal requirements associated with these

- Users may download and print one copy of any publication from the public portal for the purpose of private study or research.

- You may not further distribute the material or use it for any profit-making activity or commercial gain

If the publication is distributed under the terms of Article $25 \mathrm{fa}$ of the Dutch Copyright Act, indicated by the "Taverne" license above, 


\title{
Advanced glycation endproducts in multiple sclerosis
}

\author{
PROEFSCHRIFT
}

ter verkrijging van de graad van doctor aan de Universiteit Maastricht, op gezag van de Rector Magnificus, Prof. dr. Rianne M. Letschert,

en de graad van doctor in de Biomedische Wetenschappen aan de

Transnationale Universiteit Limburg/Universiteit Hasselt, op gezag van de Rector Prof. dr. Luc De Schepper,

volgens het besluit van het College van Decanen,

in het openbaar te verdedigen

op donderdag 21 februari 2019 om 14.00 uur in Maastricht

door

Suzan Maria Winand Wetzels 


\section{Promotores}

Prof. dr. C.G. Schalkwijk (Maastricht University)

Prof. dr. J.J.A. Hendriks (Universiteit Hasselt, België)

\section{Copromotores}

Dr. K. Wouters (Maastricht University)

Dr. T. Vanmierlo (Universiteit Hasselt, België)

\section{Beoordelingscommissie}

Prof. dr. J. Prickaerts (Voorzitter, Maastricht University)

Prof. dr. ir. E.A.L. Biessen (Maastricht University)

Prof. dr. V. Bito (Universiteit Hasselt, België)

Dr. A-M. van Dam (VU Medisch Centrum Amsterdam)

Prof. dr. N. Hellings (Universiteit Hasselt, België)

Prof. dr. H. Niessen (VU Medisch Centrum Amsterdam)

Financial support of Maastricht University and Hasselt University for the publication of this thesis is gratefully acknowledged 


\section{Table of contents}

Chapter 1 General introduction 5

Chapter 2 Methylglyoxal-derived advanced glycation endproducts are produced by activated astrocytes and accumulate in multiple sclerosis lesions

Chapter 3 Advanced glycation endproducts are increased in the animal model of multiple sclerosis but cannot be reduced by pyridoxamine treatment or glyoxalase 1

Addendum Advanced glycation endproducts in the cuprizone mouse model of multiple sclerosis

Chapter 4 Dietary methylglyoxal and advanced glycation endproducts accumulate in the central nervous system and prime towards a pro-inflammatory status

Chapter 5 Dietary methylglyoxal and advanced glycation endproducts do not aggravate disease progression in experimental autoimmune encephalomyelitis

$\begin{array}{lll}\text { Chapter } 6 & \text { Summary \& General discussion } & 105\end{array}$

$\begin{array}{lll}\text { Chapter } 7 & \text { Nederlandse samenvatting } & 123\end{array}$

$\begin{array}{lll}\text { Chapter } 8 & \text { Valorisation } & 129\end{array}$

$\begin{array}{ll}\text { Curriculum Vitae } & 139\end{array}$

$\begin{array}{ll}\text { Scientific output } & 141\end{array}$

$\begin{array}{ll}\text { Dankwoord } & 145\end{array}$

$\begin{array}{ll}\text { Abbreviations } & 151\end{array}$ 



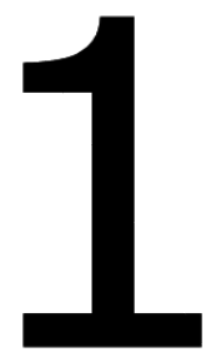

\section{General introduction}

Based on:

Methylglyoxal-Derived Advanced Glycation Endproducts in Multiple Sclerosis

Suzan Wetzels, Kristiaan Wouters, Casper G. Schalkwijk, Tim Vanmierlo*, Jerome J.A. Hendriks*

* These authors contributed equally to this work

Int. J. Mol. Sci. 2017 18(2), 421 


\section{General introduction}

\section{Multiple sclerosis}

The first documentation of multiple sclerosis (MS) dates from the $14^{\text {th }}$ century where the Dutch St. Lidwina van Schiedam developed acute illness and subsequently fell during ice skating on the frozen canal. However, it was the French neurologist, Jean-Martin Charcot (1825-1893) who linked the symptoms of MS with the pathological changes observed in post-mortem samples in 1868 describing them as "la sclérose en plaques" [1]. Charcot was the first to describe and draw detailed pictures of ventricular lesion expansion into the hemispheres. Moreover, he documented the process of demyelination describing it as "the destruction of the myelin cylinder" [2]. In addition to post-mortem research, Charcot was the first to diagnose a patient with MS [3]. His observations were the beginning of decades of research investigating the etiology and pathology of MS.

\section{Clinical course}

MS is an inflammatory, demyelinating disease of the central nervous system (CNS) [4]. MS mainly manifests between the ages 20 - 40, affecting women twice as often as men [5]. Usually, patients experience an acute episode of inflammation or demyelination in the CNS which is called a clinical isolated syndrome (CIS) [6]. Not all patients will develop new symptoms after the first incident, but when new lesions and symptoms occur, the diagnosis MS can be made. The typical disease course, occurring in about $85 \%$ of MS patients, is relapsing-remitting (RR)-MS, in which there are episodes of acute neurological deficits (relapses) that result in disability with full recovery between relapses [7]. Sixty-five percent of the RR-MS patients enter the secondary progressive stage of MS (SP-MS) within 5 - 15 years after the initial diagnosis [8]. The SPMS phase is characterized by incomplete recovery between relapses and progression of the disease. Moreover, in this phase of the disease, the inflammation is reduced but the neurodegenerative component is more dominant leading to progressive disability as the CNS is unable to compensate for loss of function [9]. Fifteen percent of MS patients show a progressive course from onset of the disease without relapses and remission. These patients are categorized as primary-progressive MS (PP-MS) patients. MS patients show a wide variety of symptoms, such as visual disturbance, paresthesia, ataxia, and muscle weakness which is dependent on the damaged areas in the CNS [10].

\section{Diagnosis}

There is no simple diagnostic test to determine whether patients suffer from MS or another disease, resembling MS etiology. From 2001, MS was diagnosed using the McDonald criteria [11]. These criteria are based on 2 clinical attacks disseminated in both time and space. However, in 2010 these criteria were reevaluated to allow the diagnosis of MS after one clinical attack [12]. The diagnosis of MS is nowadays made based on several measurements including 
magnetic resonance imaging (MRI), cerebrospinal fluid (CSF) analysis and evoked potentials (EPs) [13]. MRI is an important tool to determine the location, size and number of lesions in the brain and spinal cord which are present in $95 \%$ of MS patients at diagnosis [14]. However, the presence of lesions on MRI images is not specific for MS [15]. In addition to MRI, CSF analysis is performed to determine the presence of immunoglobulin $G$ ( $\mathrm{IgG}$ ) oligoclonal bands. Oligoclonal bands are immunoglobulins, produced by activated B-cells, which are present in the CSF but absent in the serum of MS patients. Unfortunately, also the presence of oligoclonal bands is not specific for MS [16]. Finally, EPs are used as part of the diagnostic methods. EP measures the electric activity in the brain after stimulation of specific visual, auditory or sensory pathways. Disturbances in EP can indicate possible demyelinated areas [17]. Similar as MRI-detected lesions and oligoclonal bands in the CSF, positive outcome after EP testing is not exclusive for MS and also occurs in other diseases. This indicates the difficulty of diagnosing MS with one simple test. The combination of these tests will help the physician to determine whether there are lesions in the CNS, in at least two separate regions, that developed at different time points, which is typical for MS, to give a solid indication of the diagnosis.

\section{Genetic \& environmental factors}

MS is a complex disease. It is generally assumed that MS is triggered by environmental factors in genetically susceptible hosts. Family studies revealed the genetic component in MS and demonstrated a $20-33 \%$ family recurrence rate and an 10-12 fold risk increase in first degree relatives [6]. Several genes are associated with MS susceptibility, especially genes encoding for the major histocompatibility complex (MHC) also called human leukocyte antigen (HLA DRB1*1501, HLA DQA $1 * 0102$, HLA DQB1*0602), which are responsible for $50 \%$ of the genetic risk for MS [18]. Genome-wide association studies (GWAS) have linked over 200 other immune-related genes to MS risk including genes encoding the interleukin (IL)-17 receptor and IL-2 receptor, cytokines such as IL-12a and IL-12 $\beta$, and genes associated with co-stimulatory molecules including CD80, CD86 and CD37 [19]. In addition to genetic factors, there are environmental factors that can contribute to the development of MS such as active smoking [20], reduced levels of vitamin D [21] and infection with EpsteinBarr virus [22]. Reduced levels of vitamin D are linked with the geographic spread of MS, as these levels positively correlate with increasing latitude due to reduced exposure to sunlight which is necessary for vitamin $D$ production in the skin [23].

\section{Pathogenesis}

MS is an autoimmune disease of the CNS. The autoimmune response, which mainly involves autoreactive T-cells, B-cells, macrophages and CNS-resident microglia, is directed against CNS antigens [24]. Macrophages and microglia contribute to neuroinflammation and neurodegeneration by the secretion of proinflammatory mediators such as cytokines and chemokines, the degradation and 
phagocytosis of myelin, and presentation of myelin antigens to autoreactive Tcells and B-cells [24]. The interplay between the innate (e.g. macrophages and microglia) and the adaptive immune system at target locations is essential, as infiltrating T-lymphocytes require antigen presentation in order to be restimulated [25]. This leads to the secretion of pro-inflammatory cytokines and chemokines, thereby recruiting more T-cells, B-cells and monocytes to the CNS. $\mathrm{B}$-cells are the producers of auto-antibodies directed against CNS components [26]. These are often found in the CSF of MS patients and are used for diagnosis. Moreover, B-lymphocytes present antigen to T-cells and influence neuroinflammation by the secretion of pro- and anti-inflammatory cytokines [27, 28]. In addition to the cells of the immune system, astrocytes can also contribute to neuroinflammation since they exhibit functions that are similar to immune cells such as production of pro-inflammatory cytokines and chemokines [29].

During MS, an inflammatory response in the CNS leads to myelin degradation. There are two hypotheses for the role of immune cells in the development of lesions. First, a major hypothesis in MS pathology is that immune activation for a specific CNS antigen occurs in the periphery and is then relocated to the CNS, the so-called "outside-in hypothesis" $[30,31]$. In this case, the activation of immune cells, mostly CD4 ${ }^{+}$T-cells, is thought be a result of molecular mimicry in which cells are primed with a foreign antigen that resembles structures of autoantigens. The second, opposing, hypothesis states that an initiating event within the CNS, a primary infection or neuronal disturbances, causes activation of resident microglia, and is called the "inside-out hypothesis" [30]. This immune reaction in the CNS leads to recruitment of innate and adaptive immune cells from the periphery which will aggravate CNS inflammation. However, to this date the exact cause of MS remains unknown.

\section{Therapeutics in MS}

Despite the years of research, we are still unable to cure MS. However, there are treatment options available that aim to reduce the inflammatory component of the disease and hamper disease progression. These therapies are called diseasemodifying therapies (DMTs) and include oral medication, injectable medication and infused medication, all with their own advantages and drawbacks. Since these therapies are targeted at reducing inflammation, they are only effective when inflammation is present and are mostly prescribed to RR-MS patients.

First line therapies approved by the US Food and Drug Administration (FDA) and European Medicines Agency include interferon $\beta$ 1a (IFN $\beta$ 1a; Avonex ${ }^{\circledR}$, Rebif ${ }^{\circledR}$ ) and $1 \mathrm{~b}$ (IFN $\beta$ 1b; Betaseron ${ }^{\circledR}$, Extavia ${ }^{\circledR}$ ), glatiramer acetate (Copaxone ${ }^{\circledR}$ ), teriflunomide (Aubagio ${ }^{\circledR}$ ), dimethyl fumarate (Tecfidera ${ }^{\circledR}$ ) and alemtuzumab (Lemtrada ${ }^{\circledR}$ ). In the nineties, IFN $\beta$ and glatiramer acetate became available for MS patients. These therapies are injected subcutaneously or intramuscularly in case of Avonex ${ }^{\circledR}$. The exact mechanisms of action of IFN $\beta$ and glatiramer 
acetate are still not fully understood. IFN $\beta$ is thought to have beneficial antiinflammatory effects, decreasing pro-inflammatory cytokines, reducing $\mathrm{MHC}$ expression, shifting the $\mathrm{T}$-cell response towards $\mathrm{Th}_{2}$, inducing $\mathrm{T}_{\text {reg }}$ and limiting $\mathrm{T}$ cell crossing across the blood-brain barrier (BBB) [32, 33]. Glatiramer acetate induces an anti-inflammatory $\mathrm{Th}_{2}$ response which may be modulated via the inhibition of antigen presenting cells [34, 35]. More recently, the FDA approved the first oral therapeutics which are teriflunomide and dimethyl fumarate but also alemtuzumab which is administered via infusion. Teriflunomide inhibits a mitochondrial enzyme, dihydro-orotate dehydrogenase, which is necessary in the production of de novo pyrimidine. Pyrimidine is essential for DNA synthesis as it is one of the major components of the DNA. Interfering with de novo pyrimidine synthesis leads to a disruption and eventually a hold in DNA synthesis. This reduces lymphocyte proliferation, as $\mathrm{T}$ - and B-cells proliferate upon activation, and limits inflammation in MS [36, 37]. The exact mechanisms of dimethyl fumarate remain unclear but it is thought to decrease lymphocyte counts, shifting immune cells towards an anti-inflammatory phenotype and activate pathways involved the response against oxidative stress [38]. Lastly, alemtuzumab is a monoclonal antibody that induces cell death of CD52 ${ }^{+} \mathrm{T}$ - and B-cells, thereby interfering with the immune response [39]. When these first line therapies do not give adequate results, MS patients can switch to second line therapies.

Second line therapies include fingolimod (Gilenya ${ }^{\circledR}$ ), natalizumab (Tysabri ${ }^{\circledR}$ ), rituximab (Rituxan ${ }^{\circledR}$ ), ocrelizumab (Ocrevus ${ }^{\circledR}$ ), and mitoxantrone (Novantrone ${ }^{\circledR}$ ). These therapies bring higher safety risks [40]. Fingolimod is an oral second line therapy that is directed at the sphingosine-1-phosphate receptor present on immune cells and leads to trapping of these immune cells in lymphoid tissues [41]. However, the use of Fingolimod can induce side effects such as bradyarrhythmias [40]. Natalizumab, rituximab and ocrelizumab are monoclonal antibodies that are all administered via infusion. Natalizumab binds to very late antigen-4 which is present on activated leukocytes and monocytes thereby preventing infiltration in the CNS [42, 43], whereas rituximab and ocrelizumab target $\mathrm{CD}^{2} 0^{+} \mathrm{B}$-cells inducing cell death $[44,45]$. Ocrelizumab is the only FDA-approved therapy for PP-MS patients [46]. Natalizumab treatment is associated with progressive multifocal leukoencephalopathy due to JC virus infection [40], a severe side effect in which oligodendrocytes are affected, leading to more demyelination [47]. Finally, the chemotherapeutic agent mitoxantrone intercalates with DNA leading to reduced DNA repair. This results in reduced numbers of lymphocytes including T-cells, B-cells and macrophages [48]. However, this therapy has severe side effects such as cardiotoxicity and the development of acute leukaemia which limits its use [49,50].

In addition to these treatments, a more radical approach in MS therapy is evolving: autologous hematopoietic stem cell transplantation (AHSCT). The procedure of AHSCT relies on the elimination of the destructive immune system 
followed by immune reconstitution with the patient's own hematopoietic stem cells which are isolated from peripheral blood [51], thereby resetting their immune system [52]. In 1995, the first 15 MS patients underwent the procedure in a pilot study demonstrating that AHSCT was feasible in MS patients [53]. To this date, it has resulted in phase I, II and III clinical trials to investigate the efficacy of AHSCT compared to the available therapeutic options. In the phase II ASTIMS trial, the efficacy of AHSCT was determined in aggressive RRMS patients and SPMS patients compared to mitoxantrone [54]. Although only 21 patients participated in the trial, the number of new MRI lesions developing over the course of 4 years was 79\% lower in patients that underwent AHSCT compared to patients receiving mitoxantrone. Moreover, the phase II HALT-MS trial revealed in highly active RRMS patients that $69.2 \%$ remained event-free without relapses, new MRI lesions and disability progression after 5 years of follow-up [55]. Currently, there are still clinical trials investigating AHSCT as a treatment option for MS patients. However, it must be noted that this therapy is not without any risks. The toxicity of the drugs that are used to increase the amount of stem cells in the blood and to eliminate the patient's destructive immune system is high. The mortality rate of the procedure is estimated around $1-2 \%$ and the procedure can lead to adverse side effects such as neutropenic fever (50\% of patients), infectious diseases, and the induction of secondary autoimmune diseases [51]. Therefore, this treatment option is limited to MS patients who experiences frequent relapses, indicating active inflammatory processes, and do not respond to any of the immunomodulatory therapies.

\section{Animal models of MS}

It has been stated above that MS is a complex disease in which many factors, genetic and environmental, play an important role. Therefore, it is difficult to develop an animal model that displays the entire spectrum of heterogeneity of MS [56]. The most-studied animal model of MS is the experimental autoimmune encephalomyelitis (EAE). EAE is induced after sensitization to CNS myelin proteins such as myelin oligodendrocyte glycoprotein (MOG), myelin basic protein (MBP) and proteolipid protein (PLP) [56]. Depending on the genetic background of the experimental animal, the myelin antigen and the immunization method, different disease courses and pathology will develop. Immunization of $\mathrm{C} 57 \mathrm{BI} / \mathrm{J}$ mice with $\mathrm{MOG}_{35-55}$ peptide leads to the induction of a chronic EAE model [57], whereas immunization of SJL/] mice with PLP induces a relapsing remitting EAE model [58]. The induction of EAE is done in both female and male mice using one of the above described myelin antigens, emulsified in complete Freund's adjuvant (CFA) together with intraperitoneal injections of pertussis toxin to boost the immune response. In addition to the induction of EAE with CNS antigens, EAE can be induced by the adoptive transfer of encephalitogenic T-cells into recipient mice [59]. Both induction methods result in paralysis starting from the tail and gradually expanding upwards [60, 61]. Besides paralysis also the disease pathology shows many similarities to MS. Moreover, the EAE model results in infiltration of immune cells, demyelination, 
remyelination and the production of IgG in the CSF, all similar to the processes in MS patients [62]. However, there are also limitations of the EAE model. In $E A E$, the induction is done using known CNS antigens whereas the exact trigger of MS remains unknown. Moreover, lesion development in the EAE model is mostly restricted to the spinal cord while in most MS patients lesion develop mainly in the brain [63]. There are also therapies that were proven to be successful in the EAE model but failed in MS patients [64-66]. This indicates that, even though the EAE model is one of the most used animal models of MS, translation to MS patients must be done with care.

There are also other models that can be used to study specific aspects of MS. To study de- and remyelination, the toxic-induced cuprizone or lysolecithin model can be used [67]. Cuprizone is a copper chelating reagent that is mixed in the standard diet of the animals and induces specific oligodendrocyte cell death resulting in demyelination [56]. Removing the cuprizone from the diet will induce the formation of new oligodendrocytes from the oligodendrocyte precursor cells leading to remyelination. Lysolecithin, an phospholipase A2 activator, is a component that is locally injected into the CNS to induce demyelination due to its toxic effect on myelin [68]. These models do not reflect MS, but can be used to study specific pathological and regenerative aspects of the disease.

\section{Advanced glycation endproducts}

Advanced glycation endproducts (AGEs) are increased in inflammatory diseases such as diabetes [69, 70], atherosclerosis [70, 71], obesity [72] and nonalcoholic steatohepatitis [73], but also neurodegenerative diseases such as Alzheimer's disease [74] and Parkinson's disease [75]. Gaens et al. revealed that the AGE $\mathrm{N} \varepsilon$-(carboxymethyl)lysine (CML) is significantly increased in liver [73] and visceral adipose tissue [72] of obese patients compared to controls, which was related to an increase in pro-inflammatory makers and thus inflammation. In Alzheimer's disease, $\beta$-amyloid peptide depositions and neurofibrillary tangles are affected by glycation $[76,77]$. Moreover, Dalfó et al. have shown that glycation is present in the cerebral cortex, amygdala and substantia nigra of healthy subjects and that these are increased in Parkinson's disease patients [75]. Also, AGEs are increased in the plasma and brain of MS patients [78, 79]. Accumulation of AGEs in the plasma and CNS of MS patients may contribute to neuroinflammation and the progression of MS.

\section{Formation of AGEs}

AGEs are stable endproducts of a non-enzymatic glycation reaction. The formation of AGEs (the Maillard-reaction) starts with the reaction of sugar aldehydes with the $\mathrm{N}$-terminus of free-amino groups of proteins to form a socalled Schiff base [80]. Rearrangements of the instable Schiff base leads to the formation of Amadori products. A small subset of Amadori products will undergo further irreversible reactions leading to the formation of AGEs $[80,81]$. 
Frequently formed AGEs are CML, $\mathrm{N}^{\varepsilon}$-(1-carboxyethyl)lysine (CEL), and pentosidine. The formation of AGEs via the Maillard-reaction is a slow process taking weeks. This reaction can be speeded by heating and is therefore an important process during the preparation and processing of food. Cooking methods, such as baking and frying, result in high dietary AGE levels. Dietary AGEs are responsible for the brown colour on food and contribute to flavour [82]. It is known that dietary AGEs are associated with elevated plasma and urine levels of AGEs [83-85], suggesting that dietary AGEs are absorbed from the nutrition and contribute to the in vivo AGE pool.

In addition to dietary AGEs and the slow Maillard-reaction, it is becoming clear that the majority of AGEs in vivo are mainly formed in a fast reaction of dicarbonyl compounds such as methylglyoxal (MGO) and glyoxal (GO) with proteins [80].

\section{Formation and detoxification of MGO}

MGO is produced as a byproduct of glycolysis via the fragmentation of triosephosphates glyceraldehyde-3-phosphate (GAP) and dihydroxyacetone phosphate (DHAP) as shown in figure $1[86,87]$. In addition, GO can be created directly from glucose via a retro-aldol condensation reaction and indirectly via GAP [88]. Moreover, reactive dicarbonyl compounds can be formed as a result of lipid peroxidation creating so called advanced lipoxidation endproducts (ALES). Lipid peroxidation of polyunsaturated fatty acids occurs under circumstances with increased oxidative stress and high amounts of reactive oxygen species (ROS). This will lead to the formation of lipid peroxides that undergo fragmentation to produce reactive carbonyl compounds such as malondialdehyde (MDA) and 4-hydroxynonenal (HNE), but also the dicarbonyl compounds MGO, and GO (Figure 1) [89].

Since there is a great variety in free-amino groups in proteins, lipids and nucleic acids, AGEs and ALEs represent a diverse and very large group of modifications. Interaction of MGO with arginine leads to the formation of specific AGEs $\mathrm{N}^{\delta}-(5-$ hydro-5-methyl-4-imidazolon-2-yl)-ornithine (MG-H1) and tetrahydropyrimidine (THP) [90]. In addition, MGO and GO can react with lysine to form CEL and CML, respectively. Since $M G O$ and $\mathrm{GO}$ are formed during glycolysis and during lipid peroxidation, CML and CEL can be regarded as both AGEs and ALEs [80].

Intracellular accumulation of reactive carbonyls MDA and HNE and dicarbonyl compounds MGO and GO, is highly toxic because these compounds are potent glycating agents [86]. To reduce the toxic effects of reactive (di)carbonyl compounds and the formation of AGEs/ALEs, the body has several defence systems such as glyoxalase, aldose reductase, aldehyde dehydrogenase and carbonyl reductase pathways [86, 88]. The glyoxalase system is the main defence system to reduce the toxicity of reactive dicarbonyl compounds. MGO, and to a lesser extent GO, is detoxified by the glyoxalase system, a ubiquitous enzymatic pathway present in the cytoplasm [87]. There are two enzymes 
responsible for the detoxification: glyoxalase-1 (Glo-1) and glyoxalase-2 (Glo2). First $\mathrm{MGO}$ is converted to $\mathrm{S}$-Lactoylglutathione by Glo-1 which uses glutathione (GSH) as a cofactor (Figure 1). Subsequent, S-Lactoylglutathione is metabolized to D-lactate by Glo-2. GSH gets recycled during this last step in the process, making it available for new detoxification of MGO. The conversion of MGO by Glo-1 is important because this is the rate-limiting step and SLactoylglutathione is not as toxic to cells as MGO.

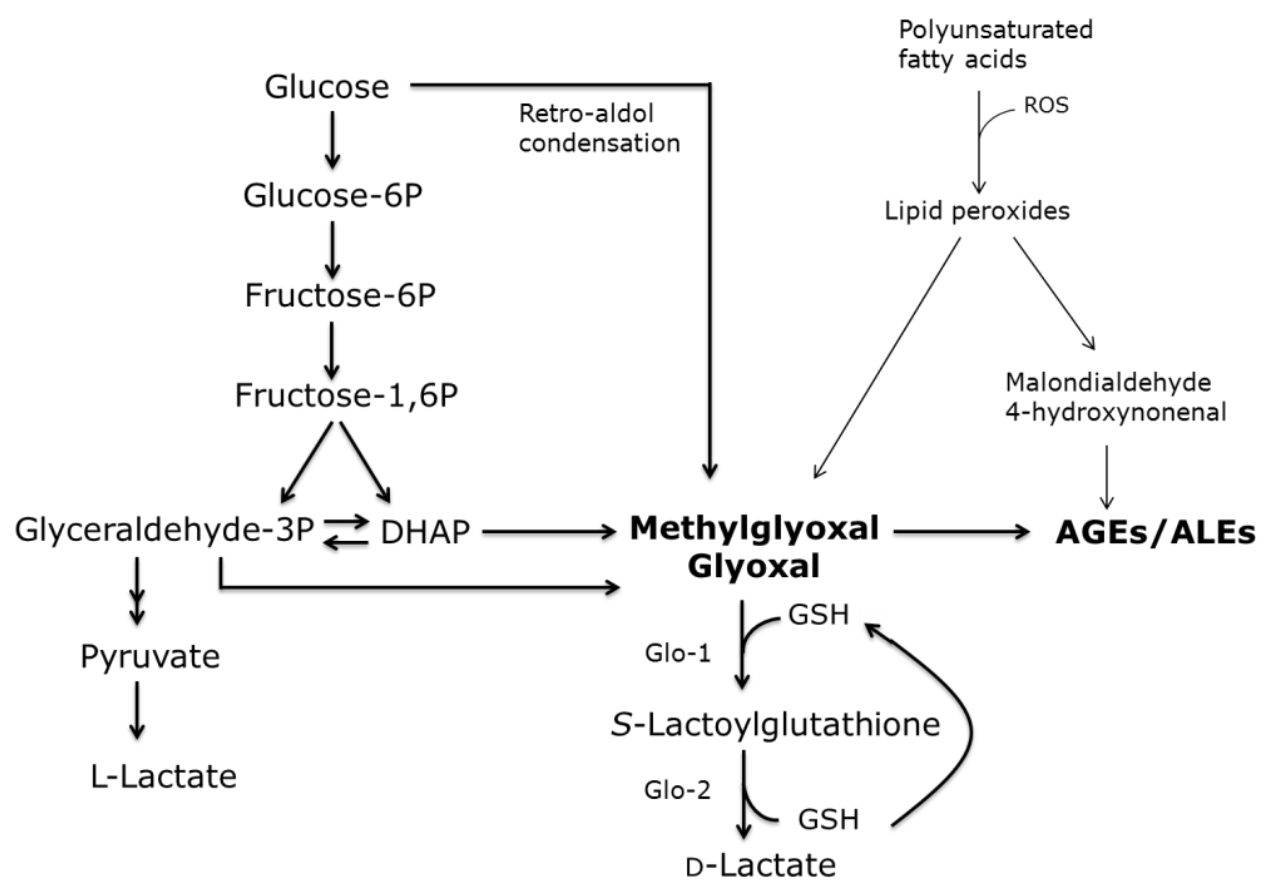

Figure 1.1. Formation of reactive dicarbonyl compounds and AGEs/ALEs via glucose and lipid intermediates. During glycolysis, glucose is converted into pyruvate and subsequently into lactate. Fragmentation of glyceraldehyde-3-phosphate (GAP) and dihydroxyacetone phosphate (DHAP) leads to the formation of methylglyoxal and glyoxal. In addition to glycolysis, lipid peroxidation of polyunsaturated fatty acids leads to the formation of lipid peroxides that can undergo fragmentation resulting in the formation of malondialdehyde, 4-hydroxynonenal, methylglyoxal, and glyoxal. Moreover, glyoxal can be directly created from glucose, via a retro-aldol condensation reaction. Incubation of these highly reactive compounds with proteins, lipids and nucleic acids, leads to the fast formation of advanced glycation endproducts (AGEs) and advanced lipoxidation endproducts (ALEs). Methylglyoxal and glyoxal are detoxified via the glyoxalase system. First, methylglyoxal and glyoxal are converted to S-Lactoylglutathione by Glo1, which uses glutathione as a cofactor. Subsequently, S-Lactoylglutathione is metabolized to D-lactate by Glo-2. Glutathione gets recycled during this last step in the process. 


\section{Biological effects of MGO and AGEs}

MGO can have several direct effects. $M G O$ increases oxidative stress by inducing superoxide $\left(\mathrm{O}_{2}^{-}\right)$, hydrogen peroxide $\left(\mathrm{H}_{2} \mathrm{O}_{2}\right)$ and peroxynitrite $\left(\mathrm{ONOO}^{-}\right)$but also by decreasing antioxidants and their mechanisms [91]. Moreover, cultured neuronal cells upregulate IL-1 $\beta$ expression and secretion after MGO stimulation [92], thereby contributing to inflammation. MGO is also able to induce apoptosis by increasing the $\mathrm{Bax} / \mathrm{BCl}-2$ ratio and activation of caspase- 9 and caspase-3, promoting the mitochondrial apoptosis pathway [93]. In addition to these direct effects, MGO is a potent glycating agent resulting in the formation of AGEs which have biological effects by three general mechanisms. First, protein function can be altered by intracellular glycation of proteins resulting in distorted cell function [94]. Second, the modification of extracellular matrix proteins by AGEs leads to altered interactions between the cells and proteins [82, 95]. The third mechanism is the binding of AGEs to a variety of cell surface receptors leading to the activation of downstream signalling pathways. The best described receptor is the multi-ligand receptor for advanced glycation end-products (RAGE). This receptor not only binds AGEs but also amyloid proteins, highmobility group B (HMGB), Mac-1 and S100 proteins $[96,97]$, and is thought to be expressed on a variety of cell types involved in MS such as, monocytes/macrophages, T-cells, astrocytes and endothelial cells. The binding of ligand to RAGE leads to increased intracellular oxidative stress and activation of NF-kB, which increases the production of pro-inflammatory cytokines like IL$1 a$, IL-6 and TNFa $[81,95]$. However, there are more receptors known that bind AGEs such as AGER1 [81, 96] which is also expressed on monocytes/macrophages, T-cells, endothelial cells and smooth muscle cells. AGER1 is a type I transmembrane protein that is supposed to facilitate AGE turnover by mediating uptake, degradation and removal of AGEs [82]. Moreover, AGER1 activation reduces the effects of RAGE signalling by deacetylation of NF$K B$ via sirtuin-1 [82]. Therefore, AGER1 contributes to an anti-inflammatory status as its signalling pathway leads to a decrease in oxidative stress and proinflammatory cytokines.

\section{Advanced glycation endproducts in multiple sclerosis}

There are several studies that have shown differences in AGE levels in MS patients compared to healthy controls. Moreover, there is evidence that AGEs contribute to the disease progression in MS. In the next part, we will summarize the literature describing AGE levels, pathogenic effects of AGEs and the involvement of the glyoxalase system, glycolysis, lipid peroxidation and RAGE in MS.

\section{Alterations in AGE levels in MS}

Previous research demonstrated that AGEs are increased in the plasma and brain of MS patients [78, 79]. Sternberg et al. investigated the diagnostic potential of plasma AGEs, specifically CML and CEL, in MS patients and healthy controls. They showed that CEL plasma levels, but not CML levels, are higher in 
MS patients compared to healthy controls and that DMTs reduced CEL plasma concentrations [78]. Furthermore, the presence of CML and RAGE was determined in paraffin-embedded brain sections of four relatively young MS patients [79]. It was found that CML and RAGE are expressed in astrocytes and macrophages within and in close proximity of MS lesions. These studies have shown that AGEs are present in the brain and plasma of MS patients. However, it is unclear whether the increase in AGE levels in the plasma of MS patients reflects the AGE levels in the CNS of MS patients.

\section{The effects of AGEs on key cells in MS development and progression}

MGO is a potent glycating agent, leading to increased levels of MGO-derived AGEs which can exert their effects via their receptor RAGE. Key cells in MS development such as microglia, astrocytes and endothelial cells (in the bloodbrain barrier), express RAGE making them possible targets for AGEs. It can be hypothesized that MGO-derived AGEs act as accelerators of MS lesion pathology by inducing a detrimental positive feedback loop, as illustrated in figure 2. It has been reported that activation of microglia by AGEs leads to an increased expression and secretion of pro-inflammatory cytokines, such as TNFa, IL-1 $\beta$ and IL-6 [98-100]. Moreover, stimulation with AGEs leads to increased levels of RAGE $[100,101]$, creating a positive feedback loop that promotes inflammation. In addition to microglia, astrocytes are abundantly present in the CNS and also express RAGE making them susceptible for AGE-RAGE activation. Indeed, it is reported that stimulation of astrocytes with glucose-modified bovine serum albumin, which can be regarded as AGEs, leads to increased TNFa and IL-6 secretion [102]. Furthermore, a glucose rich environment, which is present in the CNS of MS patients, induces a pro-inflammatory phenotype in astrocytes which contributes to neuroinflammation [103].

The BBB is required to maintain homeostasis within the CNS and block the entry of toxic stimuli, infectious agents and peripheral immune cells. The BBB consist of endothelial cells that are attached to each other by tight junctions. These tight junctions, comprised of different tight junction proteins such as occludins and claudins, restrict the passive influx of molecules and cells into the CNS [104]. Endothelial cells of the BBB are affected when stimulated with AGEs leading to loss of tight junction protein expression and thus increasing the permeability of the BBB $[105,106]$. In addition, endothelial cells secrete proinflammatory cytokines that contribute to inflammation. Furthermore, glycation of the underlying matrix proteins was shown to lead to increased BBB permeability [105]. Besides endothelial cells, astrocytes and pericytes are also present supporting the BBB. Astrocytes cover the abluminal side of the capillaries in the BBB with end-feet projections and support BBB integrity [107]. As mentioned above, AGE-activated astrocytes and microglia can induce the production of pro-inflammatory cytokines and induce oxidative stress. It has been known that pro-inflammatory cytokines such as TNFa, IL- 6 and IL-1 $\beta$, and free radicals secreted by surrounding astrocytes can impair BBB function [108]. 
In addition, AGE-activated astrocytes increase the production of vascular endothelial growth factor and decrease the production of glial cell line-derived neurotrophic factor also contributing to an increased permeability of the BBB [109]. This could suggest that, in addition to the direct effect of AGEs on the BBB by binding to RAGE on endothelial cells, AGEs could have a potential indirect effect on BBB function by the activation of surrounding astrocytes and microglia. Taken all these results together, we can hypothesize that AGEs act as accelerators of MS lesion pathology by inducing a pro-inflammatory phenotype in microglia and astrocytes. This also leads to increased RAGE expression, which can act as a positive feedback loop by inducing more pro-inflammatory mediators. In addition, AGEs disrupt BBB function by direct AGE-RAGE activation or by indirect effects of activated microglia and astrocytes, resulting in increased infiltration of peripheral immune cells into the CNS, contributing to neuroinflammation and neurodegeneration.

\section{The glyoxalase system in MS}

The major precursor in the formation of AGEs, MGO, and to a lesser extent GO, can be detoxified by the glyoxalase system. As mentioned before, this system uses GSH as a cofactor, which is reused in the glyoxalase system as D-lactate is formed. In the CNS, the level of GSH is maintained by active intracellular GSH synthesis originating from astrocytes, but also from neurons [110]. In addition to the de novo synthesis, GSH can be recycled by glutathione reductase which converts the oxidized form of glutathione (GSSH) to the reduced form (GSH). In 2002, Calabrese et al. determined the amount of GSH in CSF samples of MS patients with the NADPH-dependent GSSG reductase method, revealing significantly decreased GSH in the CSF of these patients [111]. Moreover, Choi et al. developed a method to non-invasively measure GSH in vivo using MRI and found that GSH in the fronto-parietal area in the brain was significantly decreased in SP-MS patients compared to controls [112, 113]. The decrease in GSH concentration in MS patients may limit the detoxification of MGO by the glyoxalase system and this leads to accumulation of MGO in the cells, ultimately leading to an increase in MGO-derived AGEs. In addition to GSH availability, Sidoti et al. determined the frequency of the A111E polymorphism present in the Glo-1 gene as this particular polymorphism is known to have decreased detoxification capacity [114]. The frequency of the EE genotype was significantly increased in RR-MS patients compared to controls (59.8\% vs. $49.3 \%$, $\mathrm{p}<0.0001$ ) [115] suggesting that decreased Glo-1 activity can contribute to increased MGO-derived AGE levels in MS patients compared to controls. 


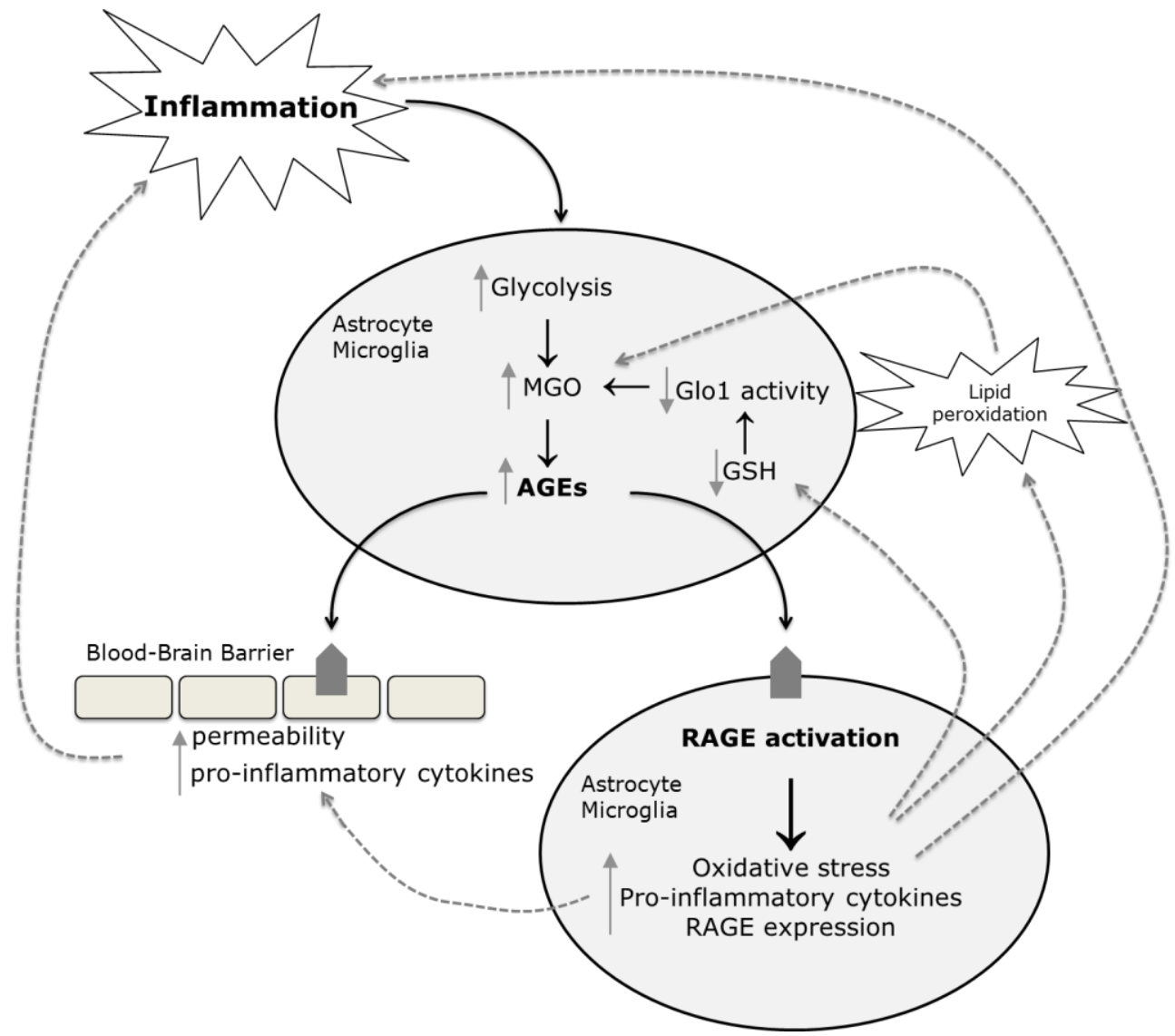

Figure 1.2. Schematic overview of the effects of methylglyoxal (MGO) on key cells in MS development. The inflammatory environment in the central nervous system (CNS) during MS leads to an increase $(\uparrow)$ in glycolysis in astrocytes and microglia. This induces $(\uparrow)$ the production of MGO and subsequently, AGEs. AGEs activate RAGE, which is present on astrocytes, microglia and endothelial cells, leading to increased oxidative stress, the production of pro-inflammatory cytokines and increased RAGE expression. Moreover, the BBB is affected by AGEs, leading to a loss of tight-junction proteins and thereby increasing permeability. Several positive feedback loops (dashed lines) may further stimulate the inflammatory response and increase the AGE levels in the CNS. The upregulation of RAGE upon its activation leads to an increased pathway activation and thus, oxidative stress and pro-inflammatory cytokines. Moreover, the production of proinflammatory cytokines contributes to the inflammatory status of the CNS. In addition, oxidative stress depletes ( $\downarrow$ ) glutathione (GSH), leading to decreased ( $\downarrow$ ) Glo1 activity, and stimulates lipid peroxidation, all of which contribute to the production of MGO, among others. The production of oxidative stress and pro-inflammatory cytokines in astrocytes that support the BBB can also contribute to an impairment of BBB function. $\uparrow$ grey upward arrow indicates increased production, $\downarrow$ grey downward arrow indicates decreased production and/or activity. 


\section{Increased glycolysis as an underlying mechanism for the formation of MGO-derived AGEs in MS}

The formation of AGEs via reactive dicarbonyl compounds mainly occurs in highly metabolic active cells which rely on glycolysis such as macrophages [116], microglia [117] and astrocytes [118-120]. Already in 1962, Karnovsky reported that phagocytosis leads to increased glycolysis in macrophages [121]. This implicates that in MS glycolysis is increased in phagocytes after uptake of myelin. Supporting this, Bogie et al. revealed using micro-array analysis of myelin treated macrophages that genes involved in glycolysis are induced [122] which likely results in the formation of AGEs in myelin containing macrophages.

Glucose is the main energy source of the brain where the energy requirements are high [123]. Nijland et al. investigated the distribution of specific glucose transporters in brain tissue of MS patients and non-neurological controls and found that glucose transporter 1 (GLUT1) and 4 (GLUT4) are increased in MS lesions [124]. GLUT1 is expressed in the brain microvasculature which ensures transport of glucose over the BBB and uptake of glucose by astrocytes [125]. GLUT4 is expressed on astrocytes and endothelial cells. It is known that demyelinated axons require more energy to maintain proper conduction of signals [126]. Therefore, an upregulation of nutrient transporters within MS lesions and increased glycolysis is necessary. Indeed, previous studies have revealed that MS patients have an increased glucose and lactate metabolism within lesions in the CNS which was observed with positron emission tomography and magnetic resonance spectroscopy $[127,128]$. The energy needed for signalling processes such as postsynaptic and action potentials, comes mainly from astrocytes, featured by a high glycolytic rate [118-120]. In addition to astrocytes, oligodendrocytes also appear to be glycolytic since the glycolytic activity is higher in white matter which consists of high numbers of oligodendrocytes compared to grey matter [129]. Funfschilling et al. proposed a hypothetical model in which glucose is used for ATP generation and serves the synthesis of myelin lipids at the onset of myelination [130]. Moreover, it is also suggested that in post-myelinated oligodendrocytes glycolysis is essential for survival. These data indicate that in MS not only the astrocytes but also oligodendrocytes are a potential source of glycolysis-derived reactive dicarbonyl compounds and thus of AGEs.

\section{Increased lipid peroxidation as an underlying mechanism for the formation of MGO-derived AGEs in MS}

In addition to glycolysis-derived formation of AGEs, AGEs are also formed during lipid peroxidation via the formation of reactive carbonyls MDA and HNE and dicarbonyl compounds, such as MGO and GO. The formation of lipid-derived AGEs is initiated by ROS (Figure 1) [89]. ROS are highly reactive small molecules that have an unpaired electron and have the ability to give rise to new free radicals [131]. ROS production can be rapidly increased due to oxidative phosphorylation in mitochondria, phagocytosis and enzymatic reactions which 
catalyse oxidases [132]. Under physiological conditions, concentrations of ROS remain low as a result of anti-oxidative mechanisms which include enzymatic reactions (superoxide dismutase and catalase) and non-enzymatic molecules (vitamin C, vitamin E, GSH). However, the CNS is sensitive to oxidative stress and the production of ROS due to the high rate of oxygen utilization and a relatively poor anti-oxidant defence system [133]. In addition, immune cells are a great source of ROS. During MS, activated microglia and infiltrated monocytederived macrophages accumulate in the CNS. Both microglia and macrophages produce large quantities of ROS [134]. A recent study from Guan et al. showed that MS patients have increased levels of the lipid peroxidation marker 8-isoPGF2a in their urine compared to healthy controls, indicating that lipid peroxidation is increased [135]. Moreover, the levels of urinary 8-iso-PGF2a corresponded with MS disease severity. Since the CNS is rich in polyunsaturated fatty acids, an increased amount of lipid peroxides can be formed due to lipid peroxidation. Van Horssen et al. compared the oxidative damage in MS lesions to normal appearing white matter (NAWM) and healthy controls [136]. Data from this study revealed that oxidative damage to proteins, nucleotides as well as lipids is increased in MS lesions compared to NAWM and controls. Furthermore, this oxidative damage was mostly found in hypertrophic astrocytes and phagocytic macrophages in active lesions [136]. Wang et al. revealed that MDA, a reactive carbonyl compound which is able to induce ALEs, is elevated in RR-MS patients [137]. The results from the above studies show that oxidative stress and lipid peroxidation are increased in MS patients. This may lead to an increased MGO, and subsequently AGE production in MS patients.

\section{Receptors for AGEs in MS}

RAGE is expressed on various cell types that are involved in MS. Andersson et al. determined that RAGE was upregulated in active MS lesions and in CNS lesions in EAE [138]. In 2003, Yan et al. examined the role of RAGE during EAE development and in MS [139]. It was shown that RAGE immunoreactivity is increased in brain samples from MS patients, especially in mononuclear phagocytes and $\mathrm{CD}^{+}{ }^{+} \mathrm{T}$-cells. This was confirmed in the spinal cord tissue of EAE mice. There is also experimental evidence that RAGE contributes to the disease progression of MS. Treatment of EAE mice with SRAGE, the cleaved variant of RAGE which prevents activation of membrane-bound RAGE [140], or specific RAGE blocking antibodies reduced disease severity compared to controls, suggesting that the activation of RAGE by ligands is involved during EAE. In contrast, Liliensiek et al. found that full body RAGE deficiency (RAGE ${ }^{-/}$) did not affect EAE disease severity [141]. However, cell specific overexpression of RAGE on hematopoietic and endothelial cells led to a significant increase in EAE severity compared to wild type controls. This suggests that RAGE expression on immune and endothelial cells is involved in the perpetuation but not in the initiation of neuroinflammation [141]. These data, showing no protective effect of full body RAGE deficiency during EAE development, are in contrast with the data of Yan et al, who revealed that treatment with SRAGE reduces disease 
severity. There are multiple explanations as to why these studies show contrasting results. One could speculate that there is a difference in the peripheral effects of RAGE, which are mainly blocked by SRAGE, compared to the full body of RAGE deficiency. Moreover, there may be a difference in the cell types affected by RAGE deficiency and treatment with sRAGE or RAGE blocking antibodies. Therefore, more experimental research needs to be conducted to obtain conclusive results about the role of RAGE during EAE and neuroinflammatory responses in general.

Interestingly, Sternberg et al. showed that the percentage of RAGE positive monocytes and T-cells was significantly increased in MS patients [142]. While membrane-bound RAGE was increased, sRAGE was decreased in MS patients and inversely related with the disability of the patient indicating that the receptor is involved in MS progression and can be used as a biomarker [143]. The increase of RAGE positive monocytes and T-cells in MS patients can lead to a more pro-inflammatory phenotype of these cells. In addition, SRAGE has therapeutic potential as it prevents the activation of RAGE which is necessary for the perpetuation of EAE.

Several polymorphisms for RAGE have been described including -429 T/C, -407 to 345 deletion, $-374 \mathrm{~T} / \mathrm{A},+20 \mathrm{~T} / \mathrm{A}$ and a substitution of Glycine with Serine at amino acid 82 (G82S) [144, 145]. In 2009, Tiszlavicz et al. found that the -374 T/A polymorphism was different between the MS patients $(n=168)$ and healthy controls $(n=136)$ in a Hungarian population, leading to a higher frequency of the $\Pi$ genotype in MS patients [146]. Although the frequency of the G82S polymorphism was not significantly different in Tiszlavicz's Hungarian population, $\mathrm{Li}$ et al. showed that the odds ratio of the G82S polymorphism is significantly different in a Chinese study cohort comparing MS patients ( $\mathrm{n}=$ 144 ) with healthy controls $(n=155)$ with a higher frequency of 825 in MS patients [147]. Although these two studies revealed differences in RAGE polymorphisms in MS patients compared to controls, GWAS could not confirm these polymorphisms in large cohorts. Moreover, the relative small sample is likely not representative for the entire population. Therefore, as GWAS did not reveal these polymorphism is a large population ( $n=14,498$ MS patients, $n=$ 24,091 healthy controls), the results concerning these RAGE polymorphisms should be interpreted with caution.

As described above, RAGE is a multi-ligand receptor which can bind HMGB1 and S100 proteins among others [96, 97]. It has been shown that HMGB1 is increased in the serum of RR-MS patients and in DMT-naïve MS patients [148, 149]. Moreover, several studies described the therapeutic potential of HMGB1 neutralizing antibodies in the EAE model. HMGB1 was elevated in the serum of mice subjected to EAE and blocking HMGB1 with neutralizing antibody resulted in reduced disease severity [150-152]. In addition to HMGB1, an alternative RAGE ligand S100b is also increased in the serum and CSF of MS patients [153- 
155]. Although mitoxantrone was able to decrease S100b levels [154], S100b levels in PP-MS patients were not associated with disease progression [156]. Taken together, it could be suggested that RAGE activation is present in MS, however, whether this is AGE-mediated remains to be elucidated.

In addition to RAGE, more receptors able to bind AGEs are of interest. One of these receptors is AGER1. We can only speculate about the function of AGER1 in MS. This AGE receptor ameliorates the negative effect of the AGE-RAGE axis by suppressing NF-KB activity [157] and thereby reduces the production of proinflammatory cytokines. The expression of AGER1 can be influenced by the AGE burden in the microenvironment as extensive prolonged AGE exposure downregulates the expression of AGER1 [82]. AGER1 might be a promising target in MS that can decrease AGE load within the CNS and stimulate an antiinflammatory environment. Suppression of NF-KB not only decreases the production of pro-inflammatory cytokines but also leads to an increased phagocytosis capacity of macrophages [158]. Phagocytosis of myelin debris by macrophages is essential to induce remyelination of axons [159]. Therefore, AGER1 activation may be beneficial for remyelination and may prevent neuronal damage. However, to this date, no studies have investigated the contribution of AGER1 to MS pathology.

\section{Aims of the thesis}

Previous research by Sternberg et al. has revealed that AGEs are present in the brain and increased in the plasma of MS patients [78, 79]. Moreover, processes leading to the formation of AGEs, thus glycolysis and lipid peroxidation, are enhanced in MS. These processes can lead to increased levels of MGO-derived AGEs. However, it remains unknown whether AGE levels are increased in the CNS, the primary site of inflammation and demyelination, of MS patients. Moreover, it is unclear whether brain-derived AGEs contribute to the disease pathology of MS.

The aim of this thesis is to elucidate whether AGEs are formed in the CNS during the development of MS in both patients and the experimental animal models of MS. In addition, we aim to investigate the potential effects of AGEs on disease pathology.

First, in chapter 2, we determine the levels of dicarbonyls and AGEs in MS lesions and white matter of non-demented controls. Second, using fluorescent immunohistochemistry, we elucidate which cell types are the major source of AGEs in MS lesions. Finally, we investigate the effects of inflammation on AGE formation in an in vitro model.

Next, we aim to determine the contribution of AGEs to the disease pathology of MS. For this purpose we will use the animal model of MS, EAE. To examine 
whether the changes in AGE levels observed in $M S$ are reflected in $E A E$, we measure the a-dicarbonyl and AGE levels in this animal model (chapter 3). To investigate the potential effect of EAE-induced AGE formation, two different intervention approaches are applied to reduce AGE levels in the plasma, spinal cord and brain of EAE mice.

Besides the formation of AGEs in vivo, dietary AGEs contribute to the in vivo AGE pool. Previous studies have revealed that dietary AGEs are associated with plasma and urinary AGE levels [83]. However, it is still unclear whether dietary AGEs are able to accumulate in tissues and modulate inflammatory responses. In chapter 4, we investigate whether dietary AGEs can accumulate in the CNS. For this purpose two approaches are used. On one hand the mouse diet will be enriched in AGEs by baking and on the other hand MGO will be supplemented in the drinking water. After this dietary intervention, a-dicarbonyl and AGE levels are measured in the plasma and CNS.

To examine whether the accumulated dietary AGEs in the CNS can affect the disease progression of EAE, the baked diet and MGO supplementation in the drinking water are applied during EAE (chapter 5). In addition to disease progression, inflammatory markers are measured to investigate the inflammatory effects of AGEs in neuroinflammation.

Finally, all results are summarized and discussed in chapter 6.

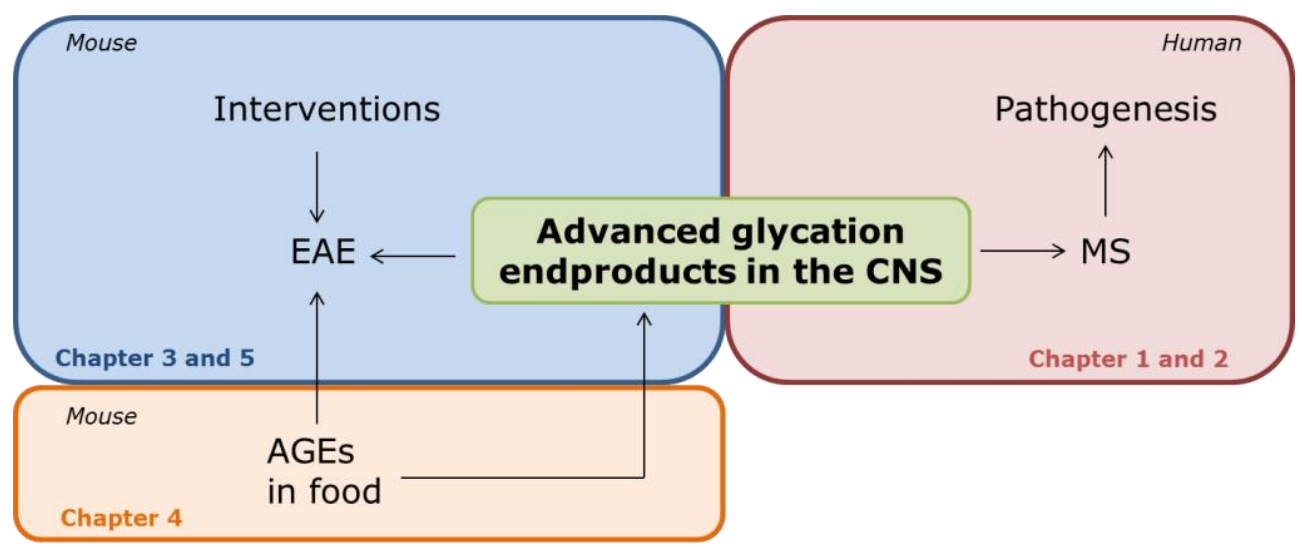

Figure 1.3. Overview of the aims and chapters of this thesis. 


\section{References}

1. Charcot, J., Histologie de la sclerose en plaque. Gazette des Hopitaux, 1868. 41: p. 554-66.

2. Pearce, J.M., Historical descriptions of multiple sclerosis. Eur Neurol, 2005. 54(1): p. 49-53.

3. Kumar, D.R., et al., Jean-Martin Charcot: the father of neurology. Clin Med Res, 2011. 9(1): p. 46-9.

4. Compston, A. and A. Coles, Multiple sclerosis. Lancet, 2008. 372(9648): p. 150217.

5. Bar-Or, A., et al., Molecular pathogenesis of multiple sclerosis. J Neuroimmunol, 1999. 100(1-2): p. 252-9.

6. Hoglund, R.A. and A.A. Maghazachi, Multiple sclerosis and the role of immune cells. World J Exp Med, 2014. 4(3): p. 27-37.

7. Ellwardt, E. and F. Zipp, Molecular mechanisms linking neuroinflammation and neurodegeneration in MS. Experimental neurology, 2014.

8. Scalfari, A., et al., Onset of secondary progressive phase and long-term evolution of multiple sclerosis. J Neurol Neurosurg Psychiatry, 2014. 85(1): p. 67-75.

9. Dorr, J. and F. Paul, The transition from first-line to second-line therapy in multiple sclerosis. Curr Treat Options Neurol, 2015. 17(6): p. 354.

10. Duffy, S.S., J.G. Lees, and G. Moalem-Taylor, The contribution of immune and glial cell types in experimental autoimmune encephalomyelitis and multiple sclerosis. Mult Scler Int, 2014. 2014: p. 285245.

11. McDonald, W.I., et al., Recommended diagnostic criteria for multiple sclerosis: guidelines from the International Panel on the diagnosis of multiple sclerosis. Ann Neurol, 2001. 50(1): p. 121-7.

12. Polman, C.H., et al., Diagnostic criteria for multiple sclerosis: 2010 revisions to the McDonald criteria. Ann Neurol, 2011. 69(2): p. 292-302.

13. Thompson, A.J., et al., Diagnosis of multiple sclerosis: 2017 revisions of the McDonald criteria. Lancet Neurol, 2018. 17(2): p. 162-173.

14. Inglese, M., R.I. Grossman, and M. Filippi, Magnetic resonance imaging monitoring of multiple sclerosis lesion evolution. J Neuroimaging, 2005. 15(4 Suppl): p. 22S-29S.

15. Hafler, D.A., Multiple sclerosis. J Clin Invest, 2004. 113(6): p. 788-94.

16. Awad, A., et al., Analyses of cerebrospinal fluid in the diagnosis and monitoring of multiple sclerosis. J Neuroimmunol, 2010. 219(1-2): p. 1-7.

17. Brownlee, W.J., et al., Diagnosis of multiple sclerosis: progress and challenges. Lancet, 2017. 389(10076): p. 1336-1346.

18. Ortiz, G.G., et al., Role of the blood-brain barrier in multiple sclerosis. Arch Med Res, 2014. 45(8): p. 687-97.

19. International Multiple Sclerosis Genetics, C., et al., Analysis of immune-related loci identifies 48 new susceptibility variants for multiple sclerosis. Nat Genet, 2013. 45(11): p. 1353-60.

20. Hedstrom, A.K., et al., Tobacco smoking, but not Swedish snuff use, increases the risk of multiple sclerosis. Neurology, 2009. 73(9): p. 696-701.

21. Munger, K.L., et al., Vitamin $D$ intake and incidence of multiple sclerosis. Neurology, 2004. 62(1): p. 60-5.

22. Levin, L.I., et al., Primary infection with the Epstein-Barr virus and risk of multiple sclerosis. Ann Neurol, 2010. 67(6): p. 824-30.

23. Simpson, S., Jr., et al., Latitude is significantly associated with the prevalence of multiple sclerosis: a meta-analysis. J Neurol Neurosurg Psychiatry, 2011. 82(10): p. $1132-41$.

24. Bogie, J.F., P. Stinissen, and J.J. Hendriks, Macrophage subsets and microglia in multiple sclerosis. Acta neuropathologica, 2014. 128(2): p. 191-213.

25. Vainchtein, I.D., et al., In acute experimental autoimmune encephalomyelitis, infiltrating macrophages are immune activated, whereas microglia remain immune suppressed. Glia, 2014. 62(10): p. 1724-35. 
26. Ellwardt, E. and F. Zipp, Molecular mechanisms linking neuroinflammation and neurodegeneration in MS. Exp Neurol, 2014. 262 Pt A: p. 8-17.

27. Weber, M.S. and B. Hemmer, Cooperation of $B$ cells and $T$ cells in the pathogenesis of multiple sclerosis. Results Probl Cell Differ, 2010. 51: p. 115-26.

28. Lehmann-Horn, K., H.C. Kronsbein, and M.S. Weber, Targeting $B$ cells in the treatment of multiple sclerosis: recent advances and remaining challenges. Ther Adv Neurol Disord, 2013. 6(3): p. 161-73.

29. Nair, A., T.J. Frederick, and S.D. Miller, Astrocytes in multiple sclerosis: a product of their environment. Cell Mol Life Sci, 2008. 65(17): p. 2702-20.

30. Hemmer, B., M. Kerschensteiner, and T. Korn, Role of the innate and adaptive immune responses in the course of multiple sclerosis. Lancet Neurol, 2015. 14(4): p. 406-19.

31. Mahad, D.H., B.D. Trapp, and H. Lassmann, Pathological mechanisms in progressive multiple sclerosis. Lancet Neurol, 2015. 14(2): p. 183-93.

32. Bermel, R.A. and R.A. Rudick, Interferon-beta treatment for multiple sclerosis. Neurotherapeutics, 2007. 4(4): p. 633-46.

33. Rudick, R.A. and S.E. Goelz, Beta-interferon for multiple sclerosis. Exp Cell Res, 2011. 317(9): p. 1301-11.

34. Farina, C., et al., Glatiramer acetate in multiple sclerosis: update on potential mechanisms of action. Lancet Neurol, 2005. 4(9): p. 567-75.

35. McKeage, K., Glatiramer Acetate $40 \mathrm{mg} / \mathrm{mL}$ in Relapsing-Remitting Multiple Sclerosis: A Review. CNS Drugs, 2015. 29(5): p. 425-32.

36. Bar-Or, A., et al., Teriflunomide and its mechanism of action in multiple sclerosis. Drugs, 2014. 74(6): p. 659-74.

37. Miller, A.E., Oral teriflunomide in the treatment of relapsing forms of multiple sclerosis: clinical evidence and long-term experience. Ther Adv Neurol Disord, 2017. 10(12): p. 381-396.

38. Mills, E.A., et al., Emerging Understanding of the Mechanism of Action for Dimethyl Fumarate in the Treatment of Multiple Sclerosis. Front Neurol, 2018. 9: p. 5.

39. Evan, J.R., et al., Alemtuzumab for the treatment of multiple sclerosis. Expert Opin Biol Ther, 2018. 18(3): p. 323-334.

40. Gajofatto, A. and M.D. Benedetti, Treatment strategies for multiple sclerosis: When to start, when to change, when to stop? World J Clin Cases, 2015. 3(7): p. 545-55.

41. Jeffery, D.R., et al., Fingolimod for the treatment of relapsing multiple sclerosis. Expert Rev Neurother, 2011. 11(2): p. 165-83.

42. Wang, L., et al., Efficacy of alemtuzumab and natalizumab in the treatment of different stages of multiple sclerosis patients. Medicine (Baltimore), 2018. 97(8): p. e9908.

43. Wingerchuk, D.M. and B.G. Weinshenker, Disease modifying therapies for relapsing multiple sclerosis. BMJ, 2016. 354: p. i3518.

44. Hohlfeld, R. and E. Meinl, Ocrelizumab in multiple sclerosis: markers and mechanisms. Lancet Neurol, 2017. 16(4): p. 259-261.

45. Salzer, J., et al., Rituximab in multiple sclerosis: $A$ retrospective observational study on safety and efficacy. Neurology, 2016. 87(20): p. 2074-2081.

46. Stahnke, A.M. and K.M. Holt, Ocrelizumab: A New B-cell Therapy for Relapsing Remitting and Primary Progressive Multiple Sclerosis. Ann Pharmacother, 2018. 52(5): p. 473-483.

47. Bloomgren, G., et al., Risk of natalizumab-associated progressive multifocal leukoencephalopathy. N Engl J Med, 2012. 366(20): p. 1870-80.

48. Martinelli Boneschi, F., et al., Mitoxantrone for multiple sclerosis. Cochrane Database Syst Rev, 2013(5): p. CD002127.

49. Ellis, R., S. Brown, and M. Boggild, Therapy-related acute leukaemia with mitoxantrone: four years on, what is the risk and can it be limited? Mult Scler, 2015. 21(5): p. 642-5.

50. Marriott, J.J., et al., Evidence Report: The efficacy and safety of mitoxantrone (Novantrone) in the treatment of multiple sclerosis: Report of the Therapeutics 
and Technology Assessment Subcommittee of the American Academy of Neurology. Neurology, 2010. 74(18): p. 1463-70.

51. Curro, D. and G. Mancardi, Autologous hematopoietic stem cell transplantation in multiple sclerosis: 20 years of experience. Neurol Sci, 2016. 37(6): p. 857-65.

52. Muraro, P.A., et al., Autologous haematopoietic stem cell transplantation for treatment of multiple sclerosis. Nat Rev Neurol, 2017. 13(7): p. 391-405.

53. Fassas, A., et al., Peripheral blood stem cell transplantation in the treatment of progressive multiple sclerosis: first results of a pilot study. Bone Marrow Transplant, 1997. 20(8): p. 631-8.

54. Mancardi, G.L., et al., Autologous hematopoietic stem cell transplantation in multiple sclerosis: a phase II trial. Neurology, 2015. 84(10): p. 981-8.

55. Nash, R.A., et al., High-dose immunosuppressive therapy and autologous HCT for relapsing-remitting MS. Neurology, 2017. 88(9): p. 842-852.

56. Procaccini, C., et al., Animal models of Multiple Sclerosis. Eur J Pharmacol, 2015. 759: p. 182-91.

57. Tompkins, S.M., et al., De novo central nervous system processing of myelin antigen is required for the initiation of experimental autoimmune encephalomyelitis. J Immunol, 2002. 168(8): p. 4173-83.

58. Tuohy, V.K., et al., Identification of an encephalitogenic determinant of myelin proteolipid protein for SJL mice. J Immunol, 1989. 142(5): p. 1523-7.

59. Stromnes, I.M. and J.M. Goverman, Passive induction of experimental allergic encephalomyelitis. Nat Protoc, 2006. 1(4): p. 1952-60.

60. Batoulis, H., et al., Experimental autoimmune encephalomyelitis--achievements and prospective advances. APMIS, 2011. 119(12): p. 819-30.

61. Rangachari, M. and V.K. Kuchroo, Using EAE to better understand principles of immune function and autoimmune pathology. J Autoimmun, 2013. 45: p. 31-9.

62. Baxter, A.G., The origin and application of experimental autoimmune encephalomyelitis. Nat Rev Immunol, 2007. 7(11): p. 904-12.

63. Baker, D. and S. Amor, Experimental autoimmune encephalomyelitis is a good model of multiple sclerosis if used wisely. Mult Scler Relat Disord, 2014. 3(5): p. 555-64.

64. van Oosten, B.W., et al., Increased MRI activity and immune activation in two multiple sclerosis patients treated with the monoclonal anti-tumor necrosis factor antibody cA2. Neurology, 1996. 47(6): p. 1531-4.

65. Wiendl, H. and R. Hohlfeld, Therapeutic approaches in multiple sclerosis: lessons from failed and interrupted treatment trials. BioDrugs, 2002. 16(3): p. 183-200.

66. Hunig, T., Manipulation of regulatory T-cell number and function with CD28specific monoclonal antibodies. Adv Immunol, 2007. 95: p. 111-48.

67. Blakemore, W.F. and R.J. Franklin, Remyelination in experimental models of toxin-induced demyelination. Curr Top Microbiol Immunol, 2008. 318: p. 193212.

68. Jeffery, N.D. and W.F. Blakemore, Remyelination of mouse spinal cord axons demyelinated by local injection of lysolecithin. J Neurocytol, 1995. 24(10): p. 775-81.

69. Stitt, A.W., et al., Advanced glycation end products (AGES) co-localize with AGE receptors in the retinal vasculature of diabetic and of AGE-infused rats. Am J Pathol, 1997. 150(2): p. 523-31.

70. van Eupen, M.G., et al., The methylglyoxal-derived AGE tetrahydropyrimidine is increased in plasma of individuals with type 1 diabetes mellitus and in atherosclerotic lesions and is associated with sVCAM-1. Diabetologia, 2013. 56(8): p. 1845-55.

71. Hanssen, N.M., et al., Higher levels of advanced glycation endproducts in human carotid atherosclerotic plaques are associated with a rupture-prone phenotype. Eur Heart J, 2014. 35(17): p. 1137-46.

72. Gaens, K.H.J., et al., N-epsilon-(Carboxymethyl) lysine- Receptor for Advanced Glycation End Product Axis Is a Key Modulator of Obesity-Induced Dysregulation of Adipokine Expression and Insulin Resistance. Arteriosclerosis Thrombosis and Vascular Biology, 2014. 34(6): p. 1199-1208. 
73. Gaens, K.H., et al., Endogenous formation of Nepsilon-(carboxymethyl)lysine is increased in fatty livers and induces inflammatory markers in an in vitro model of hepatic steatosis. J Hepatol, 2012. 56(3): p. 647-55.

74. Ahmed, N., et al., Protein glycation, oxidation and nitration adduct residues and free adducts of cerebrospinal fluid in Alzheimer's disease and link to cognitive impairment. J Neurochem, 2005. 92(2): p. 255-63.

75. Dalfo, E., et al., Evidence of oxidative stress in the neocortex in incidental Lewy body disease. J Neuropathol Exp Neurol, 2005. 64(9): p. 816-30.

76. Ledesma, M.D., P. Bonay, and J. Avila, Tau protein from Alzheimer's disease patients is glycated at its tubulin-binding domain. J Neurochem, 1995. 65(4): p. 1658-64.

77. Vitek, M.P., et al., Advanced glycation end products contribute to amyloidosis in Alzheimer disease. Proc Natl Acad Sci U S A, 1994. 91(11): p. 4766-70.

78. Sternberg, Z., et al., Diagnostic potential of plasma carboxymethyllysine and carboxyethyllysine in multiple sclerosis. Journal of neuroinflammation, 2010. 7: p. 72.

79. Sternberg, Z., et al., AGE-RAGE in multiple sclerosis brain. Immunol Invest, 2011. 40(2): p. 197-205.

80. Gaens, K.H., C.D. Stehouwer, and C.G. Schalkwijk, Advanced glycation endproducts and its receptor for advanced glycation endproducts in obesity. Current opinion in lipidology, 2013. 24(1): p. 4-11.

81. Singh, R., et al., Advanced glycation end-products: a review. Diabetologia, 2001. 44(2): p. 129-46.

82. Poulsen, M.W., et al., Advanced glycation endproducts in food and their effects on health. Food Chem Toxicol, 2013. 60: p. 10-37.

83. Scheijen J.L.J.M, H.N.M.J., van Greevenbroek M.M., Van der Kallen C.J., Feskens E.J.M., Stehouwer C.D.A., Schalkwijk C.G. , Dietary intake of advanced glycation endproducts is associated with higher levels of advanced glycation endproducts in plasma and urine: The CODAM study. Clinical Nutrition 2017.

84. Uribarri, J., et al., Circulating glycotoxins and dietary advanced glycation endproducts: two links to inflammatory response, oxidative stress, and aging. J Gerontol A Biol Sci Med Sci, 2007. 62(4): p. 427-33.

85. Vlassara, H., et al., Protection against loss of innate defenses in adulthood by low advanced glycation end products (AGE) intake: role of the antiinflammatory AGE receptor-1. J Clin Endocrinol Metab, 2009. 94(11): p. 4483-91.

86. Allaman, I., M. Belanger, and P.J. Magistretti, Methylglyoxal, the dark side of glycolysis. Front Neurosci, 2015. 9: p. 23.

87. Maessen, D.E., C.D. Stehouwer, and C.G. Schalkwijk, The role of methylglyoxal and the glyoxalase system in diabetes and other age-related diseases. Clin Sci (Lond), 2015. 128(12): p. 839-61.

88. Lange, J.N., et al., Glyoxal formation and its role in endogenous oxalate synthesis. Adv Urol, 2012. 2012: p. 819202.

89. Pamplona, R., Advanced lipoxidation end-products. Chem Biol Interact, 2011. 192(1-2): p. 14-20.

90. Vistoli, G., et al., Advanced glycoxidation and lipoxidation end products (AGEs and ALES): an overview of their mechanisms of formation. Free Radic Res, 2013. 47 Suppl 1: p. 3-27.

91. Matafome, P., C. Sena, and R. Seica, Methylglyoxal, obesity, and diabetes. Endocrine, 2013. 43(3): p. 472-84.

92. Di Loreto, S., et al., Methylglyoxal induces oxidative stress-dependent cell injury and up-regulation of interleukin-1beta and nerve growth factor in cultured hippocampal neuronal cells. Brain Res, 2004. 1006(2): p. 157-67.

93. Figarola, J.L., et al., LR-90 prevents methylglyoxal-induced oxidative stress and apoptosis in human endothelial cells. Apoptosis, 2014. 19(5): p. 776-88.

94. Brownlee, M., Biochemistry and molecular cell biology of diabetic complications. Nature, 2001. 414(6865): p. 813-20. 
95. Gaens, K.H., C.D. Stehouwer, and C.G. Schalkwijk, Advanced glycation endproducts and its receptor for advanced glycation endproducts in obesity. Curr Opin Lipidol, 2013. 24(1): p. 4-11.

96. Ott, C., et al., Role of advanced glycation end products in cellular signaling. Redox Biol, 2014. 2: p. 411-29.

97. Yan, S.F., R. Ramasamy, and A.M. Schmidt, The RAGE axis: a fundamental mechanism signaling danger to the vulnerable vasculature. Circ Res, 2010. 106(5): p. 842-53.

98. Dukic-Stefanovic, S., et al., Signal transduction pathways in mouse microglia $\mathrm{N}$ 11 cells activated by advanced glycation endproducts (AGEs). J Neurochem, 2003. 87(1): p. 44-55.

99. Wang, A.L., et al., Sinomenine inhibits activation of rat retinal microglia induced by advanced glycation end products. Int Immunopharmacol, 2007. 7(12): p. 1552-8.

100. Wang, L., et al., DHA inhibited AGEs-induced retinal microglia activation via suppression of the PPARgamma/NFkappaB pathway and reduction of signal transducers in the AGES/RAGE axis recruitment into lipid rafts. Neurochem Res, 2015. 40(4): p. 713-22.

101. Shaikh, S.B., et al., AGEs-RAGE mediated up-regulation of connexin43 in activated human microglial CHME-5 cells. Neurochem Int, 2012. 60(6): p. 64051.

102. Wang, Z., et al., Activation of astrocytes by advanced glycation end products: cytokines induction and nitric oxide release. Acta Pharmacol Sin, 2002. 23(11): p. 974-80.

103. Wang, J., et al., High glucose-induced expression of inflammatory cytokines and reactive oxygen species in cultured astrocytes. Neuroscience, 2012. 202: p. 5868.

104. Begley, D.J. and M.W. Brightman, Structural and functional aspects of the bloodbrain barrier. Prog Drug Res, 2003. 61: p. 39-78.

105. Hussain, M., et al., Novel insights in the dysfunction of human blood-brain barrier after glycation. Mech Ageing Dev, 2016. 155: p. 48-54.

106. Shimizu, F., et al., Advanced glycation end-products disrupt the blood-brain barrier by stimulating the release of transforming growth factor-beta by pericytes and vascular endothelial growth factor and matrix metalloproteinase-2 by endothelial cells in vitro. Neurobiol Aging, 2013. 34(7): p. 1902-12.

107. Keaney, J. and M. Campbell, The dynamic blood-brain barrier. FEBS J, 2015. 282(21): p. 4067-79.

108. Abbott, N.J., L. Ronnback, and E. Hansson, Astrocyte-endothelial interactions at the blood-brain barrier. Nat Rev Neurosci, 2006. 7(1): p. 41-53.

109. Miyajima, H., et al., Glyceraldehyde-derived advanced glycation end-products preferentially induce VEGF expression and reduce GDNF expression in human astrocytes. Biochem Biophys Res Commun, 2005. 330(2): p. 361-6.

110. Carvalho, A.N., et al., Glutathione in multiple sclerosis: more than just an antioxidant? Mult Scler, 2014. 20(11): p. 1425-31.

111. Calabrese, V., et al., Nitric oxide synthase is present in the cerebrospinal fluid of patients with active multiple sclerosis and is associated with increases in cerebrospinal fluid protein nitrotyrosine and S-nitrosothiols and with changes in glutathione levels. J Neurosci Res, 2002. 70(4): p. 580-7.

112. Choi, I.Y., et al., Lower levels of glutathione in the brains of secondary progressive multiple sclerosis patients measured by $1 \mathrm{H}$ magnetic resonance chemical shift imaging at 3 T. Mult Scler, 2011. 17(3): p. 289-96.

113. Srinivasan, R., et al., MR spectroscopic imaging of glutathione in the white and gray matter at $7 T$ with an application to multiple sclerosis. Magn Reson Imaging, 2010. 28(2): p. 163-70.

114. Junaid, M.A., et al., Proteomic studies identified a single nucleotide polymorphism in glyoxalase I as autism susceptibility factor. Am J Med Genet A, 2004. 131(1): p. 11-7. 
115. Sidoti, A., et al., Glyoxalase I A111E, paraoxonase 1 Q192R and L55M polymorphisms: susceptibility factors of multiple sclerosis? Mult Scler, 2007. 13(4): p. 446-53.

116. Kelly, B. and L.A. O'Neill, Metabolic reprogramming in macrophages and dendritic cells in innate immunity. Cell Res, 2015. 25(7): p. 771-84.

117. Orihuela, R., C.A. McPherson, and G.J. Harry, Microglial M1/M2 polarization and metabolic states. $\mathrm{Br}$ J Pharmacol, 2015.

118. Bittner, C.X., et al., High resolution measurement of the glycolytic rate. Front Neuroenergetics, 2010. 2.

119. Herrero-Mendez, A., et al., The bioenergetic and antioxidant status of neurons is controlled by continuous degradation of a key glycolytic enzyme by APC/C-Cdh1. Nat Cell Biol, 2009. 11(6): p. 747-52.

120. Itoh, Y., et al., Dichloroacetate effects on glucose and lactate oxidation by neurons and astroglia in vitro and on glucose utilization by brain in vivo. Proc Natl Acad Sci U S A, 2003. 100(8): p. 4879-84.

121. Karnovsky, M.L., Metabolic basis of phagocytic activity. Physiol Rev, 1962. 42: p. 143-68.

122. Bogie, J.F., et al., Myelin-derived lipids modulate macrophage activity by liver $X$ receptor activation. PLoS One, 2012. 7(9): p. e44998.

123. Belanger, M., I. Allaman, and P.J. Magistretti, Brain energy metabolism: focus on astrocyte-neuron metabolic cooperation. Cell Metab, 2011. 14(6): p. 724-38.

124. Nijland, P.G., et al., Cellular distribution of glucose and monocarboxylate transporters in human brain white matter and multiple sclerosis lesions. Glia, 2014. 62(7): p. 1125-41.

125. Jurcovicova, J., Glucose transport in brain - effect of inflammation. Endocr Regul, 2014. 48(1): p. 35-48.

126. Trapp, B.D. and P.K. Stys, Virtual hypoxia and chronic necrosis of demyelinated axons in multiple sclerosis. Lancet Neurol, 2009. 8(3): p. 280-91.

127. Schiepers, C., et al., Positron emission tomography, magnetic resonance imaging and proton NMR spectroscopy of white matter in multiple sclerosis. Mult Scler, 1997. 3(1): p. 8-17.

128. Schocke, M.F., et al., Serial contrast-enhanced magnetic resonance imaging and spectroscopic imaging of acute multiple sclerosis lesions under high-dose methylprednisolone therapy. Neuroimage, 2003. 20(2): p. 1253-63.

129. Morland, C., et al., Evidence for a higher glycolytic than oxidative metabolic activity in white matter of rat brain. Neurochem Int, 2007. 50(5): p. 703-9.

130. Funfschilling, U., et al., Glycolytic oligodendrocytes maintain myelin and longterm axonal integrity. Nature, 2012. 485(7399): p. 517-21.

131. van Horssen, J., et al., Radical changes in multiple sclerosis pathogenesis. Biochim Biophys Acta, 2011. 1812(2): p. 141-50.

132. Ljubisavljevic, S., Oxidative Stress and Neurobiology of Demyelination. Mol Neurobiol, 2014.

133. Mattsson, N., et al., Elevated cerebrospinal fluid F2-isoprostane levels indicating oxidative stress in healthy siblings of multiple sclerosis patients. Neurosci Lett, 2007. 414(3): p. 233-6.

134. Colton, C.A. and D.L. Gilbert, Microglia, an in vivo source of reactive oxygen species in the brain. Adv Neurol, 1993. 59: p. 321-6.

135. Guan, J.Z., et al., Patients with multiple sclerosis show increased oxidative stress markers and somatic telomere length shortening. Mol Cell Biochem, 2015. 400(12): p. 183-7.

136. van Horssen, J., et al., Severe oxidative damage in multiple sclerosis lesions coincides with enhanced antioxidant enzyme expression. Free Radic Biol Med, 2008. 45(12): p. 1729-37.

137. Wang, P., et al., Oxidative stress induced by lipid peroxidation is related with inflammation of demyelination and neurodegeneration in multiple sclerosis. Eur Neurol, 2014. 72(3-4): p. 249-54. 
138. Andersson, A., et al., Pivotal advance: HMGB1 expression in active lesions of human and experimental multiple sclerosis. J Leukoc Biol, 2008. 84(5): p. 124855.

139. Yan, S.S., et al., Suppression of experimental autoimmune encephalomyelitis by selective blockade of encephalitogenic T-cell infiltration of the central nervous system. Nat Med, 2003. 9(3): p. 287-93.

140. Ding, Q. and J.N. Keller, Evaluation of rage isoforms, ligands, and signaling in the brain. Biochim Biophys Acta, 2005. 1746(1): p. 18-27.

141. Liliensiek, B., et al., Receptor for advanced glycation end products (RAGE) regulates sepsis but not the adaptive immune response. J Clin Invest, 2004. 113(11): p. 1641-50.

142. Sternberg, Z., et al., Reduced expression of membrane-bound (m)RAGE is a biomarker of multiple sclerosis disease progression. Immunobiology, 2016. 221(2): p. 193-8.

143. Sternberg, Z., et al., Soluble receptor for advanced glycation end products in multiple sclerosis: a potential marker of disease severity. Multiple sclerosis, 2008. 14(6): p. 759-63.

144. Hofmann, M.A., et al., RAGE and arthritis: the G82S polymorphism amplifies the inflammatory response. Genes Immun, 2002. 3(3): p. 123-35.

145. Hudson, B.I., et al., Effects of novel polymorphisms in the RAGE gene on transcriptional regulation and their association with diabetic retinopathy. Diabetes, 2001. 50(6): p. 1505-11.

146. Tiszlavicz, Z., et al., RAGE gene polymorphisms in patients with multiple sclerosis. Journal of molecular neuroscience : MN, 2009. 39(3): p. 360-5.

147. Li, K., et al., A functional p.82G $>S$ polymorphism in the RAGE gene is associated with multiple sclerosis in the Chinese population. Multiple sclerosis, 2011. 17(8): p. 914-21.

148. Sternberg, Z., et al., High-mobility group box 1 in multiple sclerosis. Immunol Res, 2016. 64(2): p. 385-91.

149. Malhotra, S., et al., Role of high mobility group box protein 1 (HMGB1) in peripheral blood from patients with multiple sclerosis. J Neuroinflammation, 2015. 12: p. 48.

150. Uzawa, A., et al., Anti-high mobility group box 1 monoclonal antibody ameliorates experimental autoimmune encephalomyelitis. Clin Exp Immunol, 2013. 172(1): p. 37-43.

151. Robinson, A.P., et al., High-mobility group box 1 protein (HMGB1) neutralization ameliorates experimental autoimmune encephalomyelitis. J Autoimmun, 2013. 43: p. 32-43.

152. Sun, Y., et al., HMGB1 expression patterns during the progression of experimental autoimmune encephalomyelitis. J Neuroimmunol, 2015. 280: p. 2935.

153. Barateiro, A., et al., $\mathrm{S} 100 \mathrm{~B}$ as a Potential Biomarker and Therapeutic Target in Multiple Sclerosis. Molecular Neurobiology, 2016. 53(6): p. 3976-3991.

154. Bartosik-Psujek, H., et al., Total tau and S100b proteins in different types of multiple sclerosis and during immunosuppressive treatment with mitoxantrone. Acta Neurologica Scandinavica, 2011. 123(4): p. 252-256.

155. Rejdak, K., et al., Astrocytic activation in relation to inflammatory markers during clinical exacerbation of relapsing-remitting multiple sclerosis. Journal of Neural Transmission, 2007. 114(8): p. 1011-1015.

156. Lim, E.T., et al., Serum S100B in primary progressive multiple sclerosis patients treated with interferon-beta-1a. J Negat Results Biomed, 2004. 3: p. 4.

157. Cai, W., et al., Oral advanced glycation endproducts (AGES) promote insulin resistance and diabetes by depleting the antioxidant defenses AGE receptor-1 and sirtuin 1. Proc Natl Acad Sci U S A, 2012. 109(39): p. 15888-93.

158. Jiang, Z., J.X. Jiang, and G.X. Zhang, Macrophages: a double-edged sword in experimental autoimmune encephalomyelitis. Immunol Lett, 2014. 160(1): p. 17-22. 
159. Kotter, M.R., et al., Macrophage-depletion induced impairment of experimental CNS remyelination is associated with a reduced oligodendrocyte progenitor cell response and altered growth factor expression. Neurobiol Dis, 2005. 18(1): p. 166-75. 
This chapter is embargoed at request

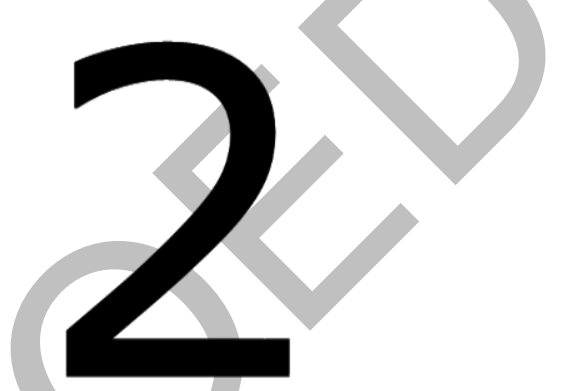

\section{Methylglyoxal-derived advanced glycation endproducts are produced by activated astrocytes and accumulate in multiple sclerosis lesions}

Suzan Wetzels, Tim Vanmierlo, Jean Scheijen, Jack van Horssen, Sandra Amor, Veerle Somers, Casper Schalkwijk, Jerome Hendriks*, Kristiaan Wouters*

* These authors contributed equally to this work Submitted to Frontiers in Immunology 


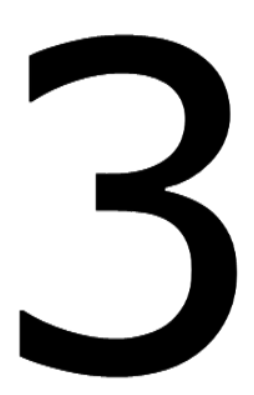

\section{Advanced glycation endproducts are increased in the animal model of multiple sclerosis but cannot be reduced by pyridoxamine treatment or glyoxalase 1}

Suzan Wetzels, Kristiaan Wouters, Toshio Miyata, Jean L. J. M. Scheijen, Jerome J.A. Hendriks, Casper G. Schalkwijk*, Tim Vanmierlo*

* These authors contributed equally to this work Int. J. Mol. Sci. 2018, 19(5) 


\section{Abstract}

Multiple sclerosis (MS) is a demyelinating autoimmune disease of the central nervous system (CNS). The immune response in MS patients leads to the infiltration of immune cells in the CNS and their subsequent activation. Immune cell activation induces a switch towards glycolysis. During glycolysis, the dicarbonyl product methylglyoxal (MGO) is produced. MGO is a glycating agent that can rapidly form advanced glycation endproducts (AGEs). In turn, AGEs are able to induce inflammatory responses. The glyoxalase system is the endogenous defense system of the body to reduce the burden of MGO thereby reducing AGE formation. This system consists of glyoxalase-1 and glyoxalase-2 which are able to detoxify MGO to D-lactate. We investigated whether AGE levels are induced in experimental autoimmune encephalitis (EAE), an inflammatory animal model of MS. Twenty seven days post EAE induction, MGO and AGE ( $N^{\varepsilon}$-(carboxymethyl)lysine (CML), $N^{\varepsilon}$-(carboxyethyl)lysine (CEL), 5hydro-5-methylimidazolone (MG-H1) levels were significantly increased in the spinal cord of mice subjected to EAE. Yet, pyridoxamine treatment and glyoxalase-1 overexpression were unable to counteract AGE production during EAE and did not influence the clinical course of EAE. In conclusion, AGEs levels increase during $E A E$ in the spinal cord, but AGE-modifying treatments do not inhibit EAE-induced AGE production and do not affect disease progression. 


\section{Introduction}

Multiple sclerosis (MS) is a demyelinating autoimmune disease of the central nervous system (CNS) [1]. Worldwide, 2.5 million people are diagnosed with MS; mainly young adults as the disease manifests between 20 and 40 years of age. These patients have a variety of symptoms including muscle weakness, paresthesias, ataxia, and visual disturbances, depending on the brain regions attacked by the immune system [2]. Most MS patients, $85 \%$, have the typical relapsing-remitting (RR) MS disease course which results in periods of inflammatory events leading to relapses with clinical disability followed by episodes of full recovery [2]. However, as the disease progresses, over half of the RR MS patients enter a more progressive disease course called secondary progressive (SP) MS, which is characterized by progressive disability without episodes of full recovery [1].

The exact etiology of MS remains unknown. However, there is consensus that MS is triggered by environmental factors in genetically susceptible hosts. This leads to an immune response targeted at the myelin sheaths surrounding the axons. Whether this immune response is initiated inside or outside of the CNS is, to date, still unclear. Nevertheless, it is certain that both the innate immune system, comprised of the CNS-resident microglia and the monocyte-infiltrated macrophages, and adaptive immune system, consisting of cell such as the Tlymphocytes and B-lymphocytes play a key role [3]. Autoreactive T-lymphocytes are recruited to the CNS by the secretion of chemokines by infiltrated macrophages and CNS-resident microglia. Once in the CNS, autoreactive Tlymphocytes are reactivated by microglia and infiltrated macrophages thereby promoting neuroinflammation and neurodegeneration [4]. To investigate the development of MS and validate novel therapeutics, animal models of MS have been developed. The experimental autoimmune encephalomyelitis (EAE) is the most widely accepted animal model of MS [5]. Immunization of mice with selfantigens (e.g., myelin oligodendrocyte glycoprotein (MOG)) induces an autoimmune response of $\mathrm{CD}^{+}$and $\mathrm{CD}^{+}$T-lymphocytes, B-lymphocytes and monocytes [6], mimicking the immune response in MS patients. Subsequently, the autoimmune response leads to neuroinflammation and demyelination, primarily in the spinal cord [7].

The activation of CNS-resident microglia and infiltrated macrophages can induce a switch in metabolism in these cells promoting glycolysis over oxidative phosphorylation [8, 9]. Increased glycolysis can lead to the formation of the byproduct methylglyoxal (MGO) and glyoxal (GO). MGO and GO are potent glycating agents that, reacting with free amino acids, lead to the formation of advanced glycation endproducts (AGEs) [10]. Interaction of MGO with lysine and arginine leads to the formation of $\mathrm{N}^{\varepsilon}$-(1-carboxyethyl)lysine (CEL) and $\mathrm{N}^{\delta}-(5-$ hydro-5-methyl-4-imidazolon-2-yl)-ornithine (MG-H1) respectively, whereas interaction with $\mathrm{GO}$ with lysine leads to the formation of $\mathrm{N}^{\varepsilon_{-}}$ (carboxymethyl)lysine (CML) [11]. However, whether the pro-inflammatory 
environment of the CNS in MS leads to the increased formation of AGEs remains to be elucidated. AGEs can contribute to inflammation by binding to their receptor for advanced glycation endproducts (RAGE), resulting in the activation of downstream pathways including nuclear factor-KB (NF-KB), which leads to the production of pro-inflammatory cytokines and oxidative stress [12]. AGEs are known to be increased in diseases in which inflammation is a major component such as atherosclerosis [13, 14], obesity [15], non-alcoholic steatohepatitis [16] and diabetes [17]. Moreover, it has been shown that AGEs are present in neurodegenerative diseases such as Alzheimer's disease and Parkinson's disease $[18,19]$. Furthermore, studies have also confirmed the presence of AGEs in the brain and plasma of MS patients $[20,21]$. This could indicate that during MS, the formation of AGEs may contribute to neuroinflammation, making them a possible therapeutic target.

To reduce the burden of MGO and AGEs, the body has defense mechanisms such as the glyoxalase system. This system comprises of two enzymes: glyoxalase-1 (Glo-1) and glyoxalase-2 (Glo-2) which are able to detoxify MGO into D-Lactate using glutathione (GSH) as a cofactor [22]. In addition to our body's defence mechanism, there are also pharmacological agents that are able to lower AGE levels such as pyridoxamine. Pyridoxamine is one of the natural vitamin B6 analogues that scavenges MGO thereby preventing AGE formation [23]. Therefore, both pyridoxamine and Glo-1 stimulating agents are potential therapeutic targets that could be used to reduce AGEs.

In the current study, we investigated whether AGE levels are induced in the EAE animal model of MS. Moreover, with pyridoxamine treatment and by the Glo-1 overexpression animal model we aimed to reduce AGE levels in the plasma and CNS of mice subjected to EAE, thereby decreasing the disease progression.

\section{Material \& methods}

\section{Animal experiments}

First, sixteen 9-week old female C57Bl/6JOlaHsd mice were purchased (Envigo, Venray, the Netherlands) and randomly distributed over two groups $(n=8)$. Mice were left to acclimatize for 9 days in the animal facility. Experimental autoimmune encephalomyelitis (EAE) was induced according to manufacturer's instructions (Hooke Laboratories, St. Lawrence, MA, USA) using $200 \mu \mathrm{g}$ myelin oligodendrocyte glycoprotein $\left(M_{30} \mathrm{G}_{35}\right.$ ) emulsified in $200 \mu \mathrm{l}$ complete freund's adjuvant (CFA) containing $5 \mathrm{mg} / \mathrm{ml}$ Mycobacterium tuberculosis and 2 injections of $100 \mathrm{ng}$ pertussis toxin. Mice were weighed and scored for EAE disease progression using a scale for neurological symptoms: $0=$ no neurological symptoms, $0.5=$ limp tail tip, $1=$ complete limp tail, $1.5=$ limp tail and hind leg inhibition, 2 = limp tail and weakness of both hind limbs, $2.5=$ limp tail and dragging of hind limbs, $3=$ limp tail and complete paralysis of hind limbs, $3.5=$ 
limp tail, complete paralysis of hind limbs and mouse is unable to right itself when placed on the side, $4=\operatorname{limb}$ tail, complete hind limb and partial front limb paralysis, mouse remains alert, $4.5=\operatorname{limb}$ tail, complete hind limb and partial front limb paralysis, mouse is not alert, $5=$ moribund or death due to EAE. After 27 days of EAE, mice were euthanized with Nembutal (Val d'Hony-Verdifarm, Beringen, Belgium) and plasma, spinal cord and brain was isolated for further analysis.

Second, twenty-two 10-week old female C57BI/6JOlaHsd mice were purchased (Envigo, Venray, the Netherlands) and randomly distributed over two cages ( $n=$ 11). Mice were able to acclimatize for 7 days in the animal facility before the start of the intervention. To reduce AGE formation, the vitamin B6 analogue pyridoxamine (PM) $(10 \mathrm{~g} / \mathrm{L})$ was administered by $0.5 \mathrm{ml}$ oral gavage twice daily. PM was kindly provided by Prof. Miyata. To prevent any cage-effects, mice were randomly assigned to the intervention or control group in both cages. Administration of vehicle or intervention was done blinded. After two days of intervention, EAE was induced as described above. Mice continued with the twice daily intervention of PM or vehicle during EAE and were weighed and scored as described above. Mice received the last dose of PM via oral gavage 22 days after induction of EAE. Two hours after oral gavage, mice were euthanized with Nembutal (Val d'Hony-Verdifarm, Beringen, Belgium) and plasma and spinal cord was isolated for further analysis.

Finally, heterozygous $\mathrm{C} 57 \mathrm{BI} / 6 \mathrm{~J}$ mice with a universal overexpression of the human Glo-1 enzyme were kindly provided by Prof. Miyata [24]. Female heterozygous Glo-1 overexpressing mice $(n=5)$ and wild type littermates $(n=$ 4) were used. At 11-13 weeks of age, EAE was induced as described above. Mice were weighed and scored daily. After 25 days of EAE, mice were euthanized with Nembutal (Val d'Hony-Verdifarm, Beringen, Belgium) and plasma, spinal cord and brain was isolated for further analysis.

All experiments were approved by the local ethical committee for animal experiments of Hasselt University and performed according to the institutional guidelines (matrix 201557, 201557A1, 201636).

\section{a-Dicarbonyl and AGE measurements}

Spinal cord and brain were used to make $5 \%$ protein homogenates in $0,1 \mathrm{M}$ sodium phosphate buffer $(\mathrm{pH} 6,8)$ supplemented with protease inhibitor (Roche, Basel, Switzerland) and 0,02\% Triton-x.

The dicarbonyls methylglyoxal (MGO), glyoxal (GO) and 3-deoxyglucosone (3DG), and the free and protein-bound form of AGEs $\mathrm{N}^{\varepsilon}$-(carboxymethyl)lysine (CML), $\mathrm{N}^{\varepsilon}$-(1-carboxyethyl)lysine (CEL) and $\mathrm{N}^{\delta}$-(5-hydro-5-methyl-4-imidazolon2-yl)-ornithine (MG-H1) were analysed in the plasma, spinal cord and brain of mice using ultra-performance liquid chromatography tandem mass spectrometry (UPLC MSMS) as described previously [13, 25]. 


\section{Glyoxalase-1 activity assay}

Glyoxalase-1 (Glo-1) activity was measured in protein homogenates of the spinal cord and brain as previously described by McLellan et al [26]. In short, Glo-1 activity was determined by measuring the formation of S-DLactoylglutathione from MGO at an absorbance of $240 \mathrm{~nm}$ during $30 \mathrm{~min}$ using a spectrophotometry analysis.

\section{Glyoxalase-2 Activity Assay}

Glyoxalase-2 (Glo-2) activity was measured in protein homogenates of the spinal cord and brain as previously described by Arai et al. [27]. The activity assay mix consisted of $0.3 \mathrm{mM}$ S-D-Lactoylglutathione (Sigma-Aldrich, Saint Louis, MO, USA) diluted in a $50 \mathrm{mM}$ Tris- $\mathrm{HCl}$ buffer ( $\mathrm{pH}$ 7.4). Using a spectrophotometry analysis, Glo-2 activity was determined as the degradation of S-D-Lactoylglutathione measured at an absorbance of $240 \mathrm{~nm}$ during $30 \mathrm{~min}$.

\section{Statistical analysis}

Data is presented as mean \pm SEM. Statistical analysis was performed with GraphPad Prism version 7 (GraphPad Software, La Jolla, CA, USA). Data is analyzed using unpaired t-test and two-way ANOVA with Sidak's multiple comparisons post-test. A P $\leq 0.05$ was considered statistically significant.

\section{Results}

\section{EAE induces the formation of AGEs in the CNS}

To investigate whether the a-dicarbonyls MGO, GO and 3DG and AGEs CML, CEL and MG-H1 are increased during EAE, we subjected mice to EAE and compared the levels in the plasma, spinal cord and brain with levels of healthy agematched control mice. MGO, GO and 3DG were significantly decreased in the plasma of mice subjected to EAE (Table 3.1). Yet, we observed significantly increased levels of free MG-H1 in the plasma of mice subjected to EAE compared to healthy controls (Table 3.1). Protein-bound CML, CEL and MG-H1 were unchanged in the plasma of EAE mice compared to the healthy controls (Table 3.1).

In the spinal cord, the major site of inflammation during $E A E, M G O$ levels were significantly increased and $G O$ levels tended to be increased $(p=0.09)$ (Table 3.1). Free CML, CEL and MG-H1, but not protein-bound CML, CEL and MG-H1, were significantly increased in the spinal cord of mice subjected to EAE (Table 3.1). To determine whether the main MGO detoxification enzyme is affected during EAE, Glo-1 activity was determined in the spinal cord. Glo-1 activity was significantly reduced in the spinal cord of mice subjected to EAE compared to their healthy WT controls (Table 3.1). Glo-2 activity was equal between the groups (data not shown). 
MGO and GO levels were also significantly increased in the brain of mice subjected to EAE (Table 3.1). In addition, free CML was increased in the brain whereas free CEL and MG-H1 remained unchanged. Protein-bound CML, CEL and MG-H1 was also not altered in the brain of mice subjected to EAE compared to healthy controls (Table 3.1). Glo-1 activity in the brain however was increased in the EAE mice (Table 3.1). Glo-2 activity between the two groups was not significantly altered due to EAE (data not shown).

\section{PM intervention did not reduce $A G E$ levels in the plasma and spinal cord during EAE}

To investigate whether inhibition of AGE formation attenuates disease progression in an animal model of MS, mice were treated with $10 \mathrm{~g} / \mathrm{L}$ PM via oral gavage during EAE. PM is described as a dicarbonyl scavenger, thereby reducing AGE levels [23]. The control group was treated with vehicle. Analysis of plasma and spinal cord of mice treated with PM and vehicle showed that dicarbonyls, free AGEs and protein-bound AGEs were not altered in the PM treated group compared to the vehicle treated group after EAE (Table 3.2). Glo-1 activity in the spinal cord was not altered between the groups (Table 3.2). In line, PM treatment did no lead to differences in weight and disease progression, measured by EAE score, compared to vehicle treated controls (Figure 3.1A, B).

\section{Human Glo-1 overexpression mouse model did not reduce AGEs levels in the plasma and CNS during EAE}

$10 \mathrm{~g} / \mathrm{L}$ PM treatment was unable to reduce dicarbonyl and AGE levels in the plasma and central nervous system. As an alternative mouse model to lower AGEs during EAE development, the Glo-1 overexpression mouse model was used. In this mouse model, the human Glo-1 gene is inserted under the control of the beta-actin promoter, leading to a full body overexpression of the Glo-1 enzyme. Wild type litter mates were used as a control group. EAE was induced in both Glo-1 overexpression mice and wild type mice.

Glo-1 activity was assessed in the CNS of the Glo-1 overexpression and wild type mice after EAE. Glo-1 activity was 5.5 and 5.9 times increased in respectively the spinal cord and brain of Glo-1 overexpression mice compared to their wild type littermates (Table 3.3). However, dicarbonyl levels and free and protein-bound AGE levels in the plasma, spinal cord and brain were similar after EAE (Table 3.3). In line with this, weight reduction and clinical EAE score were not altered in the Glo-1 overexpression mice compared to the wild type controls (Figure 3.2A, B). 
Table 3.1. a-Dicarbonyls, free AGEs and protein-bound $(\mathrm{Pb})$ AGEs in the plasma, spinal cord, and brain of mice subjected to EAE and healthy controls. Data presented as mean \pm SEM and analysed using unpaired t-test.

Healthy $\quad$ EAE -value

$\mathrm{n}=8$

$\mathrm{n}=8$

\begin{tabular}{|c|c|c|c|}
\hline \multicolumn{4}{|l|}{ Plasma } \\
\hline MGO (nmol) & $3268 \pm 378,2$ & $2160 \pm 230,3$ & 0.03 \\
\hline $\mathrm{GO}(\mathrm{nmol})$ & $1414 \pm 50,7$ & $1205 \pm 69,8$ & 0.03 \\
\hline 3DG (nmol) & $2051 \pm 123,0$ & $1611 \pm 151,6$ & 0.04 \\
\hline $\mathrm{Pb}$ CML (nmol/mmol Lysine) & $25,55 \pm 1,1$ & $25,18 \pm 1,4$ & 0.83 \\
\hline $\mathrm{Pb}$ CEL (nmol/mmol Lysine) & $9,088 \pm 0,7$ & $8,350 \pm 1,2$ & 0.60 \\
\hline Pb MG-H1 (nmol/mmol Lysine) & $276,5 \pm 18,7$ & $285,6 \pm 17,2$ & 0.73 \\
\hline Free CML (nmol) & $315,4 \pm 17,1$ & $283,6 \pm 14,9$ & 0.18 \\
\hline Free CEL (nmol) & $98,06 \pm 6,5$ & $99,88 \pm 9,3$ & 0.88 \\
\hline Free MG-H1 (nmol) & $59,61 \pm 5,9$ & $91,54 \pm 5,7$ & 0.002 \\
\hline \multicolumn{4}{|l|}{ Spinal cord } \\
\hline MGO (nmol) & $1980 \pm 169,4$ & $3143 \pm 418,6$ & 0.02 \\
\hline $\mathrm{GO}(\mathrm{nmol})$ & $1706 \pm 249,8$ & $2258 \pm 164,5$ & 0.09 \\
\hline $\mathrm{Pb}$ CML (nmol/mmol Lysine) & $297,5 \pm 116,1$ & $187,2 \pm 15,7$ & 0.36 \\
\hline $\mathrm{Pb}$ CEL (nmol/mmol Lysine) & $65,08 \pm 16,2$ & $37,36 \pm 2,1$ & 0.11 \\
\hline Pb MG-H1 (nmol/mmol Lysine) & $159,4 \pm 10,4$ & $165,3 \pm 13,6$ & 0.73 \\
\hline Free CML (nmol) & $60,96 \pm 2,3$ & $98,08 \pm 7,9$ & 0.0005 \\
\hline Free CEL (nmol) & $14,63 \pm 0,4$ & $18,06 \pm 1$ & 0.01 \\
\hline Free MG-H1 (nmol) & $3,350 \pm 0,07$ & $5,471 \pm 0,8$ & 0.01 \\
\hline Glo-1 activity (nmol/mg/min) & $262,5 \pm 8,9$ & $198,9 \pm 14,3$ & 0.002 \\
\hline \multicolumn{4}{|l|}{ Brain } \\
\hline MGO (nmol) & $1222 \pm 162,2$ & $2302 \pm 299,3$ & 0.01 \\
\hline GO (nmol) & $1833 \pm 169,4$ & $2250 \pm 88,5$ & 0.05 \\
\hline $\mathrm{Pb}$ CML (nmol/mmol Lysine) & $91,49 \pm 4,6$ & $98,74 \pm 6,1$ & 0.36 \\
\hline $\mathrm{Pb}$ CEL (nmol/mmol Lysine) & $42,64 \pm 2,1$ & $43,73 \pm 3,1$ & 0.77 \\
\hline Pb MG-H1 (nmol/mmol Lysine) & $129,5 \pm 15,8$ & $139,4 \pm 19,2$ & 0.70 \\
\hline Free CML (nmol) & $55,48 \pm 1,8$ & $73,88 \pm 2,7$ & $<0,0001$ \\
\hline Free CEL (nmol) & $24,64 \pm 0,8$ & $25,29 \pm 1,4$ & 0.69 \\
\hline Free MG-H1 (nmol) & $3,538 \pm 0,2$ & $4,000 \pm 0,3$ & 0.19 \\
\hline Glo-1 activity (nmol/mg/min) & $147,9 \pm 5,2$ & $161,4 \pm 2,9$ & 0.04 \\
\hline
\end{tabular}


A

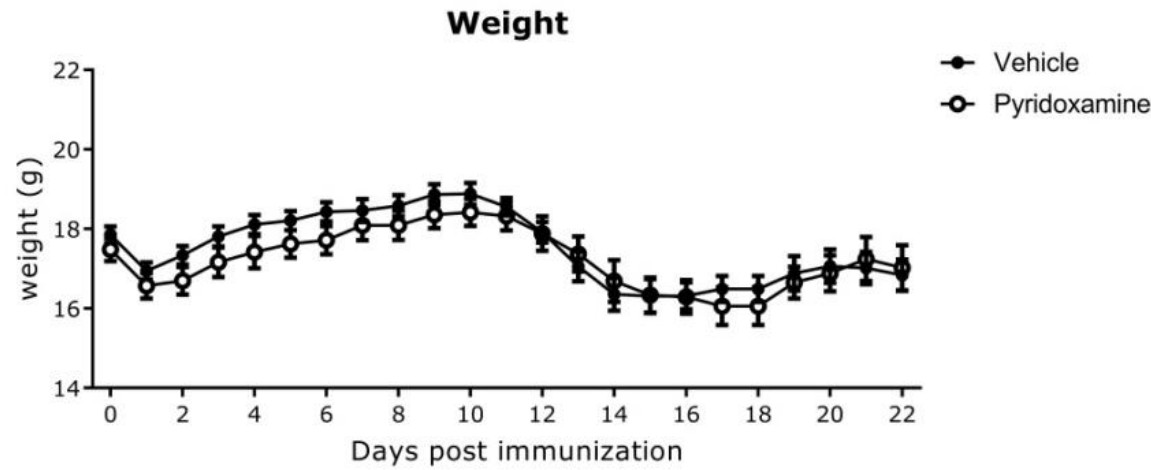

B

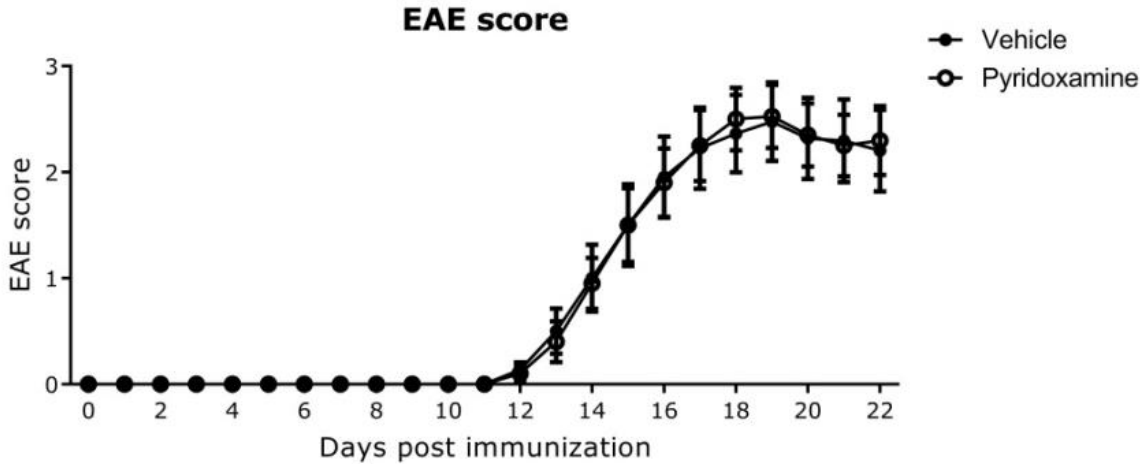

Figure 3.1. $10 \mathrm{~g} / \mathrm{L}$ Pyridoxamine does not affect EAE disease outcome. Mice were immunized with myelin oligodendrocyte glycoprotein (MOG) to induce EAE and treated with either vehicle or $10 \mathrm{~g} / \mathrm{L}$ pyridoxamine. Vehicle $(n=11)$ and $10 \mathrm{~g} / \mathrm{L}$ pyridoxamine $(n=$ 10) treated mice were weighed (a) and scored (b) daily for 22 days after EAE induction. Closed circles $(\bullet)$ represent vehicle treated mice and open circles (o) represent $10 \mathrm{~g} / \mathrm{L}$ pyridoxamine treated mice. Data is presented as mean \pm SEM and analysed using twoway analysis of variance (ANOVA) with Sidak's multiple comparisons post-test. 
Table 3.2. a-Dicarbonyl and AGE levels in the plasma and spinal cord after daily oral vehicle or pyridoxamine $(10 \mathrm{~g} / \mathrm{L})$ treatment during EAE. Data presented as mean \pm SEM and analysed using unpaired t-test.

Control Pyridoxamine p-value

$\mathrm{n}=11$ $\mathrm{n}=10$

\section{Plasma}

MGO (nmol)

$2270 \pm 207,7 \quad 2488 \pm 226,7 \quad 0.49$

$\mathrm{GO}(\mathrm{nmol})$

$1447 \pm 159,2 \quad 1391 \pm 90,9 \quad 0.77$

3DG (nmol)

$1496 \pm 89,16 \quad 1642 \pm 44,2 \quad 0.17$

$\mathrm{Pb}$ CML (nmol/mmol Lysine)

$19,72 \pm 1 \quad 19,99 \pm 1,6 \quad 0.89$

$\mathrm{Pb}$ CEL (nmol/mmol Lysine)

$5,318 \pm 0,4 \quad 4,740 \pm 0,3 \quad 0.31$

$\mathrm{Pb}$ MG-H1 (nmol/mmol Lysine)

$217,0 \pm 11,5 \quad 239,2 \pm 15,29 \quad 0.25$

Free CML (nmol)

$364,5 \pm 136,7 \quad 218,4 \pm 10,2 \quad 0.32$

Free CEL (nmol)

Free MG-H1 (nmol)

$138,8 \pm 69,8 \quad 71,56 \pm 5,5 \quad 0.37$

$96,60 \pm 37,3 \quad 63,58 \pm 7,1 \quad 0.42$

\section{Spinal cord}

MGO (nmol)

$1976 \pm 177,0 \quad 1977 \pm 131,5 \quad 1.00$

$\mathrm{GO}(\mathrm{nmol})$

$2117 \pm 122,4 \quad 2207 \pm 150,3 \quad 0.65$

$\mathrm{Pb}$ CML (nmol/mmol Lysine)

$97,58 \pm 12 \quad 95,93 \pm 12,1 \quad 0.92$

$\mathrm{Pb}$ CEL (nmol/mmol Lysine)

$50,15 \pm 4,4 \quad 52,22 \pm 4,6 \quad 0.75$

$\mathrm{Pb}$ MG-H1 (nmol/mmol Lysine)

$108,3 \pm 11,3$

$132,1 \pm 17$

0.25

Free CML (nmol)

$92,90 \pm 5,4$

$97,25 \pm 4,7$

0.56

Free CEL (nmol)

$17,56 \pm 0,4$

$17,91 \pm 0,5$

0.59

Free MG-H1 (nmol)

$4,491 \pm 0,2$

$4,760 \pm 0,3$

0.43

Glo-1 activity ( $\mathrm{nmol} / \mathrm{mg} / \mathrm{min}$ )

$1614 \pm 46$

$1572 \pm 59,2$

0.58 
A

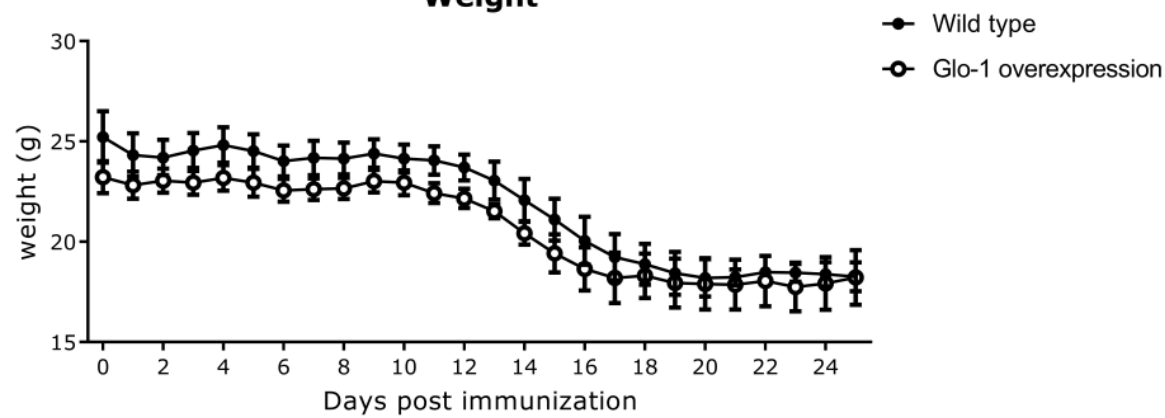

B

\section{EAE score}

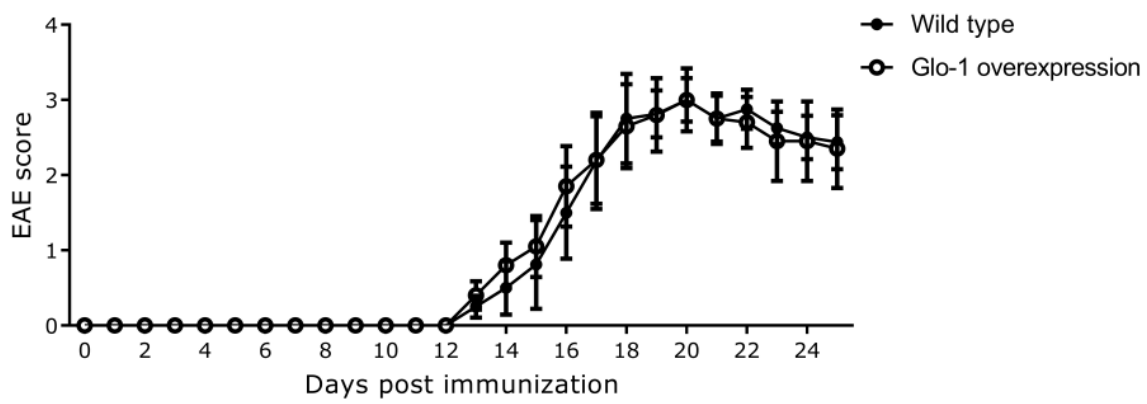

Figure 3.2. Full body Glo-1 overexpression does not affect EAE disease outcome. Glo-1 overexpression mice and wild type littermates were immunized with MOG to induce EAE. Wild type $(n=4)$ and Glo-1 overexpression $(n=5)$ mice were weighed (a) and scored (b) daily for 25 days after EAE induction. Closed circles $(\bullet)$ represent wild type littermates and open circles ( $\circ$ ) represent Glo-1 overexpression mice. Data is presented as mean \pm SEM and analysed using two-way ANOVA with Sidak's multiple comparisons posttest. 
Table 3.3. a-Dicarbonyl and AGE levels in the plasma and CNS of full body Glo-1 overexpression mice and wild type littermates after EAE. Data presented as mean \pm SEM and analysed using unpaired t-test.

\section{Wild type \\ Glo-1 transgenic p-value}

$\mathrm{n}=4$

$\mathrm{n}=5$

\section{Plasma}

MGO (nmol)

$\mathrm{GO}(\mathrm{nmol})$

3DG (nmol)

$\mathrm{Pb}$ CML (nmol/mmol Lysine)

$\mathrm{Pb}$ CEL ( $\mathrm{nmol} / \mathrm{mmol}$ Lysine)

$\mathrm{Pb}$ MG-H1 (nmol/mmol Lysine)

Free CML (nmol)

Free CEL (nmol)

Free MG-H1 (nmol)

\section{Spinal cord}

MGO (nmol)

$\mathrm{GO}(\mathrm{nmol})$

$\mathrm{Pb}$ CML (nmol/mmol Lysine)

$\mathrm{Pb}$ CEL ( $\mathrm{nmol} / \mathrm{mmol}$ Lysine)

$\mathrm{Pb}$ MG-H1 (nmol/mmol Lysine)

Free CML (nmol)

Free CEL (nmol)

Free MG-H1 (nmol)

Glo-1 activity ( $\mathrm{nmol} / \mathrm{mg} / \mathrm{min}$ )

\section{Brain}

\author{
MGO (nmol) \\ $\mathrm{GO}(\mathrm{nmol})$ \\ $\mathrm{Pb}$ CML (nmol/mmol Lysine) \\ $\mathrm{Pb}$ CEL (nmol/mmol Lysine) \\ $\mathrm{Pb}$ MG-H1 (nmol/mmol Lysine) \\ Free CML (nmol) \\ Free CEL (nmol) \\ Free MG-H1 (nmol) \\ Glo-1 activity ( $\mathrm{nmol} / \mathrm{mg} / \mathrm{min}$ )
}

$\begin{array}{lll}1837 \pm 577,7 & 3279 \pm 431,7 & 0.08 \\ 1047 \pm 44,2 & 1477 \pm 338,8 & 0.30 \\ 1690 \pm 171,5 & 2125 \pm 166,9 & 0.11 \\ 25,90 \pm 0,8 & 26,87 \pm 1,6 & 0.64 \\ 6,247 \pm 1 & 8,757 \pm 0,8 & 0.08 \\ 307,9 \pm 51,2 & 274,0 \pm 15,3 & 0.50 \\ 251,1 \pm 28,1 & 790,4 \pm 522,9 & 0.39 \\ 72,68 \pm 15,4 & 330,4 \pm 250,4 & 0.39 \\ 64,00 \pm 8,2 & 169,1 \pm 114,1 & 0.44\end{array}$

$3865 \pm 500,3 \quad 3382 \pm 183,6 \quad 0.35$

$2794 \pm 630 \quad 2517 \pm 219,8 \quad 0.66$

$108,4 \pm 4.4 \quad 102,3 \pm 7,7 \quad 0.54$

$41,91 \pm 5,7 \quad 46,45 \pm 8,5 \quad 0.69$

$270,7 \pm 24,8 \quad 305,4 \pm 47,3 \quad 0.57$

$87,33 \pm 9,3 \quad 92,88 \pm 7,2 \quad 0.64$

$17,05 \pm 0,8 \quad 16,44 \pm 0,5 \quad 0.53$

$4,425 \pm 0,8 \quad 3,700 \pm 0,1 \quad 0.32$

$66,58 \pm 8,1 \quad 367,8 \pm 6,4 \quad<0,0001$

$\begin{array}{lll}2906 \pm 308,9 & 2836 \pm 126,9 & 0.83 \\ 4086 \pm 718,3 & 4291 \pm 353,9 & 0.79 \\ 63,85 \pm 4,3 & 57,77 \pm 6,7 & 0.50 \\ 40,59 \pm 5,8 & 36,98 \pm 2,3 & 0.55 \\ 177,3 \pm 15,5 & 179,4 \pm 12,6 & 0.92 \\ 52,00 \pm 4,6 & 51,20 \pm 2,9 & 0.88 \\ 25,35 \pm 1,7 & 25,42 \pm 1,1 & 0.97 \\ 3,275 \pm 0,1 & 3,400 \pm 0,2 & 0.69 \\ 50,05 \pm 2,1 & 296,1 \pm 11 & <0,0001\end{array}$




\section{Discussion}

Our study shows that levels of dicarbonyls and AGEs are significantly increased in the CNS of mice subjected to EAE. Moreover, Glo-1 activity in the spinal cord was significantly decreased whereas Glo-1 is increased in the brain. Therapeutic approaches to reduce AGE levels using PM and human Glo-1 overexpression failed to reduce AGE levels in the plasma and CNS of EAE mice, which was paralleled with unchanged neurological scores.

EAE progression leads to a decrease of plasma levels of MGO, GO and 3DG but an increase of free MG-H1 compared to healthy controls. The decrease in dicarbonyl levels in the plasma could indicate that plasma MGO, GO and 3DG are able to pass the blood brain barrier and accumulate in the spinal cord. Here, dicarbonyls are able to induce the formation of free CML, CEL and MG-H1 since $\mathrm{GO}$ and 3DG lead to the formation of $\mathrm{CML}$, whereas MGO leads to the formation of CEL and MG-H1. We have found increased levels of CML, CEL and MG-H1 in the spinal cord of mice subjected to EAE. This suggests that plasma dicarbonyls enter the CNS and leads to a decrease in the plasma and increased formation of AGEs in the CNS. Moreover, MGO, GO, free CML, CEL and MG-H1 are increased in the spinal cord of EAE mice compared to healthy animals. We also observed decreased Glo-1 activity levels in the spinal cord. The increase of AGEs in the spinal cord may be due to the combination of infiltration and activation of immune cells and decreased Glo-1 activity. The activation of microglia and infiltrated macrophages leads to an induction of glycolysis [8, 9], probably resulting in the formation of MGO and GO. Moreover, Bogie et al. showed that phagocytosis of myelin by macrophages induces genes involved in glycolysis [28], also potentially contributing to local MGO production. In addition, Hanssen et al. revealed that inflammatory cytokine TNF reduces Glo-1 activity in U937 monocytes in vitro [13], suggesting that the pro-inflammatory environment in the spinal cord of EAE mice contributes to the decrease in Glo-1 activity and the concomitant increase in AGE levels.

In contrast to the spinal cord, in the brain only MGO, GO and CML were significantly increased and Glo-1 activity was even increased compared to healthy controls. Since Glo-1 detoxifies MGO and prevents the formation of MGO-derived AGEs such as CEL and MG-H1, this explains why CEL and MG-H1 were not increased in the brain of EAE mice. In addition, inflammatory demyelinating lesions are more abundant in the spinal cord compared to the brain of the EAE model [29]. It is therefore conceivable that inflammationinduced AGE production is of more importance in the spinal cord compared to the brain.

AGEs are known to bind to their receptor RAGE resulting in NF-KB activation and subsequent production of pro-inflammatory cytokines [12]. Lowering of AGE levels in the spinal cord during EAE could therefore reduce inflammation and neurological disease progression. Indeed, Yan et al. have shown that prevention 
of RAGE activation by soluble RAGE (SRAGE) and inhibition of RAGE activation on $\mathrm{CD}^{+}{ }^{+} \mathrm{T}$-cells leads to a decreased EAE disease progression [30]. These results suggest that lowering RAGE ligands could ameliorate neuroinflammatory responses.

One potential AGE lowering substance is pyridoxamine (PM). PM is one of the three natural vitamin B6 vitamers along with pyridoxine and pyridoxal. PM is described to lower AGEs by scavenging dicarbonyls such as MGO [31]. Foodderived PM is absorbed in the intestine by means of passive diffusion [32]. After uptake, PM is converted into pyridoxamine-5'-phosphate and further into pyridoxal-5'-phosphate in the intestine and liver [33, 34]. Sakurai et al. found that supplementation with higher concentrations of labelled [3H]PM (140 nmol) resulted in a significant amount of labelled PM, pyridoxal and pyridoxal-5'phosphate in the plasma [33, 34]. In our current study, we have administered $0.5 \mathrm{ml}$ of $10 \mathrm{~g} / \mathrm{L} \mathrm{PM}$ via oral gavage twice daily which results in a concentration of $59.5 \mathrm{mmol}$ daily which is significantly higher compared to Sakurai et al.. Moreover, van der Ham et al. developed a UPLC MSMS method for the quantification of the vitamin B6 vitamers PM, pyridoxine and pyridoxal and has proven that pyridoxine supplementation increases the levels of all three vitamers including PM in the cerebrospinal fluid of these persons [35], indicating that the free form of PM, but also pyridoxine and pyridoxal, are able to cross the bloodbrain barrier thereby entering the cerebrospinal fluid (CSF). Subsequently, brain cells are capable of active uptake of PM and the other two forms from the CSF [36]. PM supplementation for 24 weeks has been proven to reduce AGE levels in clinical trials studying osteoarthritis and diabetic nephropathy [37, 38]. Moreover, we have previously shown that PM treatment inhibits adipose tissue expansion and -induced adipose tissue inflammation, indicating that PM is capable to reduce inflammation in vivo using a 5 times lower dose [39]. However, in this current study, we have found that PM was not capable to affect AGE levels in the plasma and spinal cord during $E A E$, which may be due to the severity of the animal model of MS which possibly limits major decreases in AGE formation. Nevertheless, it may be possible that the metabolic improvements shown in our previous study were secondary to the lowering of AGEs. PM is known to have multiple effects including the reduction of oxidative stress [23, 31]. This might be the primary mechanism of action, contributing to decreased adipose tissue inflammation, as we have shown previously. Yet, it seems that the primary effects of PM is less relevant in the EAE model as we do not observe any effects on EAE severity and AGE levels.

We found that Glo-1 activity is significantly reduced in the spinal cord of mice subjected to EAE compared to healthy controls. Since Glo-1 is the major enzyme involved in the detoxification of MGO and thereby preventing the formation of AGEs, we have used Glo-1 overexpression mice. The inserted human Glo-1 is under the control of the $\beta$-actin promoter [24], and in the CNS, microglia are the main cells with high $\beta$-actin transcription [40], suggesting that microglia have 
high overexpression of Glo-1 resulting in a high capacity to detoxify MGO and prevent AGE formation. Although we confirmed that Glo-1 overexpressing mice have approximately 5.5-5.9 times higher Glo-1 activity in brain and spinal cord compared to their wild type littermates, we observed equal dicarbonyl and AGE levels in Glo-1 overexpressing and wild type littermates. The detoxification of MGO via the glyoxalase pathway requires GSH as the initial step of the pathway [41]. It has previously been shown that GSH levels are reduced in the acute phase of EAE $[42,43]$. It is therefore possible that, due to decreased availability of GSH in the spinal cord of mice subjected to $E A E$, Glo-1 overexpression may not result in increased Glo-1 activity in vivo.

In conclusion, we have revealed that dicarbonyl and AGE levels are increased in the experimental animal model of MS. This may suggest that similar pathways are activated in MS patients, as recently reviewed [44]. However, we were unable to reduce AGE levels by PM treatment and a Glo-1 overexpression in the EAE model. This model is an acute model which mimics the initial response in MS patients. Nevertheless, MS is a chronic disease with several disease phases and underlying disease pathologies which are not all simulated in the acute EAE model. Therefore, we cannot exclude the possibility that AGE lowering therapies could be beneficial for MS patients. 


\section{References}

1. Compston, A. and A. Coles, Multiple sclerosis. Lancet, 2008. 372(9648): p. 150217.

2. Ellwardt, E. and F. Zipp, Molecular mechanisms linking neuroinflammation and neurodegeneration in MS. Exp Neurol, 2014. 262 Pt A: p. 8-17.

3. Hemmer, B., M. Kerschensteiner, and T. Korn, Role of the innate and adaptive immune responses in the course of multiple sclerosis. Lancet Neurol, 2015. 14(4): p. 406-19.

4. Bogie, J.F., P. Stinissen, and J.J. Hendriks, Macrophage subsets and microglia in multiple sclerosis. Acta Neuropathol, 2014. 128(2): p. 191-213.

5. Mix, E., et al., Animal models of multiple sclerosis--potentials and limitations. Prog Neurobiol, 2010. 92(3): p. 386-404.

6. Procaccini, C., et al., Animal models of Multiple Sclerosis. Eur J Pharmacol, 2015. 759: p. 182-91.

7. Baker, D. and S. Amor, Experimental autoimmune encephalomyelitis is a good model of multiple sclerosis if used wisely. Mult Scler Relat Disord, 2014. 3(5): p. 555-64.

8. Kelly, B. and L.A. O'Neill, Metabolic reprogramming in macrophages and dendritic cells in innate immunity. Cell Res, 2015. 25(7): p. 771-84.

9. Orihuela, R., C.A. McPherson, and G.J. Harry, Microglial M1/M2 polarization and metabolic states. Br J Pharmacol, 2016. 173(4): p. 649-65.

10. Allaman, I., M. Belanger, and P.J. Magistretti, Methylglyoxal, the dark side of glycolysis. Frontiers in Neuroscience, 2015. 9.

11. Vistoli, G., et al., Advanced glycoxidation and lipoxidation end products (AGES and ALES): an overview of their mechanisms of formation. Free Radic Res, 2013. 47 Suppl 1: p. 3-27.

12. Brownlee, M., Biochemistry and molecular cell biology of diabetic complications. Nature, 2001. 414(6865): p. 813-20.

13. Hanssen, N.M., et al., Higher levels of advanced glycation endproducts in human carotid atherosclerotic plaques are associated with a rupture-prone phenotype. Eur Heart J, 2014. 35(17): p. 1137-46.

14. van Eupen, M.G., et al., The methylglyoxal-derived AGE tetrahydropyrimidine is increased in plasma of individuals with type 1 diabetes mellitus and in atherosclerotic lesions and is associated with sVCAM-1. Diabetologia, 2013. 56(8): p. 1845-55.

15. Gaens, K.H., et al., Nepsilon-(carboxymethyl)lysine-receptor for advanced glycation end product axis is a key modulator of obesity-induced dysregulation of adipokine expression and insulin resistance. Arterioscler Thromb Vasc Biol, 2014. 34(6): p. 1199-208.

16. Gaens, K.H., et al., Endogenous formation of Nepsilon-(carboxymethyl)lysine is increased in fatty livers and induces inflammatory markers in an in vitro model of hepatic steatosis. J Hepatol, 2012. 56(3): p. 647-55.

17. Stitt, A.W., et al., Advanced glycation end products (AGES) co-localize with AGE receptors in the retinal vasculature of diabetic and of AGE-infused rats. Am J Pathol, 1997. 150(2): p. 523-31.

18. Ahmed, N., et al., Protein glycation, oxidation and nitration adduct residues and free adducts of cerebrospinal fluid in Alzheimer's disease and link to cognitive impairment. J Neurochem, 2005. 92(2): p. 255-63.

19. Dalfo, E., et al., Evidence of oxidative stress in the neocortex in incidental Lewy body disease. J Neuropathol Exp Neurol, 2005. 64(9): p. 816-30.

20. Sternberg, Z., et al., Diagnostic potential of plasma carboxymethyllysine and carboxyethyllysine in multiple sclerosis. J Neuroinflammation, 2010. 7: p. 72.

21. Sternberg, Z., et al., AGE-RAGE in multiple sclerosis brain. Immunol Invest, 2011. 40(2): p. 197-205.

22. Maessen, D.E., C.D. Stehouwer, and C.G. Schalkwijk, The role of methylglyoxal and the glyoxalase system in diabetes and other age-related diseases. Clin Sci (Lond), 2015. 128(12): p. 839-61. 
23. Voziyan, P.A. and B.G. Hudson, Pyridoxamine: the many virtues of a maillard reaction inhibitor. Ann N Y Acad Sci, 2005. 1043: p. 807-16.

24. Inagi, R., et al., Efficient in vitro lowering of carbonyl stress by the glyoxalase system in conventional glucose peritoneal dialysis fluid. Kidney Int, 2002. 62(2): p. $679-87$.

25. Hanssen, N.M., et al., Plasma levels of advanced glycation endproducts Nepsilon(carboxymethyl)lysine, Nepsilon-(carboxyethyl)lysine, and pentosidine are not independently associated with cardiovascular disease in individuals with or without type 2 diabetes: the Hoorn and CODAM studies. J Clin Endocrinol Metab, 2013. 98(8): p. E1369-73.

26. McLellan, A.C., S.A. Phillips, and P.J. Thornalley, The assay of S-Dlactoylglutathione in biological systems. Anal Biochem, 1993. 211(1): p. 37-43.

27. Arai, M., et al., Measurement of glyoxalase activities. Biochem Soc Trans, 2014. 42(2): p. 491-4.

28. Bogie, J.F., et al., Myelin-derived lipids modulate macrophage activity by liver $X$ receptor activation. PLoS One, 2012. 7(9): p. e44998.

29. Simmons, S.B., D. Liggitt, and J.M. Goverman, Cytokine-regulated neutrophil recruitment is required for brain but not spinal cord inflammation during experimental autoimmune encephalomyelitis. J Immunol, 2014. 193(2): p. 55563.

30. Yan, S.S., et al., Suppression of experimental autoimmune encephalomyelitis by selective blockade of encephalitogenic T-cell infiltration of the central nervous system. Nat Med, 2003. 9(3): p. 287-93.

31. Voziyan, P.A. and B.G. Hudson, Pyridoxamine as a multifunctional pharmaceutical: targeting pathogenic glycation and oxidative damage. Cell Mol Life Sci, 2005. 62(15): p. 1671-81.

32. Hamm, M.W., H. Mehansho, and L.M. Henderson, Transport and metabolism of pyridoxamine and pyridoxamine phosphate in the small intestine of the rat. J Nutr, 1979. 109(9): p. 1552-9.

33. Sakurai, T., et al., Absorption and metabolism of pyridoxamine in mice. $I$. Pyridoxal as the only form of transport in blood. J Nutr Sci Vitaminol (Tokyo), 1991. 37(4): p. 341-8.

34. Sakurai, T., et al., Absorption and metabolism of pyridoxamine in mice. II. Transformation of pyridoxamine to pyridoxal in intestinal tissues. J Nutr Sci Vitaminol (Tokyo), 1992. 38(3): p. 227-33.

35. van der Ham, M., et al., Quantification of vitamin $B 6$ vitamers in human cerebrospinal fluid by ultra performance liquid chromatography-tandem mass spectrometry. Anal Chim Acta, 2012. 712: p. 108-14.

36. Surtees, R., P. Mills, and P. Clayton, Inborn errors affecting vitamin B6 metabolism. Future neurology, 2006. 1(5): p. 615-620.

37. Garg, S., A. Syngle, and K. Vohra, Efficacy and tolerability of advanced glycation end-products inhibitor in osteoarthritis: a randomized, double-blind, placebocontrolled study. Clin J Pain, 2013. 29(8): p. 717-24.

38. Williams, M.E., et al., Effects of pyridoxamine in combined phase 2 studies of patients with type 1 and type 2 diabetes and overt nephropathy. Am J Nephrol, 2007. 27(6): p. 605-14.

39. Maessen, D.E., et al., Delayed Intervention With Pyridoxamine Improves Metabolic Function and Prevents Adipose Tissue Inflammation and Insulin Resistance in High-Fat Diet-Induced Obese Mice. Diabetes, 2016. 65(4): p. 95666.

40. Zhang, Y., et al., An RNA-sequencing transcriptome and splicing database of glia, neurons, and vascular cells of the cerebral cortex. J Neurosci, 2014. 34(36): p. 11929-47.

41. Rabbani, N. and P.J. Thornalley, Glyoxalase in diabetes, obesity and related disorders. Semin Cell Dev Biol, 2011. 22(3): p. 309-17.

42. Dasgupta, A., et al., Increased carbonylation, protein aggregation and apoptosis in the spinal cord of mice with experimental autoimmune encephalomyelitis. ASN Neuro, 2013. 5(1): p. e00111. 
43. Zheng, J. and O.A. Bizzozero, Accumulation of protein carbonyls within cerebellar astrocytes in murine experimental autoimmune encephalomyelitis. J Neurosci Res, 2010. 88(15): p. 3376-85.

44. Wetzels, S., et al., Methylglyoxal-Derived Advanced Glycation Endproducts in Multiple Sclerosis. Int J Mol Sci, 2017. 18(2). 


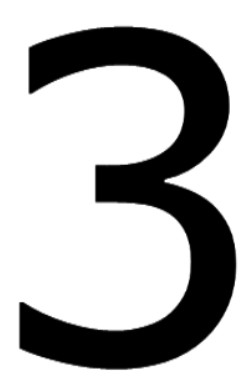

\title{
Addendum
}

\author{
Advanced glycation endproducts in the \\ cuprizone mouse model of multiple sclerosis
}


Multiple sclerosis (MS) is an inflammatory, demyelinating disease of the central nervous system (CNS) characterized by an immune response directed against the myelin, causing demyelination [1]. The EAE mouse model is the widely animal model of MS to study inflammatory mechanisms underlying disease pathology and potential therapies [2]. The model mimics the autoimmune response seen in MS patients and induces the formation of demyelinating lesions in the spinal cord. We have shown that AGEs are increased in the lesions of MS patients and in the EAE model (chapter 2 and 3) [3]. It is known that the activation of CNS-resident microglia and infiltrated macrophages switch their metabolism, favouring glycolysis [4, 5]. However it remains unknown whether AGE formation is solely due to the inflammation or whether demyelination per se also contributes to the formation of AGEs. Therefore, we determined whether demyelination due to cuprizone-induced oligodendrocyte death leads to the formation of AGEs. The cuprizone model allows us to investigate the basic processes of de- and remyelination in the absence of the infiltration of peripheral immune cells and autoimmune-mediated demyelination seen in EAE [6]. The cuprizone model relies on the cuprizone-induced apoptosis in oligodendrocytes and microglia-mediated phagocytosis of myelin debris, thereby inducing acute demyelination of the corpus callosum without massive infiltration of peripheral immune cells [7-9].

Male C57Bl/6] OlaHsd were purchased (Envigo, Venray, the Netherlands) and randomly assigned to either the control group or the cuprizone diet group. After 10 days of acclimatization, the mice ( 8 weeks old) were put on grinded standard chow or grinded standard chow supplemented with $0.3 \%$ cuprizone (SigmaAldrich, Saint Louis, USA) for 5 weeks to induce demyelination. After 5 weeks of diet, mice were euthanized with Dolethal (Val d'Hony-Verdifarm, Beringen, Belgium) and plasma and brain were isolated for further analysis. $5 \%$ protein homogenates in $0,1 \mathrm{M}$ sodium phosphate buffer $(\mathrm{pH} 6,8)$ supplemented with protease inhibitor (Roche, Basel, Switzerland) and $0,02 \%$ Triton- $x$ were made from the brain samples. The a-dicarbonyls methylglyoxal (MGO), glyoxal (GO) and 3-deoxyglucosone (3DG), and the free and protein-bound form of AGEs $\mathrm{N}^{\varepsilon_{-}}$ (carboxymethyl)lysine (CML), $\mathrm{N}^{\varepsilon}$-(1-carboxyethyl)lysine (CEL) and $\mathrm{N}^{\delta}$-(5-hydro5-methyl-4-imidazolon-2-yl)-ornithine (MG-H1) were analysed in the plasma and brain of mice using ultra-performance liquid chromatography tandem mass spectrometry (UPLC MSMS) as described previously [10, 11]. In addition, the activity of glyoxalase 1 (Glo-1), the major MGO detoxification enzyme, was determined in the brain samples as previously described [3, 12]. Data is presented as mean \pm SEM. Statistical analysis was performed with GraphPad Prism version 7 (GraphPad Software, La Jolla, USA). Data is analysed using Mann Whitney test. A $p \leq 0.05$ was considered statistically significant.

Analysis of a-dicarbonyl levels in the plasma revealed no significant changes in MGO, GO or 3DG concentrations. In the brain, MGO levels tended to be increased $(p=0.06)$, whereas GO levels tended to be decreased $(p=0.06)$ 
(Addendum Table 3.1). In line with the plasma a-dicarbonyl levels, levels of free AGEs in the plasma were equal between both groups (Addendum Table 3.1). However, in the brain, CML levels tended to be increased in the cuprizone-fed group compared to the controls $(p=0.06)$ (Addendum Table 3.1). Despite the higher levels of MGO in the brain of cuprizone-fed mice, levels of CEL and MG$\mathrm{H} 1$ remained unchanged (Addendum Table 3.1). Protein-bound AGEs and Glo-1 activity was unaltered between the control and cuprizone group (Addendum Table 3.1).

In contrast to the strong increase in AGE levels in the spinal cord of EAE mice [3], we did not observe a significant increase of AGEs in the brain of cuprizone mice compared to the controls. However, a trend towards an increase in MGO and CML levels was observed. One possible explanation might be that the lack of increased AGE levels could be due to the absence of a peripheral inflammatory response in the cuprizone model. Previous studies have revealed that CNSresident microglia and infiltrated macrophages are activated during cuprizoneinduced demyelination [13]. Peripheral macrophages are able to infiltrate the CNS, despite the intact blood-brain barrier, and accumulate in the demyelinated region $[14,15]$. Moreover, CNS-resident astrocytes increase their reactivity upon demyelination [16], and are suggested to induce the clearance of myelin debris by phagocytes [17]. This activation of microglia, macrophages and astrocytes could play a role in the trend of increased levels of MGO and CML, although the inflammatory component in the cuprizone model is much lower than the EAE model. This implies that the absence of peripheral immune cell activation and infiltration into the CNS is the major reason why AGE levels are not significantly increased in the cuprizone model.

As could be noticed, we compared the spinal cord from the EAE mice to the brain of the cuprizone mice. These two regions were selected since the spinal cord is affected in the EAE model whereas the brain is affected by the cuprizone model. The EAE model induces inflammation and thus demyelination primarily in the spinal cord. However, the cuprizone induces demyelination most prominently in the corpus callosum in the brain. Because of the different target tissues in these mouse models, we investigated the spinal cord of the EAE model and the brain in the cuprizone model. 
Addendum Table 3.1. a-Dicarbonyls, free AGEs and protein-bound (Pb) AGEs in the plasma and brain of mice subjected to the cuprizone diet and healthy controls. Data presented as mean \pm SEM and analysed using Mann Whitney test.

\begin{tabular}{|c|c|c|c|}
\hline & $\begin{array}{l}\text { Control } \\
\mathrm{n}=3\end{array}$ & $\begin{array}{l}\text { Cuprizone } \\
\mathrm{n}=4\end{array}$ & p-value \\
\hline \multicolumn{4}{|l|}{ Plasma } \\
\hline MGO (nmol) & $1337 \pm 51.2$ & $1412 \pm 389.7$ & 0.63 \\
\hline $\mathrm{GO}(\mathrm{nmol})$ & $1220 \pm 44.9$ & $1157 \pm 139$ & 0.40 \\
\hline 3DG (nmol) & $2207 \pm 142.9$ & $2030 \pm 91.2$ & 0.40 \\
\hline $\mathrm{Pb}$ CML (nmol/mmol lysine) & $31.07 \pm 6.5$ & $25.93 \pm 2.8$ & 0.63 \\
\hline $\mathrm{Pb}$ CEL (nmol/mmol lysine) & $11.47 \pm 1.5$ & $15.45 \pm 3.2$ & 0.86 \\
\hline Pb MG-H1 (nmol/mmol lysine) & $204.7 \pm 26.1$ & $222.8 \pm 22.2$ & 0.63 \\
\hline Free CML (nmol) & $347.6 \pm 58.8$ & $369.3 \pm 36.8$ & 0.63 \\
\hline Free CEL (nmol) & $160.6 \pm 13.1$ & $135.4 \pm 19.9$ & 0.40 \\
\hline Free MG-H1 (nmol) & $80.33 \pm 7.6$ & $74 \pm 5.3$ & 0.63 \\
\hline \multicolumn{4}{|l|}{ Brain } \\
\hline MGO (nmol) & $1713 \pm 223.4$ & $2616 \pm 146.3$ & 0.06 \\
\hline GO (nmol) & $2398 \pm 200.1$ & $1924 \pm 55.7$ & 0.06 \\
\hline $\mathrm{Pb}$ CML (nmol/mmol lysine) & $71.73 \pm 3.5$ & $63.63 \pm 4.6$ & 0.23 \\
\hline $\mathrm{Pb}$ CEL (nmol/mmol lysine) & $34.8 \pm 3.3$ & $31.05 \pm 1.9$ & 0.40 \\
\hline Pb MG-H1 (nmol/mmol lysine) & $140.8 \pm 15.2$ & $158.8 \pm 13.3$ & 0.40 \\
\hline Free CML (nmol) & $66.89 \pm 1.6$ & $81.95 \pm 5.2$ & 0.06 \\
\hline Free CEL (nmol) & $28.2 \pm 2.1$ & $24.98 \pm 1.3$ & 0.40 \\
\hline Free MG-H1 (nmol) & $3.73 \pm 0.1$ & $3.8 \pm 0.06$ & 0.83 \\
\hline Glo-1 activity (nmol/mg/min) & $94.3 \pm 1.3$ & $93.48 \pm 2.9$ & 0.86 \\
\hline
\end{tabular}

Taken all together, we observed that levels of AGEs remain equal between the mice subjected to the cuprizone model compared to healthy age-matched controls. The trend of increased MGO and free CML levels in the cuprizone mice could be due to infiltration and activation of macrophages, microglia and astrocytes. However, the levels of protein-bound and free CEL and MG-H1 remain equal between the mice on the cuprizone diet compared to healthy agematched controls. These data suggest that the formation of AGEs is induced by the inflammatory component of the EAE model and that the lack of this inflammatory environment in the cuprizone model limits AGE formation. However, due to the small sample size, one must be careful with the interpretation of these results. 


\section{References}

1. Compston, A. and A. Coles, Multiple sclerosis. Lancet, 2008. 372(9648): p. 150217.

2. Mix, E., et al., Animal models of multiple sclerosis--potentials and limitations. Prog Neurobiol, 2010. 92(3): p. 386-404.

3. Wetzels, S., et al., Advanced Glycation Endproducts Are Increased in the Animal Model of Multiple Sclerosis but Cannot Be Reduced by Pyridoxamine Treatment or Glyoxalase 1 Overexpression. Int J Mol Sci, 2018. 19(5).

4. Kelly, B. and L.A. O'Neill, Metabolic reprogramming in macrophages and dendritic cells in innate immunity. Cell Res, 2015. 25(7): p. 771-84.

5. Orihuela, R., C.A. McPherson, and G.J. Harry, Microglial M1/M2 polarization and metabolic states. Br J Pharmacol, 2016. 173(4): p. 649-65.

6. Procaccini, C., et al., Animal models of Multiple Sclerosis. Eur J Pharmacol, 2015. 759: p. 182-91.

7. Buschmann, J.P., et al., Inflammatory response and chemokine expression in the white matter corpus callosum and gray matter cortex region during cuprizoneinduced demyelination. J Mol Neurosci, 2012. 48(1): p. 66-76.

8. Matsushima, G.K. and P. Morell, The neurotoxicant, cuprizone, as a model to study demyelination and remyelination in the central nervous system. Brain Pathol, 2001. 11(1): p. 107-16.

9. Zendedel, A., C. Beyer, and M. Kipp, Cuprizone-induced demyelination as a tool to study remyelination and axonal protection. J Mol Neurosci, 2013. 51(2): p. 567-72.

10. Hanssen, N.M., et al., Plasma levels of advanced glycation endproducts Nepsilon(carboxymethyl)lysine, Nepsilon-(carboxyethyl)lysine, and pentosidine are not independently associated with cardiovascular disease in individuals with or without type 2 diabetes: the Hoorn and CODAM studies. J Clin Endocrinol Metab, 2013. 98(8): p. E1369-73.

11. Hanssen, N.M., et al., Higher levels of advanced glycation endproducts in human carotid atherosclerotic plaques are associated with a rupture-prone phenotype. Eur Heart J, 2014. 35(17): p. 1137-46.

12. McLellan, A.C., S.A. Phillips, and P.J. Thornalley, The assay of $S-D-$ lactoylglutathione in biological systems. Anal Biochem, 1993. 211(1): p. 37-43.

13. Rawji, K.S. and V.W. Yong, The benefits and detriments of macrophages/microglia in models of multiple sclerosis. Clin Dev Immunol, 2013. 2013: p. 948976.

14. Wergeland, S., et al., The cuprizone model: regional heterogeneity of pathology. APMIS, 2012. 120(8): p. 648-57.

15. McMahon, E.J., K. Suzuki, and G.K. Matsushima, Peripheral macrophage recruitment in cuprizone-induced CNS demyelination despite an intact blood-brain barrier. J Neuroimmunol, 2002. 130(1-2): p. 32-45.

16. Hibbits, N., et al., Astrogliosis during acute and chronic cuprizone demyelination and implications for remyelination. ASN Neuro, 2012. 4(6): p. 393-408.

17. Skripuletz, T., et al., Astrocytes regulate myelin clearance through recruitment of microglia during cuprizone-induced demyelination. Brain, 2013. 136(Pt 1): p. 147-67. 

This chapter is embargoed at request

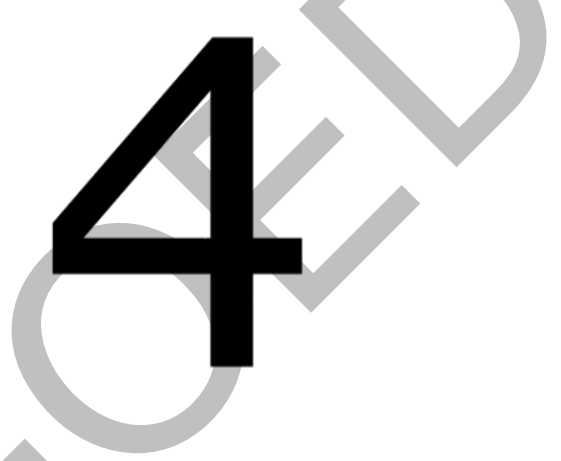

\section{Dietary methylglyoxal and advanced glycation endproducts accumulate in the central nervous system and prime towards a pro-inflammatory status}

Suzan Wetzels, Jerome J.A. Hendriks, Tim Vanmierlo, Kristiaan Wouters*, Casper G. Schalkwijk*

* These authors contributed equally to this work 
This chapter is embargoed at request

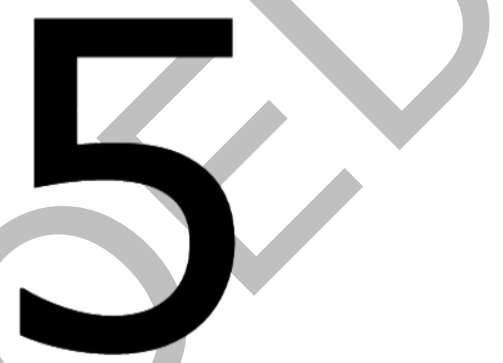

\section{Dietary methylglyoxal and advanced glycation endproducts do not aggravate disease progression in experimental autoimmune encephalomyelitis}

Suzan Wetzels, Tim Vanmierlo, Kristiaan Wouters, Casper G. Schalkwijk*, Jerome J.A. Hendriks *

* These authors contributed equally to this work 


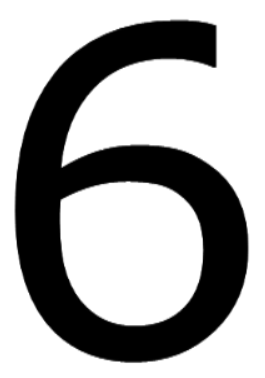

\section{Summary \& General discussion}




\section{Discussion}

Multiple sclerosis (MS) is one of the most common neurological disorders worldwide and in many countries the leading cause of non-traumatic disability related to the central nervous system (CNS) [1]. It is estimated that over 2.5 million individuals are diagnosed with MS, with numbers still increasing each year [2]. This increasing prevalence has a great impact on our health care system and leads to an increased economic burden. To this day, no cure for MS exists and MS patients are treated with disease-modifying therapies aiming to suppress the inflammatory part of the disease. In this thesis, we aimed to elucidate whether advanced glycation endproducts (AGEs), involved in many inflammatory diseases [3-11], are formed in MS and whether they influence the progression of the disease. The key findings of this thesis are discussed in this chapter.

\section{In vivo AGE formation}

MS is characterized by the infiltration of innate and adaptive immune cells in the CNS. Once in the CNS, autoreactive T-cells are reactivated by myelin-loaded macrophages and CSN-resident microglia, promoting neuroinflammation and neurodegeneration [12]. In addition to immune cells, astrocytes can sustain the neuroinflammatory environment by the production of pro-inflammatory cytokines and chemokines [13]. The activation of macrophages, CNS-resident microglia and astrocytes in the CNS can induce a cellular switch in energy substrate metabolism in favour of glycolysis [14-16]. Therefore, by-products of glycolysis, a-dicarbonyls such as methylglyoxal (MGO) and glyoxal (GO) can be produced. MGO and GO are potent glycating agents that can modify amino acids to the formation of AGEs such as CML, CEL and MG-H1 [17]. By binding to the receptor RAGE, AGEs are able to induce the production of pro-inflammatory cytokines, thereby potentially contributing to neuroinflammation. Moreover, glycation of proteins by MGO and GO can contribute to altered protein function. Finally, extracellular matrix proteins can be affected by MGO and GO which can result in altered interactions between proteins and cells. An overview of AGE production, biological effects and AGEs in MS is given in chapter $\mathbf{1}$.

\section{In vivo AGE formation in MS patients}

In chapter 2, we determined whether AGEs were present in post-mortem samples of MS lesions compared to white matter of non-demented controls (NDCs). We found increased levels of protein-bound MG-H1 in MS lesions, whereas protein-bound CML and CEL were unaffected. These data suggest that MGO reacts more easily with arginine compared to lysine as the reaction of MGO and $\mathrm{GO}$ with lysine results in the formation of CEL and CML, respectively.

We also determined whether MG-H1 levels differ between active, chronic active and chronic inactive lesions. However, we did not observe differences in proteinbound MG-H1 content between the different lesions types (data not shown). These data suggest that MG-H1 accumulation is not restricted to active MS 
lesions but is also ongoing in chronic lesions resulting in increased MG-H1 levels in all types of MS lesions compared to the white matter of NDCs. Chronic lesions are characterized by astrogliosis which is a complex response in the CNS to tissue damage resulting in reactive astrocytes that cluster together to form a glial scar [18, 19]. This activation of reactive astrocytes in the chronic lesions could be the mechanism that attributes to the increased levels of protein-bound MG-H1. As has been clearly shown for macrophages, activation of CNS resident microglia leads to a metabolic switch toward glucose utilisation (glycolysis) [15, 16]. In addition to this metabolic switch, it is also known that phagocytosis induces glycolysis in macrophages [20]. Together, this suggests that the neuroinflammatory environment in the CNS during MS contributes to the formation of AGEs. In chapter 2, we aimed to determine which specific cell type is responsible for the increased levels of MG-H1 that we observed in MS lesions. Fluorescent double staining revealed that MGO-derived AGEs are mainly present in $\mathrm{GFAP}^{+}$astrocytes. Iba $1^{+}$macrophages/microglia were rarely positive for $\mathrm{MGO}$ derived AGE. Indeed, astrocytes mainly depend on glycolysis for their energy requirement [17]. In accordance with the findings of Barateiro et al. [21], we found that RAGE was expressed on Iba1 ${ }^{+}$microglia/macrophages in MS lesions, and not on astrocytes. Although it is known that inflammation and glycolysis are closely linked in macrophages/microglia [15, 16, 22, 23], our data suggests that AGEs are produced in highly glycolytic astrocytes in contrast to inflammatory macrophages. In turn, AGEs produced by astrocytes may exert paracrine effects by RAGE activation, which is present on microglia/macrophages. RAGE activation on these phagocytes enhances the polarization towards a M1 phenotype [24], and may lead to the activation of NF-KB and the subsequent production of proinflammatory cytokines [25]. In turn, these cytokines can activate infiltrating immune cells such as macrophages and T-cells, contributing to demyelination. On the other hand, activation of RAGE also induces oxidative stress [25], which also contributes to demyelination by itself [26]. These effects include mitochondrial injury and subsequent energy failure which can induce cell apoptosis [27, 28]. Apoptosis of the oligodendrocyte, the key cell producing myelin, contributes to demyelination of the CNS. Overall, we have shown that MG-H1 is increased in human MS lesions which accumulates in astrocytes and can potentially influence the inflammatory environment of the CNS.

\section{In vivo AGE formation in the EAE model}

In chapter 3, AGE levels were investigated in the mouse model of MS, the experimental autoimmune encephalomyelitis (EAE) model. This is a commonly used mouse model which induces an autoimmune response of $\mathrm{CD}^{+}$and $\mathrm{CD}^{+} \mathrm{T}^{-}$ cells, B-cells and monocytes [29], mimicking an acute immune response in MS patients. In addition, these animals will develop demyelinated lesions, primarily in the spinal cord [30]. In contrast to the human data, we found that in the mouse model of $\mathrm{MS}$, free $\mathrm{CML}, \mathrm{CEL}$ and $\mathrm{MG}-\mathrm{H} 1$ were increased in the spinal cord, whereas the protein-bound AGE levels remain unchanged. It is known that free CML and CEL are not able to bind to RAGE [31, 32]. Protein-bound CML and 
CEL are able to bind weakly to RAGE because the protein backbone is necessary for the binding [32]. In contrast to $\mathrm{CML}$ and $\mathrm{CEL}$, both free and protein-bound MG-H1 are able to bind to RAGE [33]. Why protein-bound MG-H1 levels are increased in MS and free AGEs are increased in EAE remains unclear. It is also unclear whether the degradation of protein-bound AGEs in tissues results in increased levels of free AGEs. If this would be the case, this could suggest that protein-bound AGE breakdown is increased in the EAE model compared to the human disease, therefore leading to increased free AGE levels in the EAE model which is absent in the human disease. Moreover, one could suggest that this protein-bound AGE breakdown in the EAE model is a defence mechanism of the tissue, trying to limit the potential AGE-RAGE interaction, thereby making AGEs less relevant in the EAE model. However, we must keep in mind that MG-H1 is able to activate RAGE when in the free or in the protein-bound form. Consequently, MG-H1 could play a role in the disease progression of both MS and EAE.

There is also discrepancy between the specific AGEs formed in the mouse model and the human disease. In the EAE model, acute inflammation plays an important role, which could induce the production of CML, CEL and MG-H1. In the human samples, acute inflammation is predominantly present during relapses [34]. Whether or not the patient has experienced an inflammatory event prior to their death might interfere with the formation of CML and CEL in the lesions. Therefore, we need to be cautious with the interpretation of our results. In addition, post-mortem delay might, until freezing of the samples, play a role in the formation and/or breakdown of the different AGEs. The human samples have a post-mortem delay that take up to 720 minutes. In an experimental animal study, under controlled circumstances, post-mortem delay is no longer than 20 minutes. We could however not observe associations between a-dicarbonyl and AGE levels with post-mortem delay, probably excluding post-mortem delay as contributor for the differences seen in the human and mouse data.

\section{AGEs as potential markers of disease progression in MS}

The results of chapter $\mathbf{2}$ and $\mathbf{3}$ reveal that AGEs, free or protein-bound, are increased in MS lesions and in the spinal cord of mice subjected to EAE. In addition to the post-mortem samples, we obtained paired cerebrospinal fluid (CSF) and plasma samples of living MS patients and determined a possible correlation between plasma and CSF with respect to a-dicarbonyl and AGE levels (chapter 2). Our results show that a-dicarbonyls and free AGE levels in the CSF are significantly correlated with their respective levels in the plasma. Proteinbound AGEs in the CSF, however, are not correlated with their respective levels in the plasma. This difference could be due to the blood-CSF barrier that separates the blood and the CSF. The exchange of proteins is still possible and dependent on the molecular weight [35]. Smaller proteins or single amino acids, such as free AGEs, can easily be transported across the blood-CSF barrier. 
Bigger proteins, such as the protein-bound AGEs, are less easily transported across the blood-CSF barrier. As these results suggest that protein-bound AGEs cannot cross the blood brain barrier, they also imply that protein-bound MG-H1 formation occurs in the MS lesions.

Furthermore in chapter 2, we assessed whether a-dicarbonyl, free AGEs and protein-bound AGEs correlated with the disease severity and duration of MS. There were no positive correlations between a-dicarbonyl and AGE levels, free or protein-bound, with expanded disability status scale (EDSS), number of relapses or with disease duration. Yet, an inverse correlation was found between free MG$\mathrm{H} 1$ in the CSF and disease duration, and between protein-bound MG-H1 in the CSF and EDSS. There are factors that may influence AGE production during MS. Although we corrected for medication use, part of the study population received an anti-inflammatory therapy, which may interfere with AGE production. Moreover, whether a patient experiences a relapse at the time of sample collection could influence AGE production, as active inflammation is present during relapses. In addition, progressive MS patients, which have a higher EDSS and most often a longer disease duration, experience less relapses and thus less inflammation [34], which may result in lower MG-H1 levels in the CSF. In these patients, the interaction of AGEs with their receptor RAGE could be decreased compared to the patients in the relapsing remitting phase of the disease. Sternberg et al. revealed increased membrane-bound RAGE on monocytes and $\mathrm{CD}^{+}{ }^{+}$T-cells in RR-MS patients compared to secondary progressive MS patients [36]. These data indicate that membrane-bound RAGE, on key immune cells during MS development, plays an important role in the relapsing remitting phase of the disease. Membrane-bound RAGE is also inversely correlated with EDSS and with MS severity scale (MSSS), suggesting that RAGE may mainly affect MS during the early, highly inflammatory, period of the disease. In line with membrane-bound RAGE, Sternberg et al. revealed that soluble RAGE, which was shown to be beneficial in EAE development [37], was inversely correlated with EDSS score [38]. These data indicate that a reduction in membrane-bound RAGE may ultimately lead to less sRAGE since part of SRAGE is the product of cleaved membrane-bound RAGE by ADAM10 and MMPs [39-42]. Taken all together, our data indicate that AGEs are present in CSF and plasma of MS patients, but that their use as markers for disease progression may be limited.

\section{AGE formation as a result of inflammation}

As mentioned above, we did not find correlations between AGEs in the CSF and markers of disease progression. In line with our human data, we also did not find any correlation of a-dicarbonyl or AGE levels with EAE score in the experimental animal model (data not shown). Although inflammation is high in the EAE model, this lack of correlation could lead to the interpretation that AGE accumulation does not contribute to the pathogenesis and rather are a bystander effect of the disease. Alternatively, it is possible that the increased levels of AGEs, which we have seen in human MS lesions and the spinal cord of 
EAE mice, resides mainly intracellular. As described above, MGO-derived AGEs are mainly present in astrocytes (chapter $\mathbf{2}$ ). These observations confirm the data of Cai et al. showing that prolonged administration of oral MGO-derived AGEs results in AGE deposits in $\mathrm{GFAP}^{+}$glial cells in the brain due to AGE uptake and accumulation [43]. Taken together, our results imply that intracellular AGEs are not secreted by the astrocytes. Despite the presence of RAGE on Iba $1^{+}$ macrophages/microglia, intracellular AGE accumulation cannot activate the neighbouring cells. In turn, it could be possible that the intracellular accumulation of AGEs in astrocytes lead to altered functions of proteins, which is one of the effects of AGEs instead of RAGE activation. This could potentially alter various signalling pathways, which might contribute to a more reactive phenotype of the astrocytes and thereby influencing lesion progression. However, the effects of intracellular AGE accumulation in astrocytes needs to be further investigated. It can also be speculated that, in contrast to intracellular accumulation, AGEs are secreted by the astrocytes and bind to other AGE receptors such as AGE receptor 1 (AGER1). This AGE receptor has contradicting functions in comparison to RAGE; AGE-RAGE binding results in NF- $\mathrm{KB}$ activation, whereas AGER1 inhibits the binding of AGEs to RAGE by degrading AGEs [44]. This implies that AGEs are produced in the inflammatory environment of the CNS in MS patients and are degraded, thereby limiting their potential to induce an inflammatory phenotype in $\mathrm{RAGE}^{+}$macrophages/microglia. The exact mechanism of AGE accumulation and their potential effects need to be further elucidated.

Since AGE levels are increased in various inflammatory diseases including MS and $\operatorname{EAE}[3,4,6-11,45,46]$, we aimed to determine whether demyelination itself, without a widespread inflammatory reaction, may lead to the formation of AGEs (addendum chapter $\mathbf{3}$ ). In the brain of mice after cuprizone-induced demyelination, MGO, GO and CML levels tended to be higher, whereas CEL and MG-H1 levels were unchanged compared to controls. We did not observe significant increased levels of a-dicarbonyl and AGE in this model, as observed in the EAE model (chapter $\mathbf{3}$ ). There is activation of CNS-resident microglia and infiltrated macrophages in the cuprizone model that play both detrimental and beneficial roles during cuprizone-induced demyelination [47]. However, the level of inflammation in the cuprizone model is far less fierce compared to the EAE model. Since we did not observe significant changes of a-dicarbonyl and AGEs in the cuprizone model, it can be concluded that demyelination in itself does not lead to an increase in AGEs. Although the increase in a-dicarbonyls and AGE levels observed in MS lesions and in EAE is not correlated with disease markers, the vast majority of the a-dicarbonyls and AGEs are produced due to the inflammatory environment of the CNS. Indeed, Dhananjayan et al. has shown with an in vitro study that inflammatory stimulation of macrophages and microglia with a combination of LPS and interferon (IFN) leads to a dose- and time dependent production of MGO [48]. In line with this publication, we show in chapter $\mathbf{2}$ that inflammatory stimulation of primary human astrocytes leads to 
the production of MG-H1. On the other hand, Wang et al. revealed that stimulation of primary rat astrocytes with D-glucose-modified albumin and Dgalactose-modified album, which are often used as AGEs, leads to increased production of the pro-inflammatory cytokines IL-1 $\beta$ and TNF [49]. These results suggest that during neuroinflammation a positive feedback loop is induced in which inflammation-induced AGE formation leads to AGE-induced inflammation.

Taken together, our data indicate that the neuroinflammatory environment in the CNS of MS patients and mice subjected to EAE leads to the formation of adicarbonyls and AGEs. These AGEs could potentially enhance inflammation by inducing the production of pro-inflammatory cytokines in a RAGE-dependent manner. However, it must be noted that the direct contribution of AGEs to neuroinflammation could not be confirmed by our study.

\section{Dietary AGEs}

The formation of AGEs in food, also known as the Maillard-reaction, was first described by food chemist Louise Camille Maillard [50]. This process is slow and takes weeks before AGEs are formed. The Maillard-reaction occurs during the preparation of food which leads to a fast formation of AGEs due to heating. These AGEs are responsible for the browning of food but also increase flavour and aroma [51]. AGE content is high in typical Western type diets because of the high sugar and fat concentrations in food and due to our cooking methods such as grilling, frying, baking and toasting [52]. Although these methods will result in tasteful food, it also leads to an increased intake of dietary AGEs.

\section{Dietary AGEs in the CNS}

It has been shown previously that increased intake of dietary AGEs results in increased plasma and urine levels of AGEs in humans [53]. In chapter 4, we determined for the first time whether these dietary AGEs can accumulate in the CNS. We found that increased dietary MGO and AGE intake leads to the accumulation of free CEL and MG-H1 in both the plasma and CNS of mice. Our findings suggest that dietary AGEs are degraded in the intestine into single amino acids and absorbed, leading to increased levels of free AGEs in the plasma. Subsequently, the AGEs in plasma can enter the CNS. These results imply that free AGEs are able to cross the blood-brain barrier (BBB) which is in line with our human data showing the correlation of free AGE levels in plasma and CSF (chapter 2). In addition we showed that accumulation of free AGEs in the CNS results in the induction of pro-inflammatory genes such as MCP-1 and IL-6. This indicates that dietary AGEs have the potential to induce CNS inflammation. These data are in line with a previous study of Cai et al. who revealed that adipocytes and peritoneal macrophages have increased expression of pro-inflammatory cytokines, such as MCP-1, due to an MG-BSA-enriched diet [54]. In our study, MCP-1 and IL- 6 expression is increased and these cytokines are also known to contribute to the pathology of MS [55, 56], indicating that dietary AGE accumulation may worsen neuroinflammation in MS. 
We also determined the expression of AGER1. As mentioned above, AGER1 degrades AGEs, thereby preventing RAGE activation. AGER1 could, together with Sirt1, contribute to an anti-inflammatory environment. We found that AGER1 and Sirt1 expression was increased in the CNS of mice consuming a high dietary AGE diet for a relatively short period compared to the mice on control diet. Prolonged AGE exposure was however shown to deplete AGER1 and Sirt1, leading to hyperacetylation of NF-KB P65 [44]. Consequently, the prolonged exposure to AGEs leads to enhanced RAGE signalling including production of proinflammatory cytokines [44]. Our data imply that the intake of an AGE-rich diet affects the inflammatory state of the CNS after accumulation of AGEs. Consequently, consuming less dietary AGEs may have beneficial health effects.

\section{Dietary AGEs as modulators of EAE?}

Since we showed in chapter $\mathbf{2}$ and $\mathbf{3}$ that in MS patients and during EAE, AGE formation is increased and that dietary AGEs accumulate in the CNS (chapter 4), we hypothesized that increasing the AGE load during EAE will aggravate disease progression. In chapter 5, we investigated the effects of dietary AGEs on EAE development. The mechanism behind AGE-induced EAE aggravation could potentially be via AGE-RAGE activation. Yan et al. showed that treatment of sRAGE, which prevents the binding of ligands to RAGE, leads to the $E A E$ initiation but with significantly decreased EAE severity compared to controls [37]. On the other hand, previous research from Liliensiek et al. using full body RAGE deficiency (RAGE ${ }^{-/}$) mice did not affect EAE development [57] suggesting that RAGE is not necessary for EAE development. However, overexpression of RAGE on hematopoietic and endothelial cells led to significant increased EAE severity compared to controls. These data indicate that RAGE might play a role in the perpetuation of EAE. We found that, on top of the AGE production solely due to EAE induction, the AGE levels in the CNS could be significantly increased by consuming an MGO- or AGE-rich diet. However, no increase in EAE scores was observed after the AGE- and MGO rich diets. In line with this finding, gene expression analysis of the spinal cord revealed no differences in gene expression of pro-inflammatory markers such as CD3, F4/80, TNF and IL-6. We expected that increased availability of AGEs would lead to RAGE activation with subsequent secretion of pro-inflammatory cytokines, resulting in more inflammation and thus increased EAE score. These results may suggest that AGEs do not contribute to the disease pathology. Another explanation may be the possibility of a ceiling effect, meaning that the mice have already high EAE scores which cannot be increased further by dietary AGE intake. This could be due to a high AGEs:RAGE ratio, suggesting that there was not enough RAGE available to be activated by these increased amount of dietary AGEs. Thus, although the significant increase of AGE levels in the CNS after dietary AGE intake, the disease progression cannot aggravate.

We did not find significant correlations between dietary AGE levels and EAE scores (data not shown). As postulated before, the lack of correlation between 
the presence of AGEs in MS and EAE and disability could be due to the intracellular accumulation of AGEs. However, it seems that the accumulation of dietary AGEs mainly results in extracellular AGE deposits, which might be taken up by cells after accumulation in the CNS [43]. This may imply that increased amounts of dietary AGEs in the CNS are unable to increase disease severity and that the formation of AGEs during in EAE is a bystander effect of the disease instead of a contributor to the disease. However, we cannot exclude the possibility that AGEs have a minor effect on disease progression, which could be too low to measure during EAE. In addition, the intake of dietary AGEs was short which is a limitation of this study. Long-term dietary AGE intake could have a bigger effect compared to the short-term effect. Moreover, it should be noted that the EAE model is a severe inflammatory model. Therefore, the increase in inflammation possible due to AGEs and its effect on EAE score could be minimal and lost in the pool of EAE-induced inflammation itself. However, this does not rule out that there is a possible role for AGEs in EAE and MS during phases of the disease with less inflammation and with prolonged AGE intake.

\section{Glyoxalase-1 in MS and EAE}

To prevent the formation of AGEs, a-dicarbonyls MGO and GO are detoxified by the glyoxalase system. The system consist of two enzymes, glyoxalase 1 (Glo-1) and glyoxalase 2 (Glo-2), that together with glutathione (GSH) detoxify MGO into D-Lactate [58]. Using the methods previously described by McLellan et al. [59], we have determined Glo-1 activity in the protein lysates of post-mortem CNS tissue of MS patients and of the experimental animals.

We found that while Glo-1 activity was not altered in the MS lesions compared to the white matter of NDCs (chapter 2), Glo-1 activity is significantly decreased in the spinal cord and increased in the brain of EAE mice (chapter $\mathbf{3}$ ). Chapter 5 showed that dietary intake of MGO induces increased Glo-1 activity in the CNS. Moreover, we demonstrated that inflammatory activation of human primary astrocytes results in decreased Glo-1 activity (chapter 2). These data suggest that during a neuroinflammatory response Glo-1 activity is decreased. It has been shown that inflammatory cytokines such as TNF are able to decrease Glo-1 activity [7]. However, increasing the dietary levels of MGO induced Glo-1 activity, as previous published by Hansen et al. [60], probably as a defence mechanism to prevent the formation of AGEs. These data imply that inflammation is a strong trigger to modulate the Glo-1 activity by decreasing its activity compared to the auto-protective system. As a consequence, an inflammatory environment is able to decrease detoxification of MGO, thereby inducing the formation of AGEs.

\section{Clinical implications}

Our research has demonstrated that AGEs are formed in MS lesions and in the EAE model. However, no correlations with disease markers of MS were observed. Moreover, increasing the AGE load during EAE by means of a high 
AGE diet did not further drive disability or inflammation in EAE. These data indicate that $A G E s$ are formed during $M S$ and $E A E$ in an inflammatory environment but can be regarded as a bystander effect of the inflammation rather than a vast modulator of the progression of the disease. Moreover, we have also postulated that AGE accumulation might retrain intracellular. This will limit the potential of AGEs as biomarker. However, further studies need to be performed to determine whether astrocytes in vivo secrete AGEs during acute phases of inflammation and whether specific AGEs could be considered as a biomarker for the inflammatory status of the CNS.

\section{Lowering AGE levels as a therapeutic approach}

We have shown that increasing AGE levels in the CNS does not affect the course of EAE. On the other hand, by using pyridoxamine (PM) treatment and Glo-1 overexpressing mice, we were unable to lower AGE levels during $E A E$ as described in chapter 3. Due to the lack of AGE level modification in the CNS, we were unable to investigate the effects of lowered AGE levels on $E A E$ development. PM is one of the three natural forms of vitamin B6 and can lower AGEs by scavenging dicarbonyls such as MGO, thereby preventing the formation of AGEs [61]. Although we have previously shown that PM is able to reduce inflammation in vivo [62], in this current study, we found that PM, even using a 5 times higher dose, is not capable to affect AGE levels and subsequently inflammation during EAE. There are explanations for the fact that PM treatment did not influence AGE levels. First, it may be due to the severity of the animal model of MS. The EAE model is a severe inflammatory model which induces increased levels of AGEs in the CNS (chapter 3 ) and could therefore, because of its severity, limit the effect of PM and subsequently AGE reduction. Second, it is also still uncertain if oral administered PM will reach the CNS. Therefore, it would be of great importance to measure PM levels in the CNS to gain insight in PM distribution. It could be suggested that PM is unable to reach the CNS because of the conversion of PM to pyridoxal-5'-phosphate in the intestine and the liver $[63,64]$. Since only PM is able to reduce AGE levels, the conversion to pyridoxal-5'-phosphate could limit the effect of PM on AGE levels. Finally, PM could be cleared from the plasma by the kidneys, resulting in high urinary PM levels but therefore fail to reduce the AGE load. Therefore, it could be suggested that, in the EAE model, PM is not a potent AGE inhibitor. In addition to PM, we have used Glo-1 overexpressing mice aiming to reduce AGE levels during EAE. However, this approach was also unable to decrease in vivo AGE levels. Glo-1 is the key detoxification enzyme of the glyoxalase system which needs GSH to convert MGO into S-Lactoylglutathione. However, it has been described that the levels of GSH are decreased during $\operatorname{EAE}[65,66]$. This decrease in GSH availability most likely limits the detoxification of $M G O$ in the $E A E$ model, interfering with the reduction in AGE levels. The lack of success of these AGElowering approaches does not automatically mean that possible AGE lowering therapies are not affective for MS patients. Not all pathological mechanisms of MS are simulated in the EAE model. The MOG EAE model used in our 
experiments has a monophasic disease course, whereas most MS patients first experience relapses before entering a more progressive phase of the disease [67]. In addition, the monophasic disease course of EAE shows limited amounts of demyelinated regions in the CNS, whereas demyelination is clearly present in MS patients [68]. Therefore, we cannot exclude a possible beneficial effect of AGE lowering in MS patients. In addition to PM, there are other AGE lowering substances available which could have better results in AGE lowering in the EAE model and in MS patients. These compounds include aminoguanidine [69], alagebrium [70] and metformin [71], which are previously used in clinical trials investigating diabetes type 1, type 2 and cardiovascular diseases. However, one must be careful with the mechanism of action of these compounds because they are also known to have other effects such as reduction of nitric oxide synthase (aminoguanidine), inhibition of chopper-catalysed oxidation of ascorbic acid (alagebrium) and the reduction of plasma glucose levels (metformin) [58, 72]. This indicates that these substances may have beneficial effects on the disease progression, which may be independent of their potential AGE-lowering effects.

\section{Clinical recommendations}

The EAE model is a model characterized with high basal inflammation which can undermine the effect of AGEs, as can be seen in chapter $\mathbf{5}$ using the dietary AGEs during EAE. However, this does not exclude the possibility that AGEs are able to promote disease progression by contributing to low-grade inflammation. Although we did not observe an aggravating effect of dietary AGEs on the progression of EAE, our studies did reveal an accumulation of dietary AGEs in the CNS of healthy mice, which was accompanied by increased expression of pro-inflammatory cytokines (chapter 4). Therefore, it can be recommended to decrease dietary AGE intake for healthy individuals as well as MS patients. This is easily done by limiting the amount of toasting, grilling and frying of food or switch to alternative cooking methods such as pressure cookers or steamers to prevent the formation of AGEs in food [73]. In addition, one could opt to choose food that contains less AGEs, for example fresh fruit, vegetables, jam and white bread, compared to Twix, roasted pecan nuts, peanut butter and croissants [73]. One has to keep in mind that the difference in macro- and micronutrient intake might also affect health and wellbeing, despite of the AGE levels. The effects of a low dietary AGE diet can be easily investigated using the EAE model or by clinical trials in which MS patients remain on a low dietary AGE diet while their disease progression is determined over a period of time. Yet, the reduction in dietary AGE intake can also influence other diseases known to have increased AGE levels such as atherosclerosis and obesity. A low AGE diet will therefore be beneficial for not only MS patients, but also for patients with an inflammatory disease. In addition, this could also reduce the risk of MS patients for other inflammatory diseases. 


\section{Conclusion}

In conclusion, the induction of EAE leads to the formation of a-dicarbonyls and AGEs in the CNS. In line, we observed increased protein-bound MG-H1 levels in post-mortem samples of MS lesions compared to white matter of NDCs. However, AGE levels in the CSF did not positively correlate with disease markers of MS. The intake of dietary AGEs induced the accumulation of AGEs in the CNS of young healthy mice. This was accompanied by the induction of proinflammatory genes, indicating that dietary AGEs can influence the inflammatory state of the CNS. Although, when dietary AGEs were used to increase the AGEload in the CNS during EAE, the disease severity of the EAE model remained similar to control.

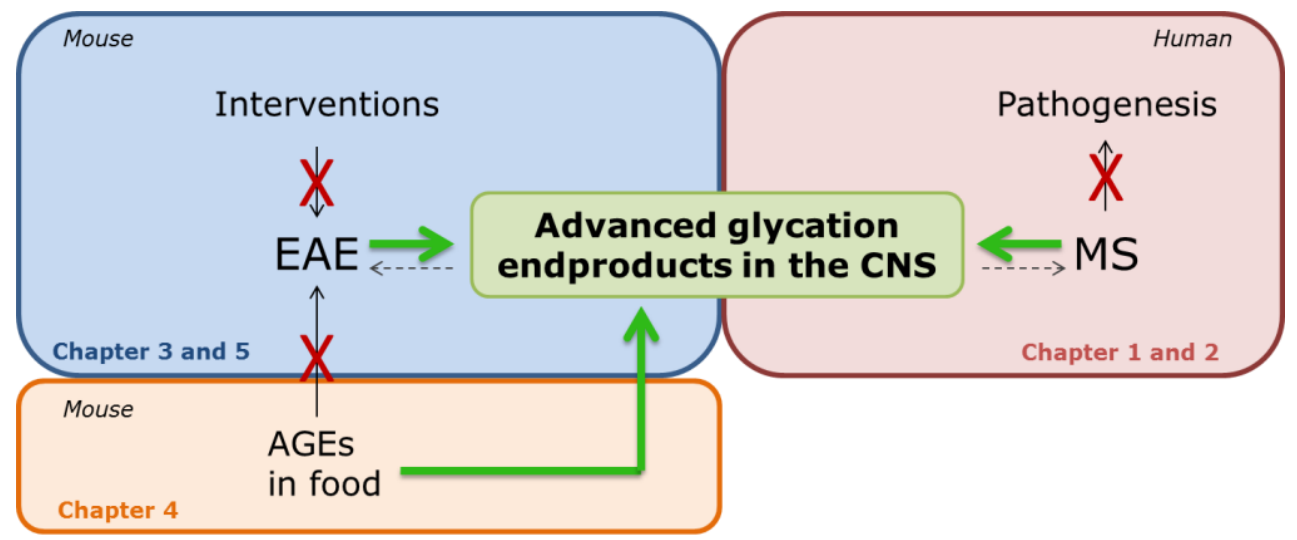

Figure 6.1. Overview of the results generated in this thesis. AGE levels were increased in the CNS of MS patients and in mice subjected to EAE (bold arrows). Partial correlation analysis did not reveal correlations between AGE levels in MS patients with disease parameters, reflecting pathogenesis (cross). Interventions, pyridoxamine and Glo1 overexpression mice, used in the EAE model to reduce AGE levels did not affect AGE levels and EAE outcome (cross). Whether AGEs are able to influence EAE or MS and could be targeted with other AGE-lowering compounds remains unknown (dashed arrows). Dietary AGEs were able to induce AGE levels in the CNS (bold arrow), but failed to aggravate disease progression of the EAE model (cross).

We believe that a-dicarbonyls and AGEs are probably formed during MS in the inflammatory phase of the disease but in the light of this current study, it is difficult to attribute disease progressing characteristic to AGEs, thereby also limiting its potential as a therapeutic target. However, experimental animal models can only be used to some extent and are not able to reflect all the aspects of MS. Therefore, we believe that further research needs to focus on MS patients. These patients have possible long-term AGE accumulation in the CNS, both due to the disease but also due to dietary intake which could affect disease progression different compared to the short-term experiment performed in 
animal models. Clinical studies investigating the dietary intake of MS patients by food frequency questionnaires, monitoring plasma a-dicarbonyl and AGE levels and the disease progression (e.g. EDSS and number of relapses) could contribute to understand the role of AGEs on MS progression. As we have confirmed that AGEs are produced in MS patients under inflammatory conditions, further research needs to be conducted to investigate the role of AGEs in MS patients. 


\section{References}

1. Browne, P., et al., Atlas of Multiple Sclerosis 2013: A growing global problem with widespread inequity. Neurology, 2014. 83(11): p. 1022-4.

2. Ellwardt, E. and F. Zipp, Molecular mechanisms linking neuroinflammation and neurodegeneration in MS. Exp Neurol, 2014. 262 Pt A: p. 8-17.

3. Ahmed, N., et al., Protein glycation, oxidation and nitration adduct residues and free adducts of cerebrospinal fluid in Alzheimer's disease and link to cognitive impairment. J Neurochem, 2005. 92(2): p. 255-63.

4. Dalfo, E., et al., Evidence of oxidative stress in the neocortex in incidental Lewy body disease. J Neuropathol Exp Neurol, 2005. 64(9): p. 816-30.

5. Gaens, K.H., et al., Nepsilon-(carboxymethyl)lysine-receptor for advanced glycation end product axis is a key modulator of obesity-induced dysregulation of adipokine expression and insulin resistance. Arterioscler Thromb Vasc Biol, 2014. 34(6): p. 1199-208.

6. Gaens, K.H., et al., Endogenous formation of Nepsilon-(carboxymethyl)lysine is increased in fatty livers and induces inflammatory markers in an in vitro model of hepatic steatosis. J Hepatol, 2012. 56(3): p. 647-55.

7. Hanssen, N.M., et al., Higher levels of advanced glycation endproducts in human carotid atherosclerotic plaques are associated with a rupture-prone phenotype. Eur Heart J, 2014. 35(17): p. 1137-46.

8. Sternberg, Z., et al., Diagnostic potential of plasma carboxymethyllysine and carboxyethyllysine in multiple sclerosis. J Neuroinflammation, 2010. 7: p. 72.

9. Sternberg, Z., et al., AGE-RAGE in multiple sclerosis brain. Immunol Invest, 2011. 40(2): p. 197-205.

10. Stitt, A.W., et al., Advanced glycation end products (AGEs) co-localize with AGE receptors in the retinal vasculature of diabetic and of AGE-infused rats. Am J Pathol, 1997. 150(2): p. 523-31.

11. van Eupen, M.G., et al., The methylglyoxal-derived AGE tetrahydropyrimidine is increased in plasma of individuals with type 1 diabetes mellitus and in atherosclerotic lesions and is associated with sVCAM-1. Diabetologia, 2013. 56(8): p. 1845-55.

12. Bogie, J.F., P. Stinissen, and J.J. Hendriks, Macrophage subsets and microglia in multiple sclerosis. Acta Neuropathol, 2014. 128(2): p. 191-213.

13. Nair, A., T.J. Frederick, and S.D. Miller, Astrocytes in multiple sclerosis: a product of their environment. Cell Mol Life Sci, 2008. 65(17): p. 2702-20.

14. Itoh, Y., et al., Dichloroacetate effects on glucose and lactate oxidation by neurons and astroglia in vitro and on glucose utilization by brain in vivo. Proc Natl Acad Sci U S A, 2003. 100(8): p. 4879-84.

15. Kelly, B. and L.A. O'Neill, Metabolic reprogramming in macrophages and dendritic cells in innate immunity. Cell Res, 2015. 25(7): p. 771-84.

16. Orihuela, R., C.A. McPherson, and G.J. Harry, Microglial M1/M2 polarization and metabolic states. Br J Pharmacol, 2016. 173(4): p. 649-65.

17. Allaman, I., M. Belanger, and P.J. Magistretti, Methylglyoxal, the dark side of glycolysis. Frontiers in Neuroscience, 2015. 9.

18. Correale, J. and M.F. Farez, The Role of Astrocytes in Multiple Sclerosis Progression. Front Neurol, 2015. 6: p. 180.

19. Hostenbach, S., et al., Astrocyte loss and astrogliosis in neuroinflammatory disorders. Neurosci Lett, 2014. 565: p. 39-41.

20. Karnovsky, M.L., Metabolic basis of phagocytic activity. Physiol Rev, 1962. 42: p. 143-68.

21. Barateiro, A., et al., $S 100 B$ as a Potential Biomarker and Therapeutic Target in Multiple Sclerosis. Mol Neurobiol, 2016. 53(6): p. 3976-3991.

22. Baardman, J., et al., Metabolic-epigenetic crosstalk in macrophage activation. Epigenomics, 2015. 7(7): p. 1155-64.

23. Wang, B., et al., Glycolysis-dependent histone deacetylase 4 degradation regulates inflammatory cytokine production. Mol Biol Cell, 2014. 25(21): p. 33007. 
24. Jin, X., et al., Advanced Glycation End Products Enhance Macrophages Polarization into M1 Phenotype through Activating RAGE/NF-kappaB Pathway. Biomed Res Int, 2015. 2015: p. 732450.

25. Brownlee, M., Biochemistry and molecular cell biology of diabetic complications. Nature, 2001. 414(6865): p. 813-20.

26. di Penta, A., et al., Oxidative stress and proinflammatory cytokines contribute to demyelination and axonal damage in a cerebellar culture model of neuroinflammation. PLoS One, 2013. 8(2): p. e54722.

27. Adiele, R.C. and C.A. Adiele, Metabolic defects in multiple sclerosis. Mitochondrion, 2017.

28. Wang, P., et al., Oxidative stress induced by lipid peroxidation is related with inflammation of demyelination and neurodegeneration in multiple sclerosis. Eur Neurol, 2014. 72(3-4): p. 249-54.

29. Procaccini, C., et al., Animal models of Multiple Sclerosis. Eur J Pharmacol, 2015. 759: p. 182-91.

30. Baker, D. and S. Amor, Experimental autoimmune encephalomyelitis is a good model of multiple sclerosis if used wisely. Mult Scler Relat Disord, 2014. 3(5): p. 555-64.

31. Kislinger, T., et al., N(epsilon)-(carboxymethyl)lysine adducts of proteins are ligands for receptor for advanced glycation end products that activate cell signaling pathways and modulate gene expression. J Biol Chem, 1999. 274(44): p. 31740-9.

32. Xue, J., et al., Advanced glycation end product recognition by the receptor for AGEs. Structure, 2011. 19(5): p. 722-32.

33. Xue, J., et al., The receptor for advanced glycation end products (RAGE) specifically recognizes methylglyoxal-derived AGEs. Biochemistry, 2014. 53(20): p. 3327-35.

34. Compston, A. and A. Coles, Multiple sclerosis. Lancet, 2008. 372(9648): p. 150217.

35. Pardridge, W.M., CSF, blood-brain barrier, and brain drug delivery. Expert Opin Drug Deliv, 2016. 13(7): p. 963-75.

36. Sternberg, Z., et al., Reduced expression of membrane-bound (m)RAGE is a biomarker of multiple sclerosis disease progression. Immunobiology, 2016. 221(2): p. 193-8.

37. Yan, S.S., et al., Suppression of experimental autoimmune encephalomyelitis by selective blockade of encephalitogenic $T$-cell infiltration of the central nervous system. Nat Med, 2003. 9(3): p. 287-93.

38. Sternberg, Z., et al., Soluble receptor for advanced glycation end products in multiple sclerosis: a potential marker of disease severity. Multiple sclerosis, 2008. 14(6): p. 759-63.

39. Galichet, A., M. Weibel, and C.W. Heizmann, Calcium-regulated intramembrane proteolysis of the RAGE receptor. Biochem Biophys Res Commun, 2008. 370(1): p. $1-5$.

40. Raucci, A., et al., A soluble form of the receptor for advanced glycation endproducts (RAGE) is produced by proteolytic cleavage of the membrane-bound form by the sheddase a disintegrin and metalloprotease 10 (ADAM10). FASEB J, 2008. 22(10): p. 3716-27.

41. Yamakawa, N., et al., Proteolytic release of the receptor for advanced glycation end products from in vitro and in situ alveolar epithelial cells. Am J Physiol Lung Cell Mol Physiol, 2011. 300(4): p. L516-25.

42. Zhang, L., et al., Receptor for advanced glycation end products is subjected to protein ectodomain shedding by metalloproteinases. J Biol Chem, 2008. 283(51): p. 35507-16.

43. Cai, W., et al., Oral glycotoxins are a modifiable cause of dementia and the metabolic syndrome in mice and humans. Proc Natl Acad Sci U S A, 2014. 111(13): p. 4940-5.

44. Vlassara, H. and G.E. Striker, AGE restriction in diabetes mellitus: a paradigm shift. Nat Rev Endocrinol, 2011. 7(9): p. 526-39. 
45. Gaens, K.H.J., et al., N-epsilon-(Carboxymethyl) lysine-Receptor for Advanced Glycation End Product Axis Is a Key Modulator of Obesity-Induced Dysregulation of Adipokine Expression and Insulin Resistance. Arteriosclerosis Thrombosis and Vascular Biology, 2014. 34(6): p. 1199-1208.

46. Wetzels, S., et al., Advanced Glycation Endproducts Are Increased in the Animal Model of Multiple Sclerosis but Cannot Be Reduced by Pyridoxamine Treatment or Glyoxalase 1 Overexpression. Int J Mol Sci, 2018. 19(5).

47. Rawji, K.S. and V.W. Yong, The benefits and detriments of macrophages/microglia in models of multiple sclerosis. Clin Dev Immunol, 2013. 2013: p. 948976.

48. Dhananjayan, K., et al., Activation of Macrophages and Microglia by Interferongamma and Lipopolysaccharide Increases Methylglyoxal Production: A New Mechanism in the Development of Vascular Complications and Cognitive Decline in Type 2 Diabetes Mellitus? J Alzheimers Dis, 2017. 59(2): p. 467-479.

49. Wang, Z., et al., Activation of astrocytes by advanced glycation end products: cytokines induction and nitric oxide release. Acta Pharmacol Sin, 2002. 23(11): p. 974-80.

50. Maillaird, L., Action des acides aminés sur les sucres: formation des mélanoidines paar voie méthodique. CR Acad Sci, 1912. 154: p. 66-68.

51. Poulsen, M.W., et al., Advanced glycation endproducts in food and their effects on health. Food Chem Toxicol, 2013. 60: p. 10-37.

52. N, A.L. and F. Carbonero, Impact of Maillard reaction products on nutrition and health: Current knowledge and need to understand their fate in the human digestive system. Crit Rev Food Sci Nutr, 2017: p. 1-14.

53. Scheijen J.L.J.M, H.N.M.J., van Greevenbroek M.M., Van der Kallen C.J., Feskens E.J.M., Stehouwer C.D.A., Schalkwijk C.G. , Dietary intake of advanced glycation endproducts is associated with higher levels of advanced glycation endproducts in plasma and urine: The CODAM study. Clinical Nutrition 2017.

54. Cai, W., et al., Oral advanced glycation endproducts (AGES) promote insulin resistance and diabetes by depleting the antioxidant defenses AGE receptor-1 and sirtuin 1. Proc Natl Acad Sci U S A, 2012. 109(39): p. 15888-93.

55. Mahad, D.J. and R.M. Ransohoff, The role of MCP-1 (CCL2) and CCR2 in multiple sclerosis and experimental autoimmune encephalomyelitis (EAE). Semin Immunol, 2003. 15(1): p. 23-32.

56. Brod, S.A. and V.L. Bauer, Ingested (oral) tocilizumab inhibits EAE. Cytokine, 2014. 68(2): p. 86-93.

57. Liliensiek, B., et al., Receptor for advanced glycation end products (RAGE) regulates sepsis but not the adaptive immune response. J Clin Invest, 2004. 113(11): p. $1641-50$.

58. Maessen, D.E., C.D. Stehouwer, and C.G. Schalkwijk, The role of methylglyoxal and the glyoxalase system in diabetes and other age-related diseases. Clin Sci (Lond), 2015. 128(12): p. 839-61.

59. McLellan, A.C., S.A. Phillips, and P.J. Thornalley, The assay of $S-D-$ lactoylglutathione in biological systems. Anal Biochem, 1993. 211(1): p. 37-43.

60. Hansen, F., et al., Methylglyoxal Induces Changes in the Glyoxalase System and Impairs Glutamate Uptake Activity in Primary Astrocytes. Oxid Med Cell Longev, 2017. 2017: p. 9574201.

61. Voziyan, P.A. and B.G. Hudson, Pyridoxamine as a multifunctional pharmaceutical: targeting pathogenic glycation and oxidative damage. Cell Mol Life Sci, 2005. 62(15): p. 1671-81.

62. Maessen, D.E., et al., Delayed Intervention With Pyridoxamine Improves Metabolic Function and Prevents Adipose Tissue Inflammation and Insulin Resistance in High-Fat Diet-Induced Obese Mice. Diabetes, 2016. 65(4): p. 95666.

63. Sakurai, T., et al., Absorption and metabolism of pyridoxamine in mice. I. Pyridoxal as the only form of transport in blood. J Nutr Sci Vitaminol (Tokyo), 1991. 37(4): p. 341-8. 
64. Sakurai, T., et al., Absorption and metabolism of pyridoxamine in mice. II. Transformation of pyridoxamine to pyridoxal in intestinal tissues. J Nutr Sci Vitaminol (Tokyo), 1992. 38(3): p. 227-33.

65. Dasgupta, A., et al., Increased carbonylation, protein aggregation and apoptosis in the spinal cord of mice with experimental autoimmune encephalomyelitis. ASN Neuro, 2013. 5(1): p. e00111.

66. Zheng, J. and O.A. Bizzozero, Accumulation of protein carbonyls within cerebellar astrocytes in murine experimental autoimmune encephalomyelitis. J Neurosci Res, 2010. 88(15): p. 3376-85.

67. Sriram, S. and I. Steiner, Experimental allergic encephalomyelitis: a misleading model of multiple sclerosis. Ann Neurol, 2005. 58(6): p. 939-45.

68. Baker, D., et al., Induction of chronic relapsing experimental allergic encephalomyelitis in Biozzi mice. J Neuroimmunol, 1990. 28(3): p. 261-70.

69. Brownlee, M., et al., Aminoguanidine prevents diabetes-induced arterial wall protein cross-linking. Science, 1986. 232(4758): p. 1629-32.

70. Sell, D.R. and V.M. Monnier, Molecular basis of arterial stiffening: role of glycation - a mini-review. Gerontology, 2012. 58(3): p. 227-37.

71. Ruggiero-Lopez, D., et al., Reaction of metformin with dicarbonyl compounds. Possible implication in the inhibition of advanced glycation end product formation. Biochem Pharmacol, 1999. 58(11): p. 1765-73.

72. Borg, D.J. and J.M. Forbes, Targeting advanced glycation with pharmaceutical agents: where are we now? Glycoconj J, 2016. 33(4): p. 653-70.

73. Scheijen, J., et al., Analysis of advanced glycation endproducts in selected food items by ultra-performance liquid chromatography tandem mass spectrometry: Presentation of a dietary AGE database. Food Chem, 2016. 190: p. 1145-1150. 



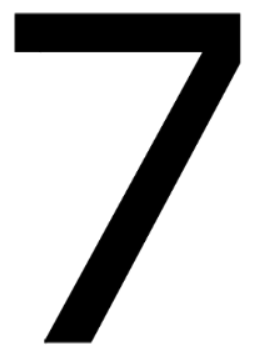

Nederlandse samenvatting 


\section{Samenvatting}

Multiple sclerose (MS) is een auto-immuun ziekte die het centraal zenuwstelsel (CZS) aantast. Tijdens MS zorgt de activatie van zowel het aangeboren als het verworven immuunsysteem voor demyelinisatie, waarbij de myelineschede rond de axonen wordt aangetast. Geschat wordt dat er 2.5 miljoen mensen wereldwijd lijden aan MS. Deze patiënten hebben uiteenlopende symptomen die variëren van tintelingen, krachtverlies, problemen met het gezichtsvermogen en spraakstoornissen. De symptomen zijn afhankelijk van het gebied in het CZS dat door demyelinisatie is aangetast. De exacte oorzaak van MS is nog onbekend. Men gaat ervan uit dat de ziekte een samenspel is van genetische factoren en omgevingsfactoren. Tot op heden is er geen geneesmiddel voor MS. MSpatiënten zijn daarom toegewezen op zogenaamde ziekte modificerende therapieën die de inflammatoire component van de ziekte verlaagd en hierdoor verlichting geeft van de symptomen. In dit proefschrift hebben wij onderzocht of "advanced glycation endproducts" (AGEs) een rol spelen in het ziekteproces van MS. De belangrijkste bevindingen van het onderzoek worden in dit hoofdstuk samengevat en bediscussieerd.

\section{In vivo vorming van AGEs}

MS wordt gekarakteriseerd door de infiltratie van immuuncellen in het CZS. Wanneer autoreactieve T-cellen eenmaal in het CZS zijn geïnfiltreerd, worden ze gereactiveerd door myeline fagocyterende macrofagen en microglia. Daarnaast zorgt de activatie van astrocyten voor de productie van pro-inflammatoire cytokines en chemokines. Dit draagt bij aan de ontstekingsreactie in het CZS en de degeneratie van zenuwcellen. De activatie van macrofagen, microglia en astrocyten zorgt voor een cellulaire switch in metabolisme, waarbij glycolyse wordt geïnduceerd. Dit kan zorgen voor de productie van glycolyse-bijproducten zoals methylglyoxaal (MGO) en glyoxaal (GO), ook wel a-dicarbonyls genoemd. Zowel MGO als GO kan aminozuren modificeren waardoor AGEs ontstaan zoals CML, CEL en MG-H1. Wanneer deze AGEs binden aan de receptor voor AGEs (RAGE) induceren ze de productie van pro-inflammatoire cytokines. Dit kan uiteindelijk bijdragen aan de inflammatoire omgeving van het CZS.

\section{In vivo vorming van AGEs in MS-patiënten}

In hoofdstuk 2 hebben we onderzocht of AGEs verhoogd aanwezig zijn in MS laesies ten opzichte van hersenweefsel afkomstig van niet-dementerende controles (NDCs). We vonden dat eiwitgebonden MG-H1 significant was verhoogd in MS laesies, terwijl CML en CEL onveranderd waren. Tevens hebben we uitgesloten dat post-mortem delay (PMD), de tijd tussen het overlijden van de MS-patiënt en het verzamelen van het weefsel, een bijdrage levert aan verhoogde AGE niveaus.

Door middel van fluorescente dubbelkleuringen, hebben we in hoofdstuk 2 laten zien dat astrocyten de belangrijkste bijdrage leveren aan de accumulatie van MG-H1 in MS laesies. RAGE was aanwezig op macrofagen en microglia, 
maar niet op astrocyten. Hierdoor kan er een paracriene werking optreden van astrocyte-geproduceerde AGEs op RAGE-positieve macrofagen en microglia. RAGE activatie kan op meerdere manieren bijdragen aan de inflammatie. Dit kan enerzijds door de activatie van de nucleaire transcriptiefactor NF-kB en de productie van pro-inflammatoire cytokines. Anderzijds zorgt RAGE activatie voor oxidatieve stress, dat direct kan bijdragen aan demyelinisatie. We kunnen echter niet uitsluiten dat de vorming van AGEs een gevolg is van de inflammatoire processen in het CZS van MS-patiënten, zonder dat het een effect heeft op de neuroinflammatie.

\section{In vivo vorming van AGEs in het EAE model}

In hoofdstuk 3 hebben we onderzocht of AGEs ook opstapelen in een diermodel voor MS, het experimentele auto-immuun encefalomyelitis (EAE) model. In dit model wordt de immuunrespons van MS-patiënten nagebootst. Dit zorgt voor een infiltratie van $\mathrm{CD}^{+}{ }^{+}$en $\mathrm{CD}^{+}{ }^{+} \mathrm{T}$-cellen, B-cellen en monocyten in het CZS en de inductie van myeline afbraak. In tegenstelling tot de humane data vonden we in het EAE model een verhoging van ongebonden CML, CEL en MG-H1 in het ruggenmerg, terwijl de eiwitgebonden AGEs onveranderd bleven. Waarom eiwitgebonden MG-H1 verhoogd is in humane MS laesies en vrije AGEs in het ruggenmerg van EAE muizen blijft onbeantwoord. Het is mogelijk dat de afbraak van eiwitgebonden AGEs bijdraagt aan de niveaus van ongebonden AGEs.

Onze resultaten laten zien dat, in zowel humane MS laesies als in het diermodel van MS, AGEs verhoogd zijn. Daarom hebben we in hoofdstuk 3 onderzocht wat het effect is van het verlagen van AGE niveaus tijdens EAE. Er werden twee interventies uitgevoerd om de AGEs te verlagen. Als eerste interventie hebben we de muizen twee maal daags behandeld met pyridoxamine. Pyridoxamine is een vitamine B6 variant en kan AGEs verlagen door het wegvangen van de precursor MGO. Orale toediening van pyridoxamine tijdens de EAE liet geen effect zien op het ziekteverloop. Daarbij kon pyridoxamine toediening niet zorgen voor een verlaging van de AGE levels in het CZS van de muizen. Als tweede interventie hebben we gebruik gemaakt van de Glo-1 transgene muizen. Deze muizen hebben een overexpressie van het humane enzym glyoxalase 1 (Glo-1). Glo-1 is betrokken bij de afbraak van MGO en kan dus zorgen voor lage AGE levels. Het gebruik van Glo-1 transgene muizen liet geen verschil zien op het ziekteverloop van EAE. Ook met deze interventie konden we de AGE niveaus niet verlagen. Omdat beide benaderingen om AGEs te reduceren geen verlaging van de AGE niveaus in het CZS induceerden, kunnen we geen uitspraak doen over het mogelijk effect van AGE verlaging op het ziekteverloop van EAE.

\section{AGEs als een potentiële marker van ziekte progressie}

Om te bepalen of AGEs gebuikt kunnen worden als potentiele biomerker voor de progressie van MS, hebben we in hoofdstuk 2 onderzocht of er een correlatie aanwezig is tussen a-dicarbonyl en AGE niveaus in het plasma en hersenvocht (CSF) van MS-patiënten. Hiervoor hebben we gebruik gemaakt van plasma en 
CSF monsters van dezelfde patiënten. Correlatie analyses toonden aan dat adicarbonyl en vrije AGE niveaus in het plasma correleren met hun respectievelijke waarden in het CSF. De eiwitgebonden AGEs bleken niet te correleren tussen het plasma en het CSF.

Verder hebben we onderzocht of a-dicarbonyl en AGE niveaus in het CSF correleren met indicatoren voor MS ziekte progressie zoals de "expended disability status scale" (EDSS), het aantal "relapses", oftewel aanvallen van het immuun systeem op de myeline in het CZS, en de ziekteduur. Onze resultaten toonden aan dat er geen positieve correlaties waren tussen a-dicarbonyl en AGE niveaus in het CSF met de drie bovengenoemde indicatoren voor ziekte progressie. Daarbij vonden we ook geen correlatie tussen AGE niveaus en EAE ziektes scores. We kunnen hieruit concluderen dat AGEs niet gebruikt kunnen worden als merker voor ziekte progressie.

\section{Inflammatie geïnduceerde AGE vorming}

Het gebrek aan correlatie tussen AGE niveaus en ziekte progressie (zowel in de humane weefsels als in het diermodel) lijkt aan te duiden dat AGE accumulatie een bijeffect is van de inflammatie in het CZS. In het addendum van hoofdstuk 3 hebben we onderzocht of demyelinisatie op zichzelf ook kan zorgen voor een verhoging van AGE niveaus in het CZS, zonder perifere inflammatoire reacties. Demyelinisatie wordt geïnduceerd door cuprizone toe te voegen aan het voer van muizen. Dit leidt tot apoptose van oligodendrocyten, waardoor demyelinisatie optreedt. In het cuprizone model werden geen significante verhoogde a-dicarbonyl en AGE niveaus vast gesteld. Het lijkt er dus op dat demyelinisatie op zichzelf niet kan zorgen voor verhoogde AGE niveaus. Ondanks dat de verhoogde a-dicarbonyl en AGE niveaus in MS laesies en in het EAE model niet correleren met de ernst van de ziekte, kunnen we concluderen dat de inflammatoire omgeving van het CZS leidt tot productie van adicarbonyls en AGEs.

\section{AGEs uit de voeding}

De vorming van AGEs vindt ook plaats tijdens het bereiden van voedsel, een proces dat de Maillard-reactie heet. Deze reactie wordt versneld wanneer er voedsel met hoge hitte wordt bereid. AGEs in de voeding dragen bij aan de smaak en aroma van voedsel en komen veel voor in het Westerse dieet dat grotendeels bestaat uit gefrituurd, gegrild en gebakken voedsel.

In hoofdstuk 4 hebben we onderzocht of AGEs uit de voeding kunnen opstapelen in het CZS van gezonde jonge muizen. Onze data laten zien dat verhoogde inname van MGO en AGEs zorgen voor accumulatie van vrij CEL en MG-H1 in zowel het plasma als het CZS van deze gezonde muizen. Deze resultaten impliceren dat vrije AGEs, opgenomen vanuit de voeding, over de bloed-hersen barrière getransporteerd worden en accumuleren in het CZS. Bovendien is de genexpressie van pro-inflammatoire genen verhoogd in het CZS 
van muizen bij een hoge MGO en AGE inname. Het lijkt er daarom op dat AGEs uit de voeding kunnen bijdragen aan de inflammatoire status van het CZS, zelfs in gezonde individuen.

\section{Voedings-AGEs als modulator van het EAE model?}

Omdat een hoge inname van MGO en AGEs zorgt voor opstapeling van AGEs in het CZS en kan bijdragen aan verhoogde genexpressie van pro-inflammatoire genen, hebben we de hypothese gesteld dat de toename van AGEs tijdens de EAE zorgt voor een verergering van het ziekteverloop. In hoofdstuk $\mathbf{5}$ hebben we het effect van AGEs uit de voeding op het EAE verloop onderzocht. We vonden dat, bovenop de accumulatie van AGEs uitsluitend door EAE, de AGE niveaus nog verder verhoogd waren door een hoog AGE dieet. Desondanks werd er geen effect waargenomen op ziekteverloop en daarbij ook geen verandering in de genexpressie van pro-inflammatoire genen.

\section{Glyoxalase-1 in MS en EAE}

Om de vorming van AGEs tegen te gaan, worden a-dicarbonyls MGO en GO gedetoxificeerd door het glyoxalase systeem. Dit systeem bestaat uit twee enzymen: glyoxalase-1 (Glo-1) en glyoxalase-2 (Glo-2), die samen met gereduceerd glutathion (GSH) zorgen voor een detoxificatie tot D-lactaat. Hierbij is Glo-1 het belangrijkste enzym aangezien de omzetting van MGO door Glo-1 de snelheidsbeperkende stap is.

In hoofdstuk 2 hebben we laten zien dat de Glo-1 activiteit niet veranderd is tussen MS laesies en de witte stof van NDCs. In het EAE model is de Glo-1 activiteit verlaagd in het ruggenmerg (hoofdstuk 3). Daarbij hebben we laten zien dat de inflammatoire activatie van primaire humane astrocyten zorgt voor een verlaging van Glo-1 activiteit (hoofdstuk 2). Deze resultaten impliceren dat tijdens inflammatie de activiteit van Glo-1 afneemt. Als gevolg hiervan kan een inflammatoire omgeving de detoxificatie van MGO verminderen, waardoor de vorming van AGEs wordt geïnduceerd. Inname van MGO uit de voeding zorgt mogelijk voor een verhoging van de Glo-1 activiteit in het CZS als beschermingsmechanisme om de vorming van AGEs te onderdrukken.

\section{Conclusie}

Samenvattend leidt de inductie van EAE tot de vorming van a-dicarbonyls en AGEs in het CZS. We vonden verhoogde eiwit-gebonden MG-H1-niveaus in postmortem-materialen van MS-laesies. We vonden echter geen positieve correlaties tussen AGE niveaus in het CSF en de ernst van MS. Deze resultaten tonen aan dat AGEs waarschijnlijk geen significant bijdragen hebben aan de progressie van de ziekte. Dit beperkt de therapeutische toepassing voor MS-patiënten. Experimentele diermodellen zijn echter niet in staat om alle aspecten van MS na te bootsen en daarom zal verder onderzoek uitgevoerd moet worden op MSpatiënten. Deze patiënten hebben mogelijk een langdurige AGE-accumulatie in 
het CZS, zowel als gevolg van de ziekte, maar ook als gevolg van een inname via de voeding die de ziekteprogressie anders zou kunnen beïnvloeden. Klinische studies die de voedingsinname van MS-patiënten onderzoeken aan de hand van voedselfrequentievragenlijsten, het volgen van de plasma a-dicarbonyl- en AGEniveaus en de ziekteprogressie (bijvoorbeeld EDSS en het aantal recidieven) kunnen bijdragen aan een beter inzicht in de rol van AGEs bij MS-progressie. We hebben bevestigd dat er bij MS-patiënten onder inflammatoire condities AGEs worden geproduceerd, echter zal verder onderzocht moeten worden wat de exacte rol hiervan is bij MS-patiënten. 


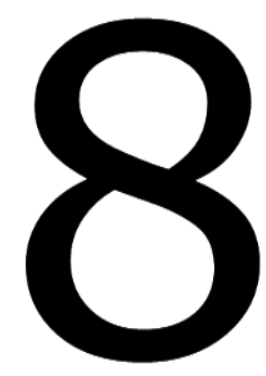

Valorisation 


\section{Valorisation}

Multiple sclerosis (MS) is the main cause of disability in young adults [1]. According to the National MS Society, it is estimated that 2.3 million individuals worldwide are diagnosed with MS [2]. Over the years, the incidence of MS has been increasing in the Netherlands, from 4/100.000 in 1996-2004 to 9/100.000 in 2007/2008 [3]. To this date, the prevalence of MS in the Netherlands is estimated to be $100 / 100.000$ [4]. In Belgium, there are no recent studies examining the prevalence of MS. However, it was documented to be $87.9 / 100.00$ in 1994 [5], which is similar to the prevalence in the Netherlands. These results indicate that 17.000 individuals in the Netherlands and 13.500 individuals in Belgium [6], are diagnosed with MS. MS patients experience a variety of symptoms which affect their daily life. As the disease progresses, the symptoms worsen, leading to an increase in disability and a reduction in mobility of MS patients [7]. A survey conducted with 200 MS patients from Spain, Germany, Norway and Italy revealed that $86 \%$ of the MS patients was unable to maintain the same level of study/work as before the diagnosis [7]. In addition to work and study, their disease also impacted their social life. Besides the impact of MS on the quality of life, the socio-economic burden of MS is also significant. Uitdehaag et al. investigated the annual health care costs per MS patient in the Netherlands. These costs include inpatient care, consultations, medication and disease modifying therapies (DMTs) but also costs related to service and informal care costs [4]. For patients with a mild disease (EDSS 0-3), the mean annual health care costs are $€ 10.626$, with increasing costs reaching $€ 30.716$ as the disease worsens to EDSS 7-9 [4]. Moreover, they showed that with increasing EDSS, the indirect costs such as short-term and long-term absence, invalidity and early retirement also increase, resulting in a total annual cost of $€ 50.500$. Apart from the annual costs of health care and medication, MS patients are also more vulnerable for additional health treats. Research has shown that MS patients have a higher risk of infection, which are even associated with relapses [8]. Wijnands et al. revealed that MS patients are twice as likely to be hospitalized due to infections such as pneumonia, urinary system infections, intestinal infections and skin infections compared to people without MS [9]. This also contributes to high health care costs.

Although a lot of research has been performed in the last decades, the cause of MS remains to be identified. Subsequently, this means that there is no cure for the disease yet. Current therapies only aim to reduce the inflammatory component of the disease. These DMTs are therefore prescribed to patients with relapsing-remitting $\mathrm{MS}$ and are less functional for secondary progressive MS patients. The drawback of these therapies are the side effects such as nausea, headache, increased risk of infections and diarrhoea depending on the therapy [10].

Our research has focussed on the role of advanced glycation endproducts (AGEs) in MS. AGEs were previously described to be increased in inflammatory diseases 
[11-14], which could potentially contribute to the disease or their complications. The aim of our study was to elucidate whether AGEs are formed in the CNS during the development of MS and their potential effects on disease pathology. This fundamental research was performed using human post-mortem specimens from MS lesions and a mouse model for MS, the experimental autoimmune encephalomyelitis (EAE) model. Moreover, we aimed to target AGEs in the EAE model to determine their therapeutic value.

\section{Valorisation of the key findings of this thesis}

This thesis revealed that MGO-derived MG-H1 is increased in post-mortem lesions of MS patients. Moreover, we discovered that AGEs accumulate in the CNS of mice subjected to EAE. Although we were unable to reduce AGE levels with generally accepted AGE lowering strategies in the animal model of MS, we believe that further research is needed to investigate the therapeutic potential of AGE lowering in MS patients. If proven to be beneficial, AGE lowering therapies could be considered as an add-on treatment, improving the quality of life for MS patients.

First, we evaluated the potential of AGE levels in the cerebrospinal fluid (CSF) as a biomarker for disease progression of MS. AGE levels in the CSF were determined and correlated to markers for disease progression such as number of relapses, EDSS and disease duration. These analyses were performed to determine whether AGE levels in the CSF could be used as a biomarker for MS disease progression. Our human data revealed that we could not detect positive correlations between AGE levels in the CSF and markers for disease progression. There may be several reasons why we could not identify a clear link between CSF AGE levels and disease severity. Use of anti-inflammatory drugs, common treatments for MS, at the time that sample were collected could directly impact the AGE formation in the CNS. Moreover, whether or not patients are experiencing a relapse during sample collection can also influence the AGE levels in the CSF. Since we are not aware whether these patients experienced a relapse, it is difficult to discover the exact link between AGE levels in the CSF and disease progression in MS. The potential to use AGE levels in the CSF as a biomarker for MS should be investigated further in detail, for example include patients with and without anti-inflammatory drug use and collect samples of the same patient during a relapse and in the remitting phase following that relapse. Moreover, as we have revealed that free AGE and a-dicarbonyl levels in the CSF correlate with their respective levels in the CSF, it should be investigated whether plasma AGE levels could be used as a biomarker for disease progression. Blood is obtained more easily and with less discomfort for the MS patients compared to CSF. The potential use of AGE levels as a biomarker for disease progression will also increase the knowledge about AGE formation in MS patients, contributing to the realization of the therapeutic potential of AGE lowering in MS. However, one must take into account that levels of AGEs in the CSF or blood may not reflect the AGE levels in the brain parenchyma which 
could be important drivers of inflammation and thus disease progression. Taken all together, we were able to detect AGEs in CSF and plasma of MS patients, but their use as biomarkers for disease progression may be limited. Nonetheless, we cannot conclude whether or not AGEs play a role in the etiology of the disease and thus we cannot exclude the therapeutic potential of targeting AGEs in MS patients.

\section{Lifestyle interventions as a therapy for MS}

The increase in prevalence of MS, as mentioned above, is attributed to the revision of the diagnostic criteria and the possibility to diagnose patients after one clinical incident [15], which makes diagnosis more specific. However, a study on the prevalence and incidence of MS in Norway suggested that the change in lifestyle factors, such as decrease of vitamin D and fatty fish intake, could also contribute to the increase prevalence of MS [16]. Therefore, one could suggest that the dietary intake of AGEs could affect the prevalence of MS. Using young healthy mice, our study revealed that high intake of dietary AGEs for 5 weeks results in increased levels of AGEs in the CNS, which was accompanied by elevated expression patterns of pro-inflammatory cytokines. Therefore, lifelong accumulation of AGEs in the CNS of MS patients may contribute to the neuroinflammatory environment of the CNS. Our research suggests that dietary AGEs are degraded in the intestine into single amino acids and absorbed, leading to increased levels of free AGEs in the plasma. Moreover, we have shown that free AGEs are able to cross the blood-brain barrier, as we observed an accumulation of AGEs in the CNS. This together suggests that reducing the intake of dietary AGEs could be beneficial, for MS patients but also for healthy individuals or individuals who suffer from other inflammatory diseases. Preliminary data from our laboratory revealed that switching mice from a high AGE to a low AGE diet reduced the amount of free AGEs in the plasma drastically within one week. This data is promising and implies that diet could help prevent and reduce AGE accumulation in tissues such as the CNS.

First, it would be important to investigate whether an AGE-rich diet results in a worse disease progression or higher relapse rate. This can be easily monitored by food diaries. MS patients can keep track of what they eat and based on this information the dietary AGE intake can be determined. This can be done by using already available databases which contain the AGE content of commonly consumed food items [17]. This data will be used to analyse the correlations between dietary AGE intake and disease progression markers such as number of relapses and EDSS. If these results show an increased disease progression with AGE-rich diets, the next step would be to investigate whether a reduction in dietary AGE intake is beneficial for MS patients. To evaluate the effect of lowering dietary AGE intake on disease progression or EDSS, the study has to be performed over a long period of time in which patients will follow a personalized diet low in AGEs. To date it is still unknown how fast a low AGE diet is able to decrease AGE levels in the tissues. We are currently investigating in our 
laboratory whether a switch from high AGE to low AGE diet can reduce AGE levels in various tissues including the CNS. Based on our mouse data, it can be speculated that free plasma AGE levels are a reflection of dietary intake, which result in a fast decline in AGE levels since the intake is lower. However, in the tissue, the decrease of AGE levels is expected to be slower as this needs to be cleared from the tissue. The results of our current animal study in which animals fed a high AGE diet for 5 weeks and then switch to a low AGE diet for 5 weeks should give insight in the potential of dietary AGE restriction and their respective levels in tissue. These data can be used to translate into the human situation.

During the clinical dietary AGE restriction study, disease progression, number of relapses and/or wellbeing of MS patients should be monitored closely to detect any signs of relapses. Previous research has shown that supplementation of vitamin $D$, in patients with low plasma vitamin $D$ levels, in addition to natalizumab treatment, led to reduce rate of the annual relapses within one year [18]. This shows that with an additional therapy, differences in relapse rate can be achieved. In addition to the close monitoring of the disease progression, MS patients enrolled in the clinical trial are coached by dieticians. Personalized diets can be set up to decrease dietary AGE intake. This can be done by replacing high AGE content food such as croissants, biscuits, peanut butter and black pudding with food that is low in AGEs such as fresh vegetables, fruit, jam, milk and white bread [17]. A reduction in dietary AGE intake can also be achieved by changing cooking methods. It is known that cooking methods such as grilling, frying, baking and toasting increase the amount of AGEs in food [19]. Therefore, the stimulating alternative cooking methods such as steaming and poaching, and cooking on lower heat, will reduce the formation of AGEs during cooking [20]. This could be interesting for manufactures of steam ovens, high pressure cookers or airfryers.

When these trials reveal that a low AGE diet has a positive effect on MS disease progression and wellbeing of MS patients, it could be implemented for all MS patients, and even for patients with other (neuro)inflammatory diseases as an add-on therapy. Moreover, it could be speculated that lowering dietary AGE intake might be beneficial for all people to reduce the accumulation of AGEs in the body. It is expected that a change in lifestyle will have a low impact on MS patients as it concerns a switch in low AGE food products and other cooking methods which are not expected to give any side effects. Clinicians and dieticians should help the MS patients to adapt to their new life style.

\section{Potential AGE lowering therapeutics for MS}

Lowering of AGEs can also be done by therapeutics. In this thesis, we investigated the effect of pyridoxamine during EAE. Pyridoxamine is a natural vitamin B6 analogue that is known to scavenge MGO thereby preventing AGE formation [21]. Twice daily oral supplementation of pyridoxamine was unfortunately unable to reduce the disease score in the EAE model. However, 
examination of plasma and CNS of pyridoxamine treated mice revealed that pyridoxamine was unsuccessful at reducing AGE levels in the plasma and CNS. One explanation for the lack in AGE lowering in the EAE model could be the severity of the model. Pyridoxamine has been used previously in a small clinical trial $(n=10)$ to reduce pentosidine levels in $80 \%$ of schizophrenia patients [22]. It has been proven that 24 weeks of pyridoxamine supplementation is able to reduce AGE levels in clinical trials studying osteoarthritis and diabetic nephropathy $[23,24]$. Moreover, Maessen et al. have previously showed that pyridoxamine treatment in mice was able to inhibit adipose tissue inflammation during obesity, despite the absence of a strong reduction in AGE levels [25]. Therefore, we cannot exclude the possibility that pyridoxamine treatments might be beneficial for MS patients. To evaluate the disease progression of MS patients, the clinical study should be conducted over a long period of time to assess the disease progression of MS patients. To ensure that pyridoxamine enters the circulation without converting to its other isoform pyridoxal-5'phosphate [26, 27], pyridoxamine levels should be monitored in MS patients during the clinical trial. Whether pyridoxamine levels can be increased in vivo might limit the potential of pyridoxamine as a AGE lowering intervention. Therefore, other AGE lowering therapeutics should also be investigated.

Therapeutics such as aminoguanidine [28], alagebrium [29] and metformin [30], are previously used investigating diabetes type 1, type 2 and cardiovascular diseases. These substances are known to reduce AGEs, but when used in clinical trials, the AGE lowering potential of aminoguanidine and alagebrium was not examined [28, 31]. Metformin, a known therapeutic for diabetes, was able to reduce the levels of plasma AGEs in women with polycystic ovary syndrome after 6 months of treatment [32]. Therefore, it is valuable to investigate the AGE lowering effect of these therapies in MS patients. Eventually, results from these clinical trials could lead to add-on therapies for MS patients.

\section{Translational capacity of the animal model}

The research conducted in this thesis used the EAE model. This model is induced by the sensitization to myelin peptides, such as myelin oligodendrocyte glycoprotein (MOG). To boost the immune system, mice are injected with pertussis toxin following sensitization. This results in paralysis of the tail which gradually expends towards the front legs [33, 34]. In the EAE model we see infiltration of immune cells, demyelination and remyelination, which is comparable to the processes seen in MS patients [35]. However, MS is a complex heterogeneous disease in which genetic and environmental factors play an important role. It is therefore difficult to capture all of these aspects in one animal model [36]. Moreover, an important difference between the EAE model and $M S$ is that in the EAE model the trigger for the disease is known. The EAE model is commonly used to investigate the effects of various therapies on the disease progression but this does not imply that therapies successful in the EAE 
model are successful in MS patients [37-39]. Therefore, one must be careful in the translation from animal model to the human situation.

\section{Conclusion}

The societal utilization of the findings presented in this thesis are for the distant future as clinical trials are needed to elucidate whether lowering AGEs is beneficial for MS patients. This will require time to set-up clinical trials including a long follow-up time and analysis of the data. The results of these clinical trials could be easily implemented in the life of MS patients as it requires lifestyle changes or the addition of a therapeutic. Dieticians could coach and help MS patients to make the dietary changes. Beneficial outcome of AGE lowering on disease progression, number of relapses and patient wellbeing could eventually result in less hospitalizations and lower health care costs as a result. Ultimately, this will contribute to a better quality of life for MS patients. 


\section{References}

1. Ellwardt, E. and F. Zipp, Molecular mechanisms linking neuroinflammation and neurodegeneration in MS. Exp Neurol, 2014. 262 Pt A: p. 8-17.

2. MS Prevalence. [cited 201816 November]; Available from: https://www.nationalmssociety.org/About-the-Society/MS-Prevalence.

3. Kramer, M.A., et al., Incidence of multiple sclerosis in the general population in the Netherlands, 1996-2008. Neuroepidemiology, 2012. 39(2): p. 96-102.

4. Uitdehaag, B., et al., New insights into the burden and costs of multiple sclerosis in Europe: Results for the Netherlands. Mult Scler, 2017. 23(2_suppl): p. 117129.

5. van Ooteghem, P., et al., Prevalence of multiple sclerosis in Flanders, Belgium. Neuroepidemiology, 1994. 13(5): p. 220-5.

6. Multiple sclerosis: the disease. [cited 20185 December]; Available from: https://www.fondation-charcot.org/en/multiple-sclerosis-disease.

7. Patti, F. and C. Vila, Symptoms, prevalence and impact of multiple sclerosis in younger patients: a multinational survey. Neuroepidemiology, 2014. 42(4): p. 211-8.

8. Buljevac, D., et al., Prospective study on the relationship between infections and multiple sclerosis exacerbations. Brain, 2002. 125(Pt 5): p. 952-60.

9. Wijnands, J.M., et al., Infection-related health care utilization among people with and without multiple sclerosis. Mult Scler, 2017. 23(11): p. 1506-1516.

10. Torkildsen, O., K.M. Myhr, and L. Bo, Disease-modifying treatments for multiple sclerosis - a review of approved medications. Eur J Neurol, 2016. 23 Suppl 1: p. 18-27.

11. Gaens, K.H.J., et al., N-epsilon-(Carboxymethyl) lysine-Receptor for Advanced Glycation End Product Axis Is a Key Modulator of Obesity-Induced Dysregulation of Adipokine Expression and Insulin Resistance. Arteriosclerosis Thrombosis and Vascular Biology, 2014. 34(6): p. 1199-1208.

12. Hanssen, N.M., et al., Higher levels of advanced glycation endproducts in human carotid atherosclerotic plaques are associated with a rupture-prone phenotype. Eur Heart J, 2014. 35(17): p. 1137-46.

13. Stitt, A.W., et al., Advanced glycation end products (AGES) co-localize with AGE receptors in the retinal vasculature of diabetic and of AGE-infused rats. Am J Pathol, 1997. 150(2): p. 523-31.

14. van Eupen, M.G., et al., The methylglyoxal-derived AGE tetrahydropyrimidine is increased in plasma of individuals with type 1 diabetes mellitus and in atherosclerotic lesions and is associated with SVCAM-1. Diabetologia, 2013. 56(8): p. 1845-55.

15. Polman, C.H., et al., Diagnostic criteria for multiple sclerosis: 2010 revisions to the McDonald criteria. Ann Neurol, 2011. 69(2): p. 292-302.

16. Grytten, N., O. Torkildsen, and K.M. Myhr, Time trends in the incidence and prevalence of multiple sclerosis in Norway during eight decades. Acta Neurol Scand, 2015. 132(199): p. 29-36.

17. Scheijen, J., et al., Analysis of advanced glycation endproducts in selected food items by ultra-performance liquid chromatography tandem mass spectrometry: Presentation of a dietary AGE database. Food Chem, 2016. 190: p. 1145-1150.

18. Laursen, J.H., et al., Vitamin $D$ supplementation reduces relapse rate in relapsingremitting multiple sclerosis patients treated with natalizumab. Mult Scler Relat Disord, 2016. 10: p. 169-173.

19. N, A.L. and F. Carbonero, Impact of Maillard reaction products on nutrition and health: Current knowledge and need to understand their fate in the human digestive system. Crit Rev Food Sci Nutr, 2017: p. 1-14.

20. Uribarri, J., et al., Advanced glycation end products in foods and a practical guide to their reduction in the diet. J Am Diet Assoc, 2010. 110(6): p. 911-16 e12.

21. Voziyan, P.A. and B.G. Hudson, Pyridoxamine: the many virtues of a maillard reaction inhibitor. Ann N Y Acad Sci, 2005. 1043: p. 807-16. 
22. Itokawa, M., et al., Pyridoxamine: A novel treatment for schizophrenia with enhanced carbonyl stress. Psychiatry Clin Neurosci, 2018. 72(1): p. 35-44.

23. Garg, S., A. Syngle, and K. Vohra, Efficacy and tolerability of advanced glycation end-products inhibitor in osteoarthritis: a randomized, double-blind, placebocontrolled study. Clin J Pain, 2013. 29(8): p. 717-24.

24. Williams, M.E., et al., Effects of pyridoxamine in combined phase 2 studies of patients with type 1 and type 2 diabetes and overt nephropathy. Am J Nephrol, 2007. 27(6): p. 605-14.

25. Maessen, D.E., et al., Delayed Intervention With Pyridoxamine Improves Metabolic Function and Prevents Adipose Tissue Inflammation and Insulin Resistance in High-Fat Diet-Induced Obese Mice. Diabetes, 2016. 65(4): p. 95666.

26. Sakurai, T., et al., Absorption and metabolism of pyridoxamine in mice. I. Pyridoxal as the only form of transport in blood. J Nutr Sci Vitaminol (Tokyo), 1991. 37(4): p. 341-8.

27. Sakurai, T., et al., Absorption and metabolism of pyridoxamine in mice. II. Transformation of pyridoxamine to pyridoxal in intestinal tissues. J Nutr Sci Vitaminol (Tokyo), 1992. 38(3): p. 227-33.

28. Bolton, W.K., et al., Randomized trial of an inhibitor of formation of advanced glycation end products in diabetic nephropathy. Am J Nephrol, 2004. 24(1): p. 32-40.

29. Sell, D.R. and V.M. Monnier, Molecular basis of arterial stiffening: role of glycation - a mini-review. Gerontology, 2012. 58(3): p. 227-37.

30. Ruggiero-Lopez, D., et al., Reaction of metformin with dicarbonyl compounds. Possible implication in the inhibition of advanced glycation end product formation. Biochem Pharmacol, 1999. 58(11): p. 1765-73.

31. Bakris, G.L., et al., Advanced glycation end-product cross-link breakers. A novel approach to cardiovascular pathologies related to the aging process. Am J Hypertens, 2004. 17(12 Pt 2): p. 23S-30S.

32. Diamanti-Kandarakis, E., et al., Effect of metformin administration on plasma advanced glycation end product levels in women with polycystic ovary syndrome. Metabolism, 2007. 56(1): p. 129-34.

33. Batoulis, H., et al., Experimental autoimmune encephalomyelitis--achievements and prospective advances. APMIS, 2011. 119(12): p. 819-30.

34. Rangachari, M. and V.K. Kuchroo, Using EAE to better understand principles of immune function and autoimmune pathology. J Autoimmun, 2013. 45: p. 31-9.

35. Baxter, A.G., The origin and application of experimental autoimmune encephalomyelitis. Nat Rev Immunol, 2007. 7(11): p. 904-12.

36. Procaccini, C., et al., Animal models of Multiple Sclerosis. Eur J Pharmacol, 2015. 759: p. 182-91.

37. van Oosten, B.W., et al., Increased MRI activity and immune activation in two multiple sclerosis patients treated with the monoclonal anti-tumor necrosis factor antibody CA2. Neurology, 1996. 47(6): p. 1531-4.

38. Wiendl, H. and R. Hohlfeld, Therapeutic approaches in multiple sclerosis: lessons from failed and interrupted treatment trials. BioDrugs, 2002. 16(3): p. 183-200.

39. Hunig, T., Manipulation of regulatory T-cell number and function with CD28specific monoclonal antibodies. Adv Immunol, 2007. 95: p. 111-48. 



\section{Curriculum Vitae}


Suzan Wetzels was born on $12^{\text {th }}$ of July 1991 in Heerlen. She graduated from secondary school (VWO, Eijkhagen College in Landgraaf) in 2009. In September 2009, she started with her bachelor study Biomedical Sciences, specialization Molecular Life Sciences, at Maastricht University. Her bachelor's degree was followed with the master Biomedical Sciences, specialization Cardiovascular Biology and Medicine. In 2014, she received her master's degree with distinction. Her senior internship was performed at the department of Internal Medicine under the supervision of dr. Kristiaan Wouters, dr. Katrien Gaens and dr. Marleen van Greevenbroek which resulted in the thesis entitled: Novel players in monocyte attraction and macrophage activation in adipose tissue during obesity. The data generated during her senior internship were selected to be presented by means of a poster presentation during the meeting of the European Association for the Study of Diabetes (EASD) in September 2014 in Vienna, Austria.

In September 2014 she started a joint PhD project between Maastricht University and Hasselt University. This PhD project was conducted under the supervision of Prof. dr. Casper Schalkwijk (Maastricht University) and Prof. dr. Jerome Hendriks (Hasselt University), and dr. Kristiaan Wouters (Maastricht University) and dr. Tim Vanmierlo (Hasselt University). During her PhD, Suzan studied the role of advanced glycation endproducts in multiple sclerosis. The results of her research are presented in this thesis. 


\section{Scientific output}




\section{Publications}

\section{Publications from this work}

Methylglyoxal-derived advanced glycation endproducts in multiple sclerosis.

Wetzels S., Wouters K., Schalkwijk C.G., Vanmierlo T.*, Hendriks J.J.A.* Int J Mol Sci. 2017 Feb 15;18(2)

Advanced glycation endproducts are increased in the animal model of multiple sclerosis but cannot be reduced by pyridoxamine treatment or glyoxalase 1 overexpression.

Wetzels S., Wouters K., Miyata T., Scheijen J.L.J.M., Hendriks J.J.A., Schalkwijk C.G.*, Vanmierlo T.*

Int J Mol Sci. 2018 Apr 27;19(5)

Methylglyoxal-derived advanced glycation endproducts accumulate in multiple sclerosis lesions.

Wetzels S., Vanmierlo T., Scheijen J.L.J.M., Van Horssen J., Amor S., Somers V., Schalkwijk C.G., Hendriks J.J.A.*, Wouters K.*

Submitted to Frontiers in Immunology, special edition: Multiple sclerosis and neuroimmunology

*equal contribution

\section{Publications in collaboration}

Characterization of immune cells in human adipose tissue by using flow cytometry.

Wetzels S.*, Bijnen M.*, Wijnands E., Biessen E.A.L., Schalkwijk C.G., Wouters $\mathrm{K}$.

J Vis Exp. 2018 Mar 6;(133).

Circulating classical monocytes are associated with $\mathrm{CD}_{11} \mathrm{c}^{+}$macrophages in human visceral adipose tissue.

Wouters K., Gaens K., Bijnen M., Verboven K., Jocken J., Wetzels S., Wijnands E., Hansen D., van Greevenbroek M., Duijvestijn A., Biessen E.A.L, Blaak E.E., Stehouwer C.D., Schalkwijk C.G.

Sci Rep. 2017 Feb 15; 7:42665

Abdominal subcutaneous and visceral adipocyte size, lipolysis and inflammation relate to insulin resistance in male obese humans.

Verboven K., Wouters K., Gaens K., Hansen D., Bijnen M., Wetzels S., Stehouwer C.D., Goossens G.H., Schalkwijk C.G., Blaak E.E., Jocken J.W.

Sci Rep. 2018 Mar 16;8(1):4677 
RAGE deficiency does not affect non-alcoholic steatohepatitis and atherosclerosis in Western type diet-fed LdIr $^{-/-}$mice.

Bijnen M., Beelen N., Wetzels S., van de Gaar J., Vroomen M., Wijnands E., Scheijen J.L.J.M., van de Waarenburg M.P.H., Gijbels M.J., Cleutjens J.P., Biessen E.A.L., Stehouwer C.D.A., Schalkwijk C.G., Wouters K.

Sci Rep. 2018 Oct 15;8(1):15256

NK cells in human visceral adipose tissue contribute to obesity-associated insulin resistance through macrophage polarization and low-grade inflammation.

Wouters $\mathrm{K} *$, Kusters Y.H.A.M *, Bijnen M., Wetzels S., Linssen P.B.C., Gaens K., Houben A.J.H.M., Joris P., Plat J., Kooi E., van der Kallen C.J.H., Mensink R.P., Verboven K. Jocken J., Hansen D., Blaak E.E., Stehouwer C.D.A., Schalkwijk C.G.

Revision invited by Cell Metabolism

*Equal contribution 


\section{Presentations}

\section{Oral presentations}

Advanced glycation endproducts in the brain of multiple sclerosis patients.

Wetzels S., Wouters K., Vanmierlo T., Scheijen J.L.J.M., van de Waarenburg M., Schalkwijk C.G., Hendriks J.J.A.

MS Research Days - 17-11-2016 and 18-11-2016, Amsterdam, the Netherlands

The formation of advanced glycation endproducts in the central nervous system of MS patients and its animal model EAE.

Wetzels S., Wouters K., Vanmierlo T., Scheijen J.L.J.M., van de Waarenburg M., Schalkwijk C.G., Hendriks J.J.A.

MS Research Days - 15-11-2017 and 16-11-2017, Tiel, the Netherlands

\section{Poster presentations}

Advanced glycation endproducts are increased in the spinal cord and brain of mice with experimental autoimmune encephalomyelitis.

Wetzels S., Wouters K., Vanmierlo T., Scheijen J.L.J.M., van de Waarenburg M., Schalkwijk C.G., Hendriks J.J.A.

FWO-WOG-Multiple Sclerosis Symposium - 25-03-2016, Gent, Belgium.

Advanced glycation endproducts in the brain of multiple sclerosis patients.

Wetzels S., Wouters K., Vanmierlo T., Scheijen J.L.J.M., van de Waarenburg M., Schalkwijk C.G., Hendriks J.J.A.

- $\quad$ tUL Research day - 5-10-2016, Bilzen, Belgium

- Microglia Meeting - 20-04-2017 \& 21-04-2017, Groningen, the Netherlands

The formation of advanced glycation endproducts in the central nervous system of MS patients and its animal model EAE.

Wetzels S., Wouters K., Vanmierlo T., Scheijen J.L.J.M., van de Waarenburg M., Schalkwijk C.G., Hendriks J.J.A.

- FWO-WOG-Multiple Sclerosis Symposium - 24-10-2017, Hasselt, Belgium

- $\quad$ Autoimmunity - Celebrating the network - 25-05-2018, Hasselt, Belgium 
Dankwoord 
Het zit erop! De afgelopen vier jaar zijn voorbij gevlogen. Ik heb met ontzettend veel plezier in zowel Maastricht als Hasselt gewerkt. Dit resulteerde in een grote groep fijne collega's waar ik veel van heb geleerd. Dit proefschrift was er niet gekomen zonder de hulp van velen. Daarom wil ik iedereen die een bijdrage heeft geleverd aan het tot stand komen van mijn proefschrift, in welke vorm dan ook, bedanken!

Als eerste een woord van dank aan mijn promotoren: Prof. dr. Casper Schalkwijk en Prof. dr. Jerome Hendriks. Beste Casper en Jerome, als eerste wil ik jullie bedanken voor de mogelijkheid om dit joint PhD-project uit te voeren in jullie groepen en het avontuur samen aan te gaan! Het voordeel van een gezamenlijk project is dat je de gelegenheid krijgt om op twee diverse afdelingen te werken en je een scala aan technieken eigen te maken. Niet te vergeten dat je ook een dubbele hoeveelheid aan input en ideeën krijgt vanuit ieders eigen perspectief en werkveld. Dat is zeker een grote meerwaarde voor het project geweest. Ik heb hier zelf ook ontzettend veel van geleerd en ben hierdoor gegroeid als onderzoeker. Casper, de ontspannen sfeer op de afdeling is fantastisch. Dit zorgt ervoor dat ik me thuis heb gevoeld en deel van het team, ondanks dat ik er maar de helft van de week was. Bedankt voor jouw positieve blik op mijn resultaten, zelfs als ik het zelf even niet meer zag. Daarbij ook bedankt voor de gezellige kerst-etentjes en lab-uitjes. Aangezien ik afgelopen jaar bij jou in het team zat, was ook ik eens verzekerd van de winst! Jerome, de andere helft van de week was ik te vinden op Biomed. Ondanks dat ik onderzoek deed naar AGEs, werd ik met een warm welkom ontvangen in de groep. Bedankt voor jouw feedback op mijn manuscripten, waardoor de puntjes op de i werden gezet. Daarbij ook bedankt voor de gezellige lab-drinks/etentjes, de dagen in Brugge en het lasergamen met het team. Ik geloof wel dat we nog eens revanche moeten nemen op de T-cel-groep!

Vervolgens mijn copromotoren: Dr. Kristiaan Wouters en Dr. Tim Vanmierlo. Beste Kristiaan en Tim, het vertrouwen dat jullie in mij hebben, werkt ontzettend motiverend en stimulerend! Het heeft me de gelegenheid gegeven om me te ontwikkelen als onderzoeker. Jullie voorzagen de meest ruwe versie van mijn manuscripten van feedback, voordat de bijgeschaafde versie naar Casper en Jerome ging. Heel erg bedankt voor al jullie hulp de afgelopen jaren! Daarbij werkt jullie enthousiasme over wielrennen ook erg aanstekelijk. Helaas ben ik nog niet zover dat ik ook echt op de fiets naar het werk kom, maar ik heb me voorgenomen om me hier toch eens aan te wagen... als het weer wat warmer wordt! Kristiaan, van stagebegeleider werd je mijn copromotor. Je staat altijd klaar met ideeën en suggesties voor mijn onderzoek. Ik heb ontzettend veel van jou geleerd, niet alleen over onderzoek doen maar ook over welk type onderzoeker ik wil zijn. Bedankt voor alle hulp, maar zeker ook voor de wijze raad de afgelopen jaren! Tim, jouw enthousiasme zorgde ervoor dat ik weer oppepte als de resultaten tegenvielen en niet waren warop we hadden gehoopt. Jouw deur stond altijd open om vragen te stellen of om even bij te 
praten; dat was allemaal geen probleem. Merci voor alle hulp als ook de enthousiaste nieuwe ideeën voor mijn project!

Daarnaast wil ik ook jullie partners, Hermine, Leen, Ellen en Evy graag bedanken. Ik kreeg regelmatig mailtjes met feedback in het weekend, wat betekent dat er in die tijd ook gewerkt werd en er dus minder tijd over was voor het "thuisfront". Daarbij wil ik jullie ook hartelijk danken voor jullie gastvrijheid tijdens de lab-uitjes, BBQ's en andere etentjes!

Graag wil ik de leden van de beoordelingscommissie, Prof. dr. J. Prickaerts, Prof. dr. E.A.L. Biessen, Prof. dr. V. Bito, dr. A-M van Dam, Prof. Dr. N. Hellings en Prof. dr. H. Niessen bedanken voor het beoordelen van dit proefschrift.

Ik wil ook mijn paranimfen, José en Vicky bedanken. José, menig uurtje hebben we samen op het lab doorgebracht, waarvan een deel bestond uit opofferingen. Jouw jarenlange ervaring en harde werken zorgen ervoor dat zo'n dag vloeiend en efficiënt verloopt! Naast het samenwerken op het lab, kan ik ook altijd even binnen springen om te kletsen of om advies te vragen. Ik vind het een eer dat jij naast mij wilt staan tijdens mijn promotie; een stukje van de Gaar-geschiedenis dat geschreven wordt! Vicky, als kamergenoten hebben we veel tijd samen doorgebracht. Dankjewel voor jouw hulp op het lab, maar zeker ook voor alle steun en een luisterend oor. We kunnen over alles kletsen, zowel over werk als niet-werk gerelateerde onderwerpen. Je staat voor me klaar en ik kan altijd rekenen op hulp en advies. Ik vind het super dat je tijdens mijn promotie naast mij wilt staan.

Tevens wil ik alle mensen bedanken waarmee ik de afgelopen vier jaar heb samengewerkt en die input hebben gegeven voor mijn project. Prof. dr. J. van Horssen, beste Jack, bedankt voor het beoordelen van mijn kleuringen. Prof. dr. S. Amor, dear Sandra, thank you for the samples which I obtained from your lab. Prof. T. Miyata kindly provided the pyridoxamine and Glo1 transgenic mice for the experiments, for which many thanks.

De afgelopen vier jaar heb ik met heel veel plezier gewerkt en dat is mede te danken aan de vele fijne collega's! Te beginnen in Maastricht: het grootste gedeelte van de tijd heb ik bij Petra, Vicky en Margee op de kamer gezeten. Als PhD-student op de analisten-kamer; dat was altijd gezellig met het bijkomende voordeel dat de hulpbronnen binnen handbereik waren! Dames, ik wil jullie bedanken voor de fijne tijd samen op de kamer, alle adviezen, hulp, steun en gezellige momenten. Petra, jouw optimisme werkt aanstekelijk. Ik kon bij jouw altijd terecht met mijn vragen over uiteenlopende zaken; van experimenten tot alles wat komt kijken bij een promotie. Heel erg bedankt hiervoor! Margee, ik wil je bedanken voor alle hulp op het lab. Je hebt voor mij metingen gedaan zodat ik me kon focussen op de experimenten in Hasselt of mijn proefschrift, waarvoor bedankt. Wenjie, also one of my roommates in 
Maastricht! I saw you already analyse a lot of retinas the last years. Good luck with your project! Mitchell, ik zou bijna kunnen zeggen, partner-in-crime. We zijn allebei op hetzelfde moment begonnen met onze PhD en mogen deze dan ook op ongeveer hetzelfde moment verdedigen (op die 24 uur kijken we niet..). Bedankt voor de extra hulp wanneer ik in Hasselt zat en er in Maastricht iets geregeld moest worden. Ook bedankt voor de gezellige tijd op het lab en jouw droge humor; ik heb ervan genoten! Maria, jij bent voor mij de koningin van de immunohistochemie! Je hebt me veel geholpen met het snijden van coupes en de kleuringen. Ik was ook altijd welkom voor een praatje en daar heb ik dankbaar gebruik van gemaakt; dat was heel fijn! Bedankt voor al jouw hulp en advies de afgelopen jaren. Nynke, ik heb met veel plezier meegedaan aan de kleine pilot experimentjes van jouw fructose-studie. Heel veel succes met het afronden van jouw PhD-project en met de komst van jullie kleintje. Ying, you have become an expert in SPSS which I admire. Good luck with the final part of your PhD. Marleen, je bent een vraagbaak als het over statistiek gaat. Bedankt voor de adviezen omtrent de statistiek die ik heb toegepast bij de analyse van mijn experimenten. Jean, de expert op het gebied van AGE- en a-dicarbonyl metingen in welk weefsel dan ook! Samen met Marjo hebben jullie ontzettend veel metingen gedaan die allemaal terecht zijn gekomen in dit proefschrift, waarvoor hartelijk dank. Mathias, ik ben ontzettend benieuwd naar de resultaten van jouw klinische studie. Heel veel succes met het afronden ervan. Armand, ik vind het super dat jij, na je stage bij ons, bent begonnen als AIO. Heel veel succes met jouw project! Katrien, van stagebegeleider naar collega! Bedankt voor jouw interesse in mijn onderzoek en de gezellige gesprekjes. Xiaodi, you started with your PhD project as I left so we did not work together unfortunately. Good luck with your project, but I am sure you will do great! Ad, tegenwoordig geniet je van jouw welverdiende pensioen. De afgelopen jaren zijn we elkaar regelmatig op de gang tegen gekomen en was je altijd in voor een praatje om te vragen hoe het met mijn project ging. Bedankt voor jouw interesse in mijn onderzoek. Annemieke, we komen elkaar niet veel tegen op de afdeling omdat je zo betrokken bent bij het onderwijs. Desalniettemin was het altijd gezellig om elkaar te spreken. Heel veel succes! Tate, you have mastered the vascular experiments fast, which I think is impressive. Thank you for your help with the sacrifice in Hasselt. Lots of luck with your PhD-project. Kim, bedankt voor jouw vrolijkheid op het lab en de interesse in mijn project. Succes met jouw onderzoek! Boy, altijd in voor een praatje en de vraag "hoe is het met jouw proefschrift?". Bedankt voor de interesse in mijn onderzoek. Evelien en Ine, op de valreep zijn we nog even collega's geweest. Bedankt voor de gezellige momenten tijdens de lunch en veel succes met jullie projecten. Amée, veel succes met jouw onderzoek. Nordin, jouw enthousiasme voor het onderzoek is bewonderingswaardig en ik heb met veel plezier samengewerkt. Succes in de kliniek maar ook met jouw onderzoek. Erwin, ondanks dat we in mijn project geen gebruik hebben gemaakt van de FACS hebben we toch regelmatig samengewerkt. Bedankt voor de gezellige tijd! Er zijn ook veel collega's waarmee ik de afgelopen jaren heb samengewerkt maar die 
ondertussen al aan nieuwe avonturen zijn begonnen: Dionne, Monica, Dennis, Thomas, Stijn, Yvo, Lian, Marcelle, Elisabeth, Olaf, Hanneke en Pauline; bedankt voor de gezellige tijd bij Interne Geneeskunde.

Vervolgens door naar de gezellige collega's van Hasselt: Winde, merci voor het wegwijs maken op Biomed. Ik zal de eet-middagen op het bureau niet snel vergeten waarbij de spreuk "hap hap macrofaagjes" centraal stond. Jo, ik heb soms medelijden met jou gehad; als enige man op een kamer vol dames, dat kan niet altijd makkelijk zijn geweest. Je was mijn hulp als ik in de knoop zat met mijn laptop/programma's. Merci voor de fijne tijd op Biomed. Jasmine, bedankt voor al jouw hulp bij mijn dierexperimenten maar zeker ook de gezellige middagen op het bureau met heel veel theetjes. Elien W., mijn maatje als het om celkweek gaat maar ook om even thee te drinken en te kletsen. Merci voor alle assistentie bij mijn experimenten. Ik bewonder jouw gedrevenheid in het onderzoek! Heel veel succes met het afronden van jouw doctoraat. Elien G., van master student uitgegroeid tot AIO in onze groep. Samen met Jeroen hebben jullie een mooi project lopen. Veel succes hiermee. Tess, wat ben jij een heerlijk vrolijk persoon. Bedankt voor de gezellige tijd en veel succes met jouw onderzoek. Aida, good luck with your PhD-project! Jeroen, bedankt voor jouw belangstelling in mijn onderzoek. Katrien, merci voor de hulp bij de inducties van de EAE en bij het beantwoorden van al mijn vragen over fluorescente dubbelkleuringen. Veronique, een dikke merci voor alle hulp met het administratieve aspect van mijn doctoraat! Daarnaast wil ik alle andere collega's op Biomed bedanken voor de fijne tijd!

Na mijn promotietraject ben ik aan de slag gegaan bij de vakgroep Pathologie bij het MUMC+ in Maastricht. Ik wil alle collega's van de Pathologie bedanken voor het warme welkom.

Naast promoveren is het ook nodig om te ontspannen. En dat ontspannen, je hoofd helemaal leegmaken of juist ideeën krijgen, gebeurde vaak tijdens het sporten. Marlies en Léon bedankt voor de heerlijke uren sporten onder jullie begeleiding!

De afgelopen jaren was donderdagavond bij SalsAddicts vaste prik. Samen met Kay, Linda, Paul, Saran, Roelof en alle andere SalsAddicts cursisten heb ik mijn Cubaanse salsapasjes oneindig vaak geoefend. Jullie hadden altijd interesse in mijn onderzoek en vroegen geregeld hoe het ermee was. Dankjewel voor alle dansplezier en voor jullie belangstelling.

Bij ontspanning hoort ook onze grote vriendin Linn, en natuurlijk haar baasjes Roy en Jenna. Ik wil jullie bedanken voor jullie interesse in mijn onderzoek, de gezellig avondjes en de BBQ's samen met jullie kids!

De dames van de cocktail-avondjes: Manon, Bianca, Vivian en Linda. Tegenwoordig is het meer thee dan cocktails drinken, maar desalniettemin is het 
altijd even gezellig! Bedankt voor de vele uurtjes gezelligheid, het kletsen over de reizen die we gemaakt hebben of graag willen maken en over het voorbereiden van een bruiloft!

Jasmine en Elien, van collega's zijn we vriendinnen geworden! Ondanks dat we ieder onze eigen weg zijn gegaan qua werk, zorgen we ervoor dat we elkaar geregeld zien. Dat gaat dan samen met grote hoeveelheden thee, eten en heel veel geklets. Bij jullie kan ik altijd mijn verhaal doen en jullie staan altijd voor me klaar! Heel erg bedankt hiervoor!

Lieve familie, bedankt voor jullie belangstelling in mijn onderzoek, de steun en alle gezellige momenten samen. In het bijzonder een dankjewel aan Opa en Oma; ik weet dat jullie trots op ons zijn!

Marianne en Jan, bedankt voor jullie interesse in mijn promotieproject de afgelopen jaren! Tevens bedankt voor de vele gezellige etentjes, samen met Joëlle en Roger, waarbij we het voor elkaar krijgen om steeds op dezelfde gespreksonderwerpen terug komen! Joëlle en Roger, jullie wil ik ook bedanken voor de gezellige middagen in de zon op het terras bij d'r Eck onder het genot van een Neubourg en een Kriek. Lieve Tom, Sam en Fem, de boefjes van tante Suus; samen op de trampoline, naar de film, paaseieren zoeken bij opa en oma of logeerpartijtjes, ik geniet er ontzettend van.

Lieve papa en mama, zonder jullie was dit boekje er niet geweest. Jullie hebben Tom en mij alle kansen gegeven zodat wij ons konden ontwikkelen en zijn geworden wie we nu zijn. Jullie hebben ons geleerd om niet bij de pakken neer te zitten wanneer het moeilijk is maar om er met volle overtuiging voor te gaan en er alles uit te halen! Ik ben ongelofelijk trots op jullie! Bedankt voor jullie steun en de peptalks als het even tegenzat. Ohne Worte!

Lieve Tom en Manon, dankjewel voor de gezellige, spontane momenten samen! Tom, ik geniet van jouw droge humor en de manier hoe je me, samen met Dion, binnen 3 seconden op de kast kunt krijgen. Jullie zijn hierin een echt topteam! Wanneer we met $z^{\prime} n$ zessen bij papa en mama thuis zijn, gezellig kletsend aan tafel, realiseer ik me des te meer wat een fijn hecht gezin we zijn!

Lieve Dion, je hebt heel vaak gezegd dat je helemaal niet in het dankwoord wilde staan want daar zag je het nut niet van in. Maar zoals je ziet, sta je er toch! Want ik wil je bedanken voor alles wat je voor me doet. Je bent mijn grote voorbeeld, weet als geen ander de dingen te relativeren en mij te kalmeren. De afgelopen jaren waren niet altijd even makkelijk, maar jij bent mijn grote steun geweest en ik weet dat wij samen alles aankunnen. Ik kijk uit naar de nieuwe avonturen die we samen tegemoet gaan! 


\section{Abbreviations}




$\begin{array}{ll}\text { 3DG } & \text { 3-deoxyglucosone } \\ \text { AG } & \text { Aminoguanidine } \\ \text { AGER1 } & \text { Advanced glycation receptor 1 } \\ \text { AGEs } & \text { Advanced glycation endproducts } \\ \text { AHSCT } & \text { Autologous hematopoietic stem cell transplantation } \\ \text { ALES } & \text { Advanced lipoxidation endproducts } \\ \text { ANOVA } & \text { Analysis of variance } \\ \text { AUC } & \text { Area under the curve } \\ \text { BBB } & \text { Blood-brain barrier } \\ \text { BMDMs } & \text { Bone marrow-derived macrophages } \\ \text { CD } & \text { Cluster of differentiation } \\ \text { CDNA } & \text { Complementary DNA } \\ \text { CEL } & \text { N }{ }^{\varepsilon} \text {-(1-carboxyethyl)lysine } \\ \text { CFA } & \text { Complete Freund's adjuvant } \\ \text { CIS } & \text { Clinical isolated syndrome } \\ \text { CML } & \text { N }{ }^{\varepsilon} \text {-(carboxymethyl)lysine } \\ \text { CNS } & \text { Central nervous system } \\ \text { CSF } & \text { Cerebrospinal fluid } \\ \text { CyCA } & \text { Cyclophilin A } \\ \text { DHAP } & \text { Dihydroxyacetone phosphate } \\ \text { DMT } & \text { Disease-modifying therapies } \\ \text { DNA } & \text { Deoxyribonucleic acid } \\ \text { EAE } & \text { Experimental autoimmune encephalomyelitis } \\ \text { EDSS } & \text { Expanded disability status scale } \\ \text { EPs } & \text { Evoked potentials } \\ \text { FDA } & \text { Food and drugs administration } \\ \text { GAP } & \text { Glyceraldehyde-3-phosphate } \\ \text { GFAP } & \text { Glial fibrillary acidic protein } \\ \text { Glo } & \text { Glyoxalase } \\ \text { Glut } & \text { Glucose transporter } \\ \text { GO } & \text { Glyoxal } \\ \text { GSH } & \text { Reduced glutathione } \\ \text { GSSH } & \text { Oxidized glutathione } \\ \text { GWAS } & \text { Genome-wide association studies } \\ \text { H2O } & \text { Hydrogen peroxide } \\ \text { HLA } & \text { Human leukocyte antigen } \\ \text { HMGB } & \text { High mobility group box } \\ & \end{array}$




$\begin{array}{ll}\text { HNE } & \text { 4-hydroxynonenal } \\ \text { IFN } \beta & \text { Interferon } \beta \\ \text { IgG } & \text { Immunoglobulin G } \\ \text { IL } & \text { Interleukin } \\ \text { LPS } & \text { Lipopolysaccharide } \\ \text { MBP } & \text { Myelin basic protein } \\ \text { MCP1 } & \text { Monocyte chemotactic protein 1 } \\ \text { MDA } & \text { Malondialdehyde } \\ \text { MG-BSA } & \text { MGO modified bovine serum albumin } \\ \text { MG-H1 } & \text { No-(5-hydro-5-methyl-4-imidazolon-2-yl)-ornithine } \\ \text { MGO } & \text { Methylglyoxal } \\ \text { MHC } & \text { Major histocompatibility complex } \\ \text { MMPs } & \text { Matrix metalloproteinases } \\ \text { MOG } & \text { Myelin oligodendrocyte glycoprotein } \\ \text { MRI } & \text { Magnetic resonance imaging } \\ \text { mRNA } & \text { Messenger ribonucleic acid } \\ \text { MS } & \text { Multiple sclerosis } \\ \text { NAWM } & \text { Normal appearing white matter } \\ \text { NDCs } & \text { Non-demented controls } \\ \text { NF } & \text { Neurofilament } \\ \text { NF-KB } & \text { Nuclear factor kappa B } \\ \text { O }{ }^{-} & \text {Superoxide } \\ \text { ONOO- } & \text { Peroxynitrite } \\ \text { PB } & \text { Protein-bound } \\ \text { PGK-1 } & \text { Phosphoglycerate kinase 1 } \\ \text { PLP } & \text { Proteolipid protein } \\ \text { PM } & \text { Pyridoxamine } \\ \text { PMD } & \text { Post-mortem delay } \\ \text { PP-MS } & \text { Primary progressive MS } \\ \text { qPCR } & \text { Quantitative real-time polymerase chain reaction } \\ \text { RAGE } & \text { Receptor for advanced glycation endproducts } \\ \text { ROS } & \text { Reactive oxygen species } \\ \text { RR-MS } & \text { Relapsing remitting MS } \\ \text { SAF } & \text { Skin autofluorescence } \\ \text { SD } & \text { Standard deviation } \\ \text { SEM } & \text { Standard error of the mean } \\ \text { Sirt1 } & \text { Sirtuin 1 } \\ & \end{array}$


SP-MS Secondary progressive MS

sRAGE soluble RAGE

THP Tetrahydropyrimidine

TNFa Tumor necrosis factor a

UPLC MSMS Ultra-performance liquid chromatography tandem mass

WT Wild type 